\title{
The evolution of Earth's biogeochemical nitrogen cycle
}

\author{
Eva E. Stüeken ${ }^{1,2,3 *}$, Michael A. Kipp ${ }^{1}$, Matthew C. Koehler $^{1}$, Roger Buick ${ }^{1}$
}

1. Department of Earth \& Space Sciences and Astrobiology Program, University of Washington, Seattle, WA 98195-1310, USA

2. Department of Earth Sciences, University of California, Riverside, CA 92521, USA

3. Department of Earth \& Environmental Sciences, University of St Andrews, St Andrews KY16 9AL, Scotland, UK

* evast@uw.edu

\begin{abstract}
Nitrogen is an essential nutrient for all life on Earth and it acts as a major control on biological productivity in the modern ocean. Accurate reconstructions of the evolution of life over the course of the last four billion years therefore demand a better understanding of nitrogen bioavailability and speciation through time. The biogeochemical nitrogen cycle has evidently been closely tied to the redox state of the ocean and atmosphere. Multiple lines of evidence indicate that the Earth's surface has passed in a non-linear fashion from an anoxic state in the Hadean to an oxic state in the later Phanerozoic. It is therefore likely that the nitrogen cycle has changed markedly over time, with potentially severe implications for the productivity and evolution of the biosphere. Here we compile nitrogen isotope data from the literature and review our current understanding of the evolution of the nitrogen cycle, with particular emphasis on the Precambrian. Combined with recent work on redox conditions, trace metal availability, sulfur and iron cycling on the early Earth, we then use the nitrogen isotope record as a platform to test existing and new hypotheses about biogeochemical pathways that may have controlled nitrogen availability through time. Among other things, we conclude that (a) abiotic nitrogen sources were likely insufficient to sustain a large biosphere, thus favoring an early origin of biological $\mathrm{N}_{2}$ fixation, (b) evidence of nitrate in the Neoarchean and Paleoproterozoic confirm current views of increasing surface oxygen levels at those times, (c) abundant ferrous iron and sulfide in the midPrecambrian ocean may have affected the speciation and size of the fixed nitrogen reservoir, and (d) nitrate availability alone was not a major driver of eukaryotic evolution.
\end{abstract}

\section{Keywords}

nitrogen cycle; nitrogen isotopes; Precambrian; evolution

\section{Introduction}

Nitrogen is a major nutrient that is essential to all life on Earth and it is likely that this is no accident of chemical evolution, for at least three reasons. First, it is an abundant element in the cosmos and in Earth's atmosphere (Henry et al., 2000; Marty, 2012); second, it forms versatile covalent bonds with carbon that are integral to the functioning of organic biomolecules; and third, nitrogen is redox-active in the stability field of liquid water and is thus a potent source 
of electrochemical energy for biological metabolism (Schoepp-Cothenet et al., 2012). A better understanding of what constrained the evolution of life on Earth therefore demands a reconstruction of the biogeochemical nitrogen cycle over time; in particular its role as a limiting nutrient affecting biological evolution and ecology (Anbar and Knoll, 2002).

Evolution of the nitrogen cycle may also have had significant effects on the continued habitability of the Earth. The partial pressure of nitrogen gas $\left(\mathrm{N}_{2}\right)$ in the atmosphere controls the degree of pressure-broadening of greenhouse gas adsorption and thus surface temperature (Goldblatt et al., 2009). Moreover, some nitrogenous gaseous species are powerful greenhouse gases themselves, such as nitrous oxide $\left(\mathrm{N}_{2} \mathrm{O}\right)$ and nitrogen dioxide $\left(\mathrm{NO}_{2}\right)$ (Byrne and Goldblatt, 2014). These gases can also affect climate indirectly by their role in the formation of ozone $\left(\mathrm{O}_{3}\right)$, which is a powerful greenhouse agent in the troposphere. Ammonia $\left(\mathrm{NH}_{3}\right)$ is also a potent greenhouse gas but is often neglected due to its short atmospheric residence time resulting from rapid photolytic destruction. However, if $\mathrm{NH}_{3}$ flux rates to the atmosphere are high, then this photolysis barrier can be overcome, with a resulting effect on surface temperatures (Kuhn and Atreya, 1979). Lastly, nitrogenous gas species can react with carbonaceous compounds to form aerosol hazes such as photochemical smog or organic particulates like the tholins of Titan. These have an anti-greenhouse effect and cool temperatures by physically blocking solar insolation.

The redox state of Earth's surface plays an important role in the biogeochemical nitrogen cycle because nitrogen is highly redox-active. Nitrate $\left(\mathrm{NO}_{3}{ }^{-}\right)$, the most oxidized nitrogen species $\left(\mathrm{N}^{+\mathrm{V}}\right)$, is stable under oxic conditions. Denitrification, i.e. reduction of nitrate to more reduced forms including $\mathrm{N}_{2}\left(\mathrm{~N}^{0}\right), \mathrm{N}_{2} \mathrm{O}\left(\mathrm{N}^{+1}\right)$ or $\mathrm{NH}_{4}^{+}\left(\mathrm{N}^{-\mathrm{III}}\right)$, usually occurs at a higher Eh than reduction of ferric iron and sulfate (Fig. 1). The onset of widespread nitrification - the oxidation of $\mathrm{NH}_{4}{ }^{+}$ to $\mathrm{NO}_{3}{ }^{-}$- is thus plausibly linked to the appearance of oxygenic photosynthesis and the accumulation of $\mathrm{O}_{2}$ in atmosphere and oceans. The strong redox activity further suggests that the nitrogen cycle may have been linked to iron and sulfur cycles. In their reduced form, both $\mathrm{Fe}$ and $\mathrm{S}$ could have acted as electron donors during denitrification, whereas the oxidized species may have played a role in nitrogen remineralization, but the linkages are so far unclear. Furthermore, it has been hypothesized that extensive euxinia (anoxia with dissolved $\mathrm{HS}^{-}$) may have lowered the concentration of transition metals such as $\mathrm{Mo}$ or $\mathrm{Cu}$ in the Precambrian ocean (Anbar and Knoll, 2002; Buick, 2007a). Many of these elements are essential cofactors in the nitrogen cycle and their absence could have limited nitrogen bioavailability.

Over recent years, it has become apparent that the nitrogen biogeochemical cycle has changed markedly over geological time, especially during the Archean and Proterozoic (e.g. Ader et al., 2014; Garvin et al., 2009; Godfrey and Falkowski, 2009; Koehler et al., in review; Stüeken, 2013; Stüeken et al., 2015b; Stüeken et al., 2015c). These changes apparently occurred partly in response to biological evolution and partly as a result of varying environmental conditions, particularly the redox state of the ocean and atmosphere. In this paper, we will review these key events in nitrogen-cycle evolution, concentrating on the Precambrian when the most radical changes occurred. Based on inferred trends in the evolution of the nitrogen cycle, we will revisit key questions about abiotic and biotic nitrogen fixation, nitrogen speciation in seawater and the relationship between nitrogen availability and the evolution of eukaryotes.

\section{Nitrogen and redox}

\subsection{Current working model of Earth's redox evolution}


Nitrogen is redox-sensitive in the stability field of liquid water, and therefore the oxygenation of Earth's atmosphere and oceans has played a major role in the evolution of the global biogeochemical nitrogen cycle. Constraining the history of oxygen production and accumulation in surface environments is thus required to arrive at accurate reconstructions of nitrogen speciation and bioavailability through time. The oldest possible signs of oxygenic photosynthesis date back to $3.8 \mathrm{Gyr}$ (reviewed in Buick, 2008). Recent work proposes a minimum age of 3.0 Gyr (Crowe et al., 2013; Planavsky et al., 2014a). However, prior to 2.3 Gyr, atmospheric $\mathrm{O}_{2}$ did likely not accumulate to more than $10^{-5}$ times present atmospheric levels (PAL), i.e. the threshold for mass-independent fractionation (MIF) in sulfur isotopes (Pavlov and Kasting, 2002), and it may even have been significantly lower (Kurzweil et al., 2013). Before $2.75 \mathrm{Ga}$, oxidative weathering is thought to have been trivial on a global scale (Stuieken et al., 2012) and, if present, restricted to local areas where cyanobacteria may have been thriving (Crowe et al., 2013; Lalonde and Konhauser, 2015). There are no documented occurrences of euxinia in the Paleo- and Meso-Archean, suggesting that marine sulfate concentrations were very low, possibly $<0.2 \mathrm{mM}$ (Habicht et al., 2002). This may have changed around $2.75 \mathrm{Gyr}$ when multiple lines of evidence, including elevated Mo, sulfide and organic carbon concentrations, and isotopic fractionations suggest that terrestrial and shallow marine environments became increasingly oxygenated (Eigenbrode and Freeman, 2006; Gregory et al., 2015; Kendall et al., 2010; Kurzweil et al., 2013; Kurzweil et al., 2015; Siebert et al., 2005; Wille et al., 2007; Zerkle et al., 2012). The deep ocean probably continued to be anoxic in the late Archean, but euxinia developed along some continental margins, at least temporarily (e.g. Reinhard et al., 2009; Scott et al., 2011). Oxidative weathering of the continents may have become more important (Stuieken et al., 2012), particularly during temporary and possibly local increases of free $\mathrm{O}_{2}$ in surface environments as indicated by geochemical evidence for pulses of enhanced oxidative weathering (Anbar et al., 2007; Kendall et al., 2015a; Stüeken et al., 2015a). Such oxidative weathering pulses can be reconciled with the persistence of sulfur MIF throughout this time, because oxygen production and weathering may have been restricted to microbial mats on land while the atmosphere stayed anoxic (Lalonde and Konhauser, 2015). This model is also consistent with the record of redox-sensitive minerals that rule out oxygen accumulation in river waters (England et al., 2002; Johnson et al., 2014; Rasmussen and Buick, 1999). Furthermore, the MIF signature can be reworked from older sediments, which may thus overprint intervals where MIF production was subdued (Reinhard et al., 2013a).

The disappearance of MIF in the early Paleoproterozoic rock record, around 2.4-2.3 Gyr, combined with photochemical models, suggests that atmospheric $p \mathrm{O}_{2}$ rose permanently above $10^{-5} \mathrm{PAL}$, quenching sulfur MIF production and causing the "Great Oxidation Event" (GOE) (Bekker et al., 2004; Luo et al., 2016; Pavlov and Kasting, 2002). It has been proposed that oxygen levels may even have approached modern levels during a brief " $\mathrm{O}_{2}$ overshoot" between 2.3 Gyr and 2.05 Gyr and then declined again afterwards (Bekker and Holland, 2012; Partin et al., 2013). According to models based on Cr isotopes, oxygen may have been as low as $10^{-3} \mathrm{PAL}$ during the Mesoproterozoic (Planavsky et al., 2014b). Sulfur isotopes and evaporites indicate that marine sulfate concentrations probably tracked $p \mathrm{O}_{2}$ with a peak during the Paleoproterozoic (Planavsky et al., 2012; Schröder et al., 2008), followed by a minimum between $\sim 1.7 \mathrm{Ga}$ and $\sim 1.0 \mathrm{Ga}$ (Kah et al., 2004; Luo et al., 2014b; Scott et al., 2014). The Mesoproterozoic ocean was likely ferruginous at depth, but euxinia apparently prevailed along continental margins (Arnold et al., 2004; Planavsky et al., 2011; Sperling et al., 2015). Atmospheric $p \mathrm{O}_{2}$ probably reached near-modern levels during the "Neoproterozoic Oxygenation Event" (NOE) between $0.8 \mathrm{Gyr}$ and 
0.65 Gyr (Kah and Bartley, 2011; Och and Shields-Zhou, 2012; Planavsky et al., 2014b), but the deep ocean may not have become permanently oxygenated until the rise of land plants in the Devonian (Dahl et al., 2010; Sperling et al., 2015; but see Chen et al., 2015, for an alternative view).

\subsection{Nitrogen as a redox proxy}

Nitrogen undergoes redox transformations at moderately high Eh levels, which makes it a useful proxy for oxygen abundances. Nitrate has a higher redox potential than ferric iron and sulfate, i.e. it is stable at higher Eh except under acidic conditions and extremely low $\mathrm{Fe}^{2+}$ concentration. (Fig. 1). Hence sulfate and $\mathrm{Fe}^{3+}$ are usually not strong enough oxidizers to produce nitrate or nitrite from organic-bound $\mathrm{NH}_{4}{ }^{+}$. Iron oxides can only oxidize $\mathrm{NH}_{4}{ }^{+}$to $\mathrm{NO}_{2}{ }^{-}$ or $\mathrm{NO}_{3}{ }^{-}$at $\mathrm{pH}$ 6-8 if $\mathrm{NH}_{4}{ }^{+}$concentrations are at least in the $100 \mu \mathrm{M}$ range at vanishingly low $\mathrm{NO}_{2}^{-}(<\mathrm{nM})$ while $\mathrm{Fe}^{2+}$ levels are less than a few $\mathrm{nM}(\mathbf{F i g} .2 \mathrm{a})$, which is unrealistic for the ironrich Precambrian ocean (Section 2.3). Photosynthetic oxidation of $\mathrm{NH}_{4}{ }^{+}$is unknown; the only photosynthetic pathway in the nitrogen cycle that has so far been detected oxidizes $\mathrm{NO}_{2}{ }^{-}$to $\mathrm{NO}_{3}{ }^{-}$ (Griffin et al., 2007). Hence free $\mathrm{O}_{2}$ appears to be a prerequisite for the production of significant amounts of nitrate under neutral to alkaline conditions. $\mathrm{MnO}_{2}$ may be the only alternative oxidizer that can take $\mathrm{NH}_{4}{ }^{+}$to $\mathrm{NO}_{3}{ }^{-}$(as well as to $\mathrm{NO}_{2}{ }^{-}$and $\mathrm{N}_{2}$ ) over a wide $\mathrm{pH}$ range (Hulth et al., 1999; Luther et al., 1997), but unlike ferric iron, which can be produced by anoxygenic photosynthesizers, $\mathrm{MnO}_{2}$ requires $\mathrm{O}_{2}$ itself, and it is not clear if $\mathrm{Mn}$-driven ammonium oxidation actually occurs in marine settings (Thamdrup and Dalsgaard, 2000). The inference of nitrification at any time in Earth's history therefore implies the presence of at least some appreciable amount of $\mathrm{O}_{2}$ in surface waters. A quantitative estimate is difficult, but it needs to be high enough that the amount of nitrate that is produced can become a major nitrogen source. Otherwise it would not be detectable in the $\delta^{15} \mathrm{~N}$ record (Section 3.1). For illustration, the maximum nitrate concentration in the Black Sea, where nitrate is too scarce to leave an isotopic signature (Fulton et al., 2012), is roughly 3.5 $\mu \mathrm{M}$ (Fuchsman and Murray, 2008), whereas the open ocean has concentrations up to around $35 \mu \mathrm{M}$ with nitrate being the major nitrogen source (Sverdrup et al., 1942). The threshold may lie somewhere between these two bounds, but it is probably variable, depending on productivity and the relative abundances of prokaryotes and eukaryotes.

\subsection{Effects of ferruginous conditions on the nitrogen cycle}

A characteristic feature of most of the Precambrian ocean is the abundance of dissolved ferrous iron $\left(\mathrm{Fe}^{2+}\right)$ in the deep sea (Poulton and Canfield, 2011). Canfield (2005) estimated concentrations of $40-120 \mu \mathrm{M}$ in the Archean compared to $<1 \mathrm{nM}$ today (Moore and Braucher, 2007), which raises the question about potential effects on the nitrogen cycle. Possible routes include (a) oxidation of $\mathrm{NH}_{4}{ }^{+}$by $\mathrm{Fe}^{3+}$, and (b) reduction of $\mathrm{NO}_{2}{ }^{-}$or $\mathrm{NO}_{3}{ }^{-}$by $\mathrm{Fe}^{2+}$. As noted above, iron-driven $\mathrm{NH}_{4}{ }^{+}$oxidation to $\mathrm{NO}_{2}{ }^{-}$or $\mathrm{NO}_{3}{ }^{-}$is thermodynamically infeasible under realistic marine conditions ( $\mathrm{pH} \sim 6-8$, Grotzinger and Kasting, 1993) with $\mu \mathrm{M}$ amounts of $\mathrm{Fe}^{2+}$. However, $\mathrm{NH}_{4}{ }^{+}$can be oxidized to $\mathrm{N}_{2}$ via the following reaction:

$$
6 \mathrm{Fe}(\mathrm{OH})_{3}+2 \mathrm{NH}_{4}^{+}+10 \mathrm{H}^{+} \rightarrow 6 \mathrm{Fe}^{2+}+\mathrm{N}_{2}+18 \mathrm{H}_{2} \mathrm{O}
$$

Between $\mathrm{pH} 6$ and $8, \Delta \mathrm{G}_{\mathrm{r}}$ is negative, i.e. the reaction is favored, if $\left[\mathrm{Fe}^{2+}\right]$ is $100 \mu \mathrm{M}$ or less and $\left[\mathrm{NH}_{4}{ }^{+}\right]$is $1 \mu \mathrm{M}$ or higher (Fig. 2b,c). For comparison, the Black Sea has up to $100 \mu \mathrm{M} \mathrm{NH}_{4}{ }^{+}$at 
depth (Brewer and Murray, 1973). Given the abundance of iron-oxide-bearing banded iron formation in the Archean and Paleoproterozoic (Isley and Abbott, 1999), this mechanism could have constituted a significant sink of nitrogen from the ocean and provided a nitrogen flux back to the atmosphere prior to the widespread appearance of denitrification in the Paleoproterozoic (Section 4.4).

The reduction of $\mathrm{NO}_{2}{ }^{-}$or $\mathrm{NO}_{3}{ }^{-}$by $\mathrm{Fe}^{2+}$ could also have been important, following either one of the two following reactions:

$$
\begin{aligned}
& 6 \mathrm{Fe}^{2+}+\mathrm{NO}_{2}^{-}+16 \mathrm{H}_{2} \mathrm{O} \rightarrow 6 \mathrm{Fe}(\mathrm{OH})_{3}+\mathrm{NH}_{4}^{+}+10 \mathrm{H}^{+} \\
& 6 \mathrm{Fe}^{2+}+2 \mathrm{NO}_{2}^{-}+14 \mathrm{H}_{2} \mathrm{O} \rightarrow 6 \mathrm{Fe}(\mathrm{OH})_{3}+\mathrm{N}_{2}+10 \mathrm{H}^{+}
\end{aligned}
$$

Between pH 6-8 and with $1-100 \mu \mathrm{M}\left[\mathrm{Fe}^{2+}\right]$ and 0.8 bar $\mathrm{N}_{2}$, both reactions are thermodynamically feasible $\left(\Delta \mathrm{G}_{\mathrm{r}}<-150 \mathrm{~kJ} / \mathrm{mol}\right)$, even with an unrealistic amount of $1 \mathrm{M}^{2}\left[\mathrm{NH}_{4}{ }^{+}\right]$and as little as 1 $\mathrm{nM}\left[\mathrm{NO}_{2}{ }^{-}\right]$. The overall conclusion does not change if $\mathrm{NO}_{3}{ }^{-}$is used instead of $\mathrm{NO}_{2}{ }^{-}$. Importantly, $\Delta \mathrm{G}_{\mathrm{r}}$ is always significantly more negative if $\mathrm{N}_{2}$ rather than $\mathrm{NH}_{4}{ }^{+}$is the end-product. Hence reaction 3 would usually be favored. Both reactions can be catalyzed by chemolithoautotrophic microbes over a wide range of temperatures, but the reduction to $\mathrm{NH}_{4}{ }^{+}$seems to be less common (Weber et al., 2006). Under ambient temperatures, microbial catalysis greatly accelerates nitrite and nitrate reduction (Weber et al., 2001), but it could occur abiotically under hydrothermal conditions (Brandes et al., 1998; Summers and Chang, 1993). As discussed in Section 5.1, this pathway could have lessened the supply of lightning-derived $\mathrm{NO}_{\mathrm{x}}$ to the earliest biosphere or prebiotic reaction networks, because a significant fraction of $\mathrm{NO}_{\mathrm{x}}$ would likely have been returned to the atmosphere as $\mathrm{N}_{2}$ gas instead of being converted into the more bioavailable form $\mathrm{NH}_{4}^{+}$.

Another implication of denitrification with ferrous iron is that nitrate and nitrite concentrations must have been negligible in the Precambrian deep ocean. Euxinic zones would have also excluded nitrate from the water column, because like $\mathrm{Fe}^{2+}, \mathrm{HS}^{-}$and other reduced sulfur compounds are powerful nitrate reductants (Shao et al., 2010). The same is true for $\mathrm{Mn}^{2+}$ (Luther et al., 1997), $\mathrm{H}_{2}$ (Karanasios et al., 2010) and $\mathrm{CH}_{4}$ (Raghoebarsing et al., 2006).

\subsection{Euxinia and nitrogen}

The observations of sulfide-driven denitrification (Section 2.1, Shao et al., 2010), combined with the significantly higher metabolic energy gain from nitrate reduction compared to sulfate reduction (Froelich et al., 1979) has led to the hypothesis that euxinia and nitrate are mutually exclusive (Boyle et al., 2013). In other words, one should never see evidence of both in the same sample. Where euxinia is observed, $\mathrm{N}_{2}$-fixation should have been the dominant mode of nitrogen acquisition. At first glance, this hypothesis is not born out by existing data, because there are numerous high $\delta^{15} \mathrm{~N}$ values reflecting nitrate uptake (Section 3.1) in euxinic black shales from Archean and Proterozoic basins; nitrogen isotopes are not correlated with pyritization of reactive iron, which usually increases with intensification of euxinia (Fig. 3). This observation can perhaps be reconciled with thermodynamics if the water column in these basins was strongly stratified. Iron speciation, which is the most commonly used proxy for detecting euxinia (Poulton and Canfield, 2005; Raiswell et al., 1988), primarily reflects bottom water conditions close to the sediment-water interface; it is not directly sensitive to processes in the surface ocean. The dominant mode of nitrogen metabolism, on the other hand, is controlled by regions of highest productivity, which is usually the photic zone. Biomass produced in the photic zone will eventually sink and carry its nitrogen isotopic signature to the sediments. Hence the 
combination of the two proxies $-\delta^{15} \mathrm{~N}$ and iron speciation - may in fact be a powerful tool to reconstruct gradients from oxic surface waters to euxinic or ferruginous bottom waters. If both nitrate and euxinia are reflected in sediments, then it may imply that the chemocline did not extend up into the photic zone. Biomarker evidence may be used to test this hypothesis (e.g. Brocks et al., 2005).

\section{The nitrogen isotope proxy in deep time}

Stable nitrogen isotopes $\left(99.6337 \%{ }^{14} \mathrm{~N}\right.$ and $\left.0.3663 \%{ }^{15} \mathrm{~N}\right)$ are the most widely used tool for reconstructing nitrogen cycling in ancient environments, because they are fractionated by several permil during many biogeochemical reactions (Fig. 4) (Casciotti, 2009; Robinson, 2001). Atmospheric $\mathrm{N}_{2}$, the largest surface reservoir of nitrogen, is used as a reference standard and therefore has a $\delta^{15} \mathrm{~N}$ value of $0 \%$, where $\delta^{15} \mathrm{~N}=\left[\left({ }^{15} \mathrm{~N} /{ }^{14} \mathrm{~N}\right)_{\text {sample }} /\left({ }^{15} \mathrm{~N} /{ }^{14} \mathrm{~N}\right)_{\text {air }}-1\right] \cdot 1000$. In the following, fractionations will be defined as $\varepsilon \approx \delta^{15} \mathrm{~N}_{\text {product }}-\delta^{15} \mathrm{~N}_{\text {reactant }}$, i.e. positive values indicate that the product is isotopically heavier.

\subsection{A primer on nitrogen isotopes in geological samples}

Biological nitrogen fixation (diazotrophy; reduction of $\mathrm{N}_{2}$ to $\mathrm{NH}_{4}{ }^{+}$, Table 1) with the most common Mo-based nitrogenase enzyme imparts a small fractionation of -1\%o on average with a range from $-2 \%$ to $+1 \%$, except under $\mathrm{Fe}^{2+}$ rich conditions or in thermophilic cultures where it can be as large as -4\% (Nishizawa et al., 2014; Zerkle et al., 2008; Zhang et al., 2014). Alternative nitrogenases containing $\mathrm{V}$ or Fe instead of Mo are less efficient and impart fractionations of $-6 \%$ to $-8 \%$ (Zhang et al., 2014); there is so far no evidence of biological $\mathrm{N}_{2}$ fixation by alternative nitrogenases in the Precambrian $\delta^{15} \mathrm{~N}$ record (Section 4). Diagenetic remineralization of organic-bound ammonium to dissolved $\mathrm{NH}_{4}{ }^{+}$renders residual biomass isotopically heavier by 1.4-2.3\% under oxic conditions (Freudenthal et al., 2001; Lehman et al., 2002; Moebius, 2013), but under anoxic conditions the effect is probably much smaller and maybe even reversed if light nitrogen is added by anaerobic diazotrophs (Lehman et al., 2002; Robinson et al., 2012) (Section 3.2). In an anoxic environment where fixed nitrogen is scarce and Mo-based nitrogen fixation is the major mode of nitrogen acquisition, one would thus expect $\delta^{15} \mathrm{~N}$ values between $-2 \%$ and $+1 \%$ in carbonaceous sediments. The Black Sea is a modern example (Fulton et al., 2012); anoxic events in the Cretaceous oceans with values down to -7\%o may represent cases where alternative nitrogenases were dominant (Zhang et al., 2014).

The $\mathrm{NH}_{4}{ }^{+}$that is released during organic matter degradation can accumulate in anoxic waters such as the modern Black Sea (Fuchsman and Murray, 2008) and serve as a nitrogen source. Non-quantitative $\mathrm{NH}_{4}{ }^{+}$assimilation imparts a fractionation of up to $-27 \%$ when $\left[\mathrm{NH}_{4}{ }^{+}\right]$> $20 \mu \mathrm{M}$, but the fractionation decreases to $-4 \%$ at lower concentrations (Hoch et al., 1992; Pennock et al., 1996; Waser et al., 1998). Under $\mathrm{NH}_{4}{ }^{+}$replete conditions one may thus expect light biomass in underlying sediments (i.e. organisms that assimilated a small proportion of the available $\mathrm{NH}_{4}{ }^{+}$pool) and a complementary heavy reservoir in sediments elsewhere, representing uptake of the residual heavy dissolved $\mathrm{NH}_{4}{ }^{+}$. There is no known modern example of this scenario, because in the case of the Black Sea, the dissolved $\mathrm{NH}_{4}{ }^{+}$does not reach far into the photic zone where most productivity occurs (Fuchsman and Murray, 2008). However, this mechanism has 
been invoked for Cretaceous anoxic events (Higgins et al., 2012) and the late Paleoproterozoic (Papineau et al., 2009).

In the presence of $\mathrm{O}_{2}, \mathrm{NH}_{4}{ }^{+}$is rapidly re-oxidized ('nitrified') to $\mathrm{NO}_{2}{ }^{-}(\varepsilon=+14 \%$ to $+38 \%$, Casciotti et al., 2003) and subsequently to $\mathrm{NO}_{3}{ }^{-}(\varepsilon=-13 \%$, Casciotti, 2009). In sum, the resulting $\mathrm{NO}_{3}{ }^{-}$is thus isotopically lighter than the original biomass. Nitrification is rapid and has been observed at $\mathrm{nM} \mathrm{O}_{2}$ levels in marine oxygen minimum zones (Füssel et al., 2012; Thamdrup et al., 2012). One would thus expect it to go to completion in most cases without leaving an isotopic trace in the geologic record. However, incomplete nitrification has been reported from sediments in the Bering Sea where biomass becomes increasingly heavy from assimilation of the residual $\mathrm{NH}_{4}{ }^{+}$(Granger et al., 2011; Morales et al., 2014). The light $\mathrm{NO}_{2}{ }^{-}$was lost by subsequent denitrification. It is unlikely that this mechanism is important on a global scale, because it lacks an output channel of heavy nitrogen from seawater and would thus throw the marine nitrogen cycle out of balance, counter to what is observed (Sigman et al., 2009). But it could presumably occur in individual basins, as proposed for late Archean lakes (Thomazo et al., 2011). It may be recognizable by a large scatter in sedimentary $\delta^{15} \mathrm{~N}$ data as in the modern Bering Sea where organic $\mathrm{N}$ ranges from $+2 \%$ to $+18 \%$ (Morales et al., 2014). This scatter may result from fluctuations between complete and incomplete nitrification over short timescales.

When nitrification goes to completion, the resulting $\mathrm{NO}_{3}{ }^{-}$becomes a major source of nitrogen for aerobic organisms. Fractionations associated with $\mathrm{NO}_{3}{ }^{-}$assimilation are often not expressed because assimilation typically goes to completion (Altabet and Francois, 1994; Thunell et al., 2004), except in modern Arctic settings (Somes et al., 2010). Under oxic conditions, marine sediments therefore approach the isotopic composition of $\mathrm{NO}_{3}{ }^{-}$in the overlying water column (Altabet and Francois, 1994; Thunell et al., 2004). This value is on average $+5 \%$ in the modern ocean (range mostly between $+3 \%$ and $+14 \%$ ), which is largely a result of isotopic fractionations imparted by denitrification. According to the canonical view, roughly $25 \%$ of all $\mathrm{NO}_{3}$ is denitrified to $\mathrm{N}_{2}$ in oxygen minimum zones with an average fractionation of $-25 \%$ (range $-5 \%$ to $-30 \%$ ) and $\sim 75 \%$ is denitrified in sediments with net fractionations of $0 \%$ (Devol, 2015; Sigman et al., 2009). Water-column denitrification thus returns isotopically light $\mathrm{N}_{2}$ to the atmosphere $\left(\delta^{15} \mathrm{~N}_{\mathrm{N} 2} \sim-20 \%\right.$ ), pushing residual $\mathrm{NO}_{3}{ }^{-}$up to $+5 \%$ (Fig. 5). Sedimentary denitrification acting on this residual heavy $\mathrm{NO}_{3}{ }^{-}$pool then returns heavy $\mathrm{N}_{2}$ to the atmosphere $\left(\delta^{15} \mathrm{~N}_{\mathrm{N} 2} \sim+5 \%\right.$ ) because it does not impart any additional fractionation. More recent work suggests that sedimentary denitrification imparts a net fractionation of -3\%o (Kessler et al., 2014; Rooze and Meile, 2016), i.e. producing $\mathrm{N}_{2}$ gas with $\delta^{15} \mathrm{~N}_{\mathrm{N} 2}=+2 \%$, while water-column denitrification only has a net fractionation of $-12.5 \%$ o $\left(\delta^{15} \mathrm{~N}_{\mathrm{N} 2}=-7.5 \%\right.$ ) (Kritee et al., 2012; Rooze and Meile, 2016). In that case, the mass balance of the two processes would be $68 \%$ to $32 \%$. Some denitrification may also be taken up by anammox (Section 3.2.1). In both models, the two return pathways lead to an isotopically balanced system. Deposition of biomass constitutes another heavy sink $\left(\delta^{15} \mathrm{~N}_{\mathrm{org}} \sim+5 \%\right)$, but it is comparatively minor under oxic conditions and has probably been balanced by volcanism and/or weathering of sedimentary rocks over geologic timescales (Berner, 2006). Unaltered ancient marine sediments that contain organic matter and fall within the modern marine range of +3 to $+14 \%$ are usually interpreted as reflecting an aerobic nitrogen cycle as in today's ocean (see Algeo et al., 2014, and Stüeken et al., 2015, for compilations of references). The absolute value will depend on the ratio of water-column to sedimentary denitrification, the net fractionation associated with water-column denitrification, contributions of anammox and DNRA (Section 3.2.2), and possible admixtures of diazotrophic biomass with a composition around -1\%. 
Independent constraints on those parameters are usually lacking, and so elevated $\delta^{15} \mathrm{~N}$ values are strictly speaking a qualitative rather than a quantitative proxy for aerobic nitrogen cycling.

\subsection{The role of minor nitrogen pathways}

The following pathways are less well explored, but may have been important in some environments or certain time periods.

\subsubsection{Anaerobic ammonium oxidation (anammox)}

Anaerobic ammonium oxidation coupled to nitrite reduction (abbreviated anammox) was only recognized relatively recently (Mulder et al., 1995; Van de Graaf et al., 1995), but it appears to play a significant role in nitrogen cycling in modern oxygen minimum zones (Kalvelage et al., 2013; Lam et al., 2009) This metabolism converts nitrite and ammonium to $\mathrm{N}_{2}$ via a hydrazine $\left(\mathrm{N}_{2} \mathrm{H}_{4}\right)$ intermediate. At present, it is unclear whether the essential nitrogen transforming enzymes utilize iron or copper cofactors. Phylogenetic analysis has identified both iron and copper binding domains in the genome of annamox bacteria (Ali et al., 2015), and copper limitation of anammox activity has been observed in the field (Jacquot et al., 2013). The evolutionary history of anammox is also poorly known. Since it has only been documented from a single bacterial phylum (Planctomycetes), it may be a recent evolutionary invention (Strous et al., 1999; Strous et al., 2006) (but see Brochier and Philippe, 2002, for an alternative view). However, the ingredients for anammox - ammonium and nitrite - may have existed in appreciable abundances in parts of the ocean since the late Archean, especially at times when the ocean was stratified (Sections 2.1, 2.4, 4.3). Unfortunately, the nitrogen isotopic fractionations imparted by anammox bacteria are too similar to those of canonical denitrifiers to distinguishing between the two metabolisms in the geologic record (Brunner et al., 2013).

\subsubsection{Dissimilatory nitrate reduction to ammonium (DNRA)}

There are additional biotic nitrogen transformation pathways that may play important biogeochemical roles, but at the moment are poorly understood. One is the dissimilatory nitrate reduction to ammonium (DNRA). All denitrifiers are capable of reducing nitrate as the first step of canonical denitrification, but denitrification continues toward an end product of $\mathrm{N}_{2}$ gas while DNRA produces ammonium. This process has long been known to occur in sediments (Sørensen, 1978), and it has recently been observed in the water column of the Namibian oxygen minimum zone (Kartal et al., 2007). In the water column, DNRA may provide up to $100 \%$ of the ammonium utilized by anammox bacteria (Kartal et al., 2007; Lam et al., 2009), while in some coastal settings, DNRA is thought to be responsible for $\sim 30 \%$ of all nitrate reduction (Giblin et al., 2013). It is therefore an important biogeochemical process.

The isotopic fractionation associated with DNRA has not yet been studied systematically, but may be on the order of $-30 \%$ with the residual nitrate becoming heavier (McCready et al., 1983). If so, then DNRA may be difficult to distinguish from denitrification, unless evidence of both the light ammonium and the heavy nitrate are preserved separately in different samples from the same basin. So far, no dataset exists where this is the case. Establishing the importance of DNRA in the Precambrian is important, because unlike denitrification to $\mathrm{N}_{2}$, DNRA retains all 
nitrogen in the marine ecosystem, provided that the resulting $\mathrm{NH}_{4}{ }^{+}$is not subsequently consumed by anammox.

\subsection{3. $\mathrm{NH}_{3}$ volatilization}

Large positive fractionations can also occur under anoxic conditions if the $\mathrm{pH}$ of the water column is highly alkaline. At standard conditions, dissolved $\mathrm{NH}_{4}{ }^{+}$dissociates to $\mathrm{NH}_{3}$ with a pKa of 9.25 (i.e. at $\mathrm{pH} 9.25$, both species exist at equal abundances), and $\mathrm{NH}_{3}$ can be lost by volatilization with a fractionation of $-45 \%$ ( $\mathrm{Li}$ et al., 2012). The residual heavy $\mathrm{NH}_{4}{ }^{+}$can be preserved in biomass. This mechanism has been reported from modern and ancient alkaline lakes (Stüeken et al., 2015c; Talbot and Johannessen, 1992).

\subsection{Preservation of nitrogen isotopes in the rock record}

A major challenge in nitrogen isotope studies of ancient rocks is the potential for diagenetic and metamorphic alteration (reviewed by Ader et al., 2016; Robinson et al., 2012). Diagenetic effects differ markedly between anoxic and oxic depositional environments. Under oxic diagenetic conditions in both natural and laboratory settings, $\delta^{15} \mathrm{~N}$ values of bulk sediments can increase by up to $\sim 4 \%$, especially when sedimentation rates are low and the exposure to oxygen is relatively long (e.g. Altabet et al., 1999; Freudenthal et al., 2001; Lehman et al., 2002). This increase is likely due to isotopic fractionations during $\mathrm{NH}_{4}{ }^{+}$release and partial oxidation in pore waters (Moebius, 2013; Prokopenko et al., 2006). In contrast, diagenesis under anoxic conditions, or under oxic conditions with high sedimentation rates, only imparts small isotopic fractionations of $<1 \%$, making bulk sedimentary nitrogen slightly lighter (Altabet et al., 1999; Lehman et al., 2002; Thunell et al., 2004). Anoxic diagenesis therefore has minimal effect on the utility of the $\delta^{15} \mathrm{~N}$ proxy in deep time. Importantly, this is despite the fact more than half of the organic nitrogen can be converted to clay-bound $\mathrm{NH}_{4}{ }^{+}$within the sediments (Müller, 1977; Rosenfeld, 1979; Schroeder and McLain, 1998). The conclusion that the effects of anoxic alteration are small is further supported by the preservation of consistent $\delta^{15} \mathrm{~N}$ offsets between biomarkers and bulk sediments from redox-stratified basins (Higgins et al., 2010; Higgins et al., 2012; Sachs and Repeta, 1999). Overall, light $\delta^{15} \mathrm{~N}$ values (<+2\%o) consistent with anaerobic nitrogen cycling are likely close to primary compositions, whereas positive $\delta^{15} \mathrm{~N}$ values $(>+2 \%$ ), which are commonly interpreted as evidence of aerobic nitrogen cycling, may have been altered and elevated during oxic diagenesis. This caveat prohibits quantitative interpretations of positive $\delta^{15} \mathrm{~N}$ values from ancient oxic settings. Nevertheless, these trends still imply that positive $\delta^{15} \mathrm{~N}$ values can be interpreted as evidence of oxic conditions, favoring nitrification of $\mathrm{NH}_{4}{ }^{+}$to $\mathrm{NO}_{3}{ }^{-}$, either in pore waters or in the water column. Even though it is not possible to use absolute $\delta^{15} \mathrm{~N}$ values from sedimentary rocks to calculate, for example, the degree of nitrate uptake in the photic zone (e.g. Fig. 5b), it remains valid to use them as a qualitative indicator for the stability of $\mathrm{NO}_{3}{ }^{-}$in the environment during the time of sediment deposition.

Metamorphism can increase sedimentary nitrogen isotope ratios by preferential volatilization of isotopically light $\mathrm{NH}_{3}$ or $\mathrm{N}_{2}$ (Bauersachs et al., 2009; Bebout et al., 1999; Bebout and Fogel, 1992; Boyd and Phillippot, 1998; Haendel et al., 1986; Jia, 2006; Mingram and Bräuer, 2001; Palya et al., 2011). However, the overall effect is variable and not always expressed (Busigny et al., 2003; Plessen et al., 2010; Yui et al., 2009), which prohibits precise corrections. However, the effect appears to be insignificant below greenschist facies $(<1 \%$ ) and 
minor within the greenschist facies (1-2\%o) (reviewed by Ader et al., 2016; Thomazo and Papineau, 2013). Rocks from upper greenschist to amphibolite facies or above may be metamorphically altered by several permil and are therefore generally avoided in studies aiming

There is less consensus regarding which nitrogen phase best preserves primary isotopic ratios. As noted above, more than half of the organic nitrogen can migrate into clay minerals during diagenesis. The residual organic-bound nitrogen phase can be analyzed separately by kerogen extraction, i.e. removal of silicate-bound ammonium with hydrofluoric acid (e.g. Godfrey and Falkowski, 2009; Kump et al., 2011; Stüeken et al., 2015b; Stüeken et al., 2015c), and this kerogen-phase is sometimes considered to be a more accurate recorder of primary nitrogen isotope ratios (Godfrey and Falkowski, 2009; Kump et al., 2011). However, experimental work suggests that kerogen can equilibrate isotopically with ammonium from exogenous fluids (Schimmelmann and Lis, 2010). Such fluids may be derived from other proximal organic-rich sediments (Svensen et al., 2008). Indeed, Paleoproterozoic sediments with evidence of metasomatic alteration show large offsets of up to $13 \%$ between kerogen-bound and silicate-bound nitrogen (Godfrey et al., 2013). Bulk rock $\delta^{15} \mathrm{~N}$ is enriched by $+4 \%$ compared to unperturbed rocks from the same basin, while kerogen-bound $\delta^{15} \mathrm{~N}$ is depleted by $-7 \%$. Hence metasomatic alteration is overall more pronounced in the kerogen fraction, meaning that kerogen extracts may not necessarily be a high-fidelity proxy for primary compositions. Additional problems can arise from contamination during the extraction process. In some studies, bulk rock $\mathrm{C} / \mathrm{N}$ ratios of some samples are higher than the $\mathrm{C} / \mathrm{N}$ ratios of the corresponding kerogen extracts (Godfrey and Falkowski, 2009; Kump et al., 2011), which is physically impossible. In other studies, the reproducibility of $\delta^{15} \mathrm{~N}$ analyses in kerogen extracts is unusually poor with sometimes more than 10\% difference between replicates (Beaumont and Robert, 1999). These issues highlight that additional care must be taken when analyzing and interpreting kerogenbound nitrogen. Bulk rock $\delta^{15} \mathrm{~N}$ values may therefore be the more accurate proxy if metasomatic alteration can be ruled out. Through uptake into clay minerals (Schroeder and McLain, 1998), bulk rocks can retain some of that nitrogen that was lost from organic matter during diagenesis and metamorphism and may therefore provide a more complete record of the primary biomass. Potential contributions of detrital ammonium need to be taken into account. Detrital ammonium addition may be significant in organic-poor siliciclastic sediments and needs to be addressed on a case-by-case basis (e.g. Ader et al., 2014; Busigny et al., 2013; Stüeken et al., 2015c). It is worth noting that there does not appear to be a significant difference in bulk $\delta^{15} \mathrm{~N}$ between lithologies (Appendix 2), which to first order may further suggest that variable ammonium retention or addition as a function of sample mineralogy does not lead to vast isotopic alteration of bulk rocks. In the following, we will focus on bulk rock $\delta^{15} \mathrm{~N}$, noting that more work is needed to settle this debate.

\section{The geologic record of Earth's nitrogen cycle}

There is a growing body of literature about nitrogen isotopes in ancient sedimentary rocks (Fig. 6) that allow us to reconstruct a plausible evolutionary pathway for Earth's biogeochemical nitrogen cycle. This reconstruction gains additional importance since Johnson \& Goldblatt (2015) calculated that the continental crust and its sedimentary cover contain roughly half as much nitrogen as the atmosphere with 1-2 orders of magnitude higher concentrations than the mantle. This large nitrogen reservoir was most likely created by biologically-mediated draw- 
down of atmospheric $\mathrm{N}_{2}$. Interest in this question has surged with the development of paleobarometric proxies (Kavanagh and Goldblatt, 2015; Kite et al., 2014; Marty et al., 2013; Som et al., 2016; Som et al., 2012) and evidence for a decrease in $\mathrm{N}_{2}$ pressure from $>0.5$ bar at better understanding of biological nitroget utilization in the past is therefore necessary to more accurately reconstruct atmospheric evolution.

\subsection{Hadean and Paleoarchean ( 4.6 - 3.5 Gyr)}

There are so far no reported measurements of nitrogen isotope ratios older than $\sim 3.8 \mathrm{Gyr}$. In rocks between 3.8 Gyr and 3.5 Gyr, negative values down to $-4.4 \%$ (Fig. 6, 7) have been interpreted as representing hydrothermal $\mathrm{NH}_{4}{ }^{+}$assimilation by thermophilic microbes (Pinti et al., 2001; Pinti et al., 2009), metasomatic alteration (Li et al., 2014; van Zuilen et al., 2005), or biological $\mathrm{N}_{2}$ fixation with alternative $\mathrm{V}$ or Fe nitrogenases (Zhang et al., 2014). Positive values up to $+12.2 \%$ from rocks of similar age are most commonly interpreted as reflecting metamorphic overprinting, which is known to increase $\delta^{15} \mathrm{~N}$ (Papineau et al., 2005; Thomazo and Papineau, 2013). The entire range of values could in theory also result from biological processes (Table 1). However, many of these samples are metamorphosed to amphibolite facies and/or were collected from hydrothermal veins (Beaumont and Robert, 1999; Pinti et al., 2001; Pinti et al., 2009; Ueno et al., 2004). Secondary alteration can therefore not be ruled out at this stage, prohibiting any firm conclusions about the Paleoarchean nitrogen cycle. Ammonium concentrations up to several hundred ppm in metasedimentary biotite grains at $\sim 3.75$ Gyr suggest that biological nitrogen consumption had already evolved at this time (Stüeken, in press), but so far no particular metabolism can be inferred from these data. Even less is known about the Hadean where no data exist.

\subsection{Mesoarchean (3.5-2.8 Gyr)}

While $\delta^{15} \mathrm{~N}$ data from the Paleoarchean are difficult to interpret due to the wide scatter in individual geological units, the Mesoarchean rock record shows more much more tightly clustered datasets (Fig. 7). The global mean from four different marine sections from 3.3-2.8 Ga is $+1.1 \pm 1.9 \%$ o $(\mathrm{n}=46)$ (Stüeken et al., 2015b; Yamaguchi, 2002). Most of these data points fall well within the range of Mo-based biological $\mathrm{N}_{2}$ fixation $(-2 \%$ to $+1 \%$, Zhang et al., 2014), especially if possible metamorphic alteration of rocks at greenschist facies $(+2.2 \pm 1.9 \%, \mathrm{n}=26)$ is taken into account. If correct, this conclusion would imply that alternative nitrogenases, which use Fe (Anf) or V (Vnf) instead of Mo and which cause larger isotopic fractionations up to -8\%o (Zhang et al., 2014), were either insignificant or had not yet evolved. Preferential Mo utilization would contradict the canonical view that Mesoarchean seawater was rich in ferrous iron but low in molybdenum (Anbar, 2008; Poulton and Canfield, 2011) (Section 5.3). However, molecular phylogenies suggest that Anf and Vnf are in fact more recent inventions, because they are only found in very few organisms that also possess and preferentially produce Nif (Boyd and Peters, 2013; McGlynn et al., 2012). Furthermore, Mo isotope data from 3.0 Gyr iron formations suggest appreciable levels of mobile molybdate ions in seawater (Planavsky et al., 2014a). Sufficient molybdenum concentrations in seawater could have been sustained by either localized oxidative weathering (Crowe et al., 2013; Guy et al., 2012; Planavsky et al., 2014a) or by low- 
temperature hydrothermal fluids which may contribute $\sim 10 \%$ of the Mo flux into the modern ocean (McManus et al., 2002).

As is true for most of Earth's history, only a few well-preserved rocks are available from the Mesoarchean. It is therefore impossible to know if biological Mo-based $\mathrm{N}_{2}$ fixation occurred globally, or if other reactions were more important in settings that are not represented in current sample sets. However, the data do at least suggest that the nitrogenase enzyme evolved prior to 3.2 Gyr (Stüeken et al., 2015b). Furthermore, the inference of an anaerobic nitrogen cycle at this time is consistent with current views of Archean redox states (Section 2.1).

\subsection{Neoarchean $(2.8-2.5 \mathrm{Gyr})$}

The Neoarchean rock record contains the first $\delta^{15} \mathrm{~N}_{\text {bulk }}$ values that are elevated above the $\mathrm{N}_{2}$-fixation range and are likely primary biologic signals rather than metamorphic or diagenetic overprints (Fig. 6, 7). Around $2.7 \mathrm{Gyr}$, marine $\delta^{15} \mathrm{~N}_{\text {bulk }}$ values from continental shelf settings rise from a Mesoarchean mean of $+1.1 \% \pm \pm 1.9 \%$ (Stüeken et al., 2015b; Yamaguchi, 2002) to a Neoarchean mean of $+4.2 \% \pm \pm 2.0 \% 0(n=160$, Busigny et al., 2013; Garvin et al., 2009; Godfrey and Falkowski, 2009; Stüeken et al., 2015c; Yamaguchi, 2002). Enriched $\delta^{15} \mathrm{~N}_{\text {bulk }}$ values up to $+7.5 \%$ from the Hamersley Group at $2.5 \mathrm{Gyr}$ are notably transient, i.e. restricted to a proposed temporary increase in surface oxygen levels (Anbar et al., 2007; Garvin et al., 2009), suggesting that nitrogen cycling was dynamic in space and time (Fig. 8b). While values near $0 \%$ probably reflect anaerobic nitrogen cycling dominated by Mo-based $\mathrm{N}_{2}$-fixation, the moderately high values can be interpreted as evidence of an episodic or localized aerobic nitrogen cycle reminiscent of the modern ocean, featuring nitrification, denitrification, and perhaps anammox (Busigny et al., 2013; Garvin et al., 2009; Godfrey and Falkowski, 2009). Models suggest that dissolved oxygen concentrations in marine oxygen oases may have been on the order of 1-10 $\mu \mathrm{M}$ at this time (Olson et al., 2013). This would have been sufficient for aerobic nitrogen metabolisms, which have been observed at $<1 \mu \mathrm{M} \mathrm{O}_{2}$ levels in modern oxygen minimum zones and cultures (Füssel et al., 2012; Martens-Habbena et al., 2009; Thamdrup et al., 2012). The onset of oxidative weathering of the continents would have raised the flux of Mo and other nutrients to the ocean (Lalonde and Konhauser, 2015; Reinhard et al., 2009; Stüeken et al., 2012) and perhaps facilitated nitrogen fixation as well as denitrification because, like nitrogenase, nitrate reductase is a Mo-containing enzyme (Godfrey and Glass, 2011). On the other hand, the expansion of euxinia in the Neoarchean (Reinhard et al., 2009; Scott et al., 2011) could have drawn down marine Mo levels and limited its bioavailability. The balance of these effects is unknown, and may have fluctuated, perhaps on similar timescales to fluctuations in atmospheric redox states (Izon et al., 2015; Zerkle et al., 2012). As noted above, sample limitation prohibits inferences about global nitrogen cycling, and so it is possible that occurrences of aerobic activity were local phenomena. But regardless of the spatial extent, repeated occurrences of positive $\delta^{15} \mathrm{~N}$ values coinciding with other indications of temporary oxygenation provide compelling evidence that biological nitrification and denitrification had evolved by $2.7 \mathrm{Gyr}$.

The Neoarchean may have marked the first time in Earth's history when the biosphere promoted a significant flux of $\mathrm{N}_{2}$ back into the atmosphere through coupled nitrification and denitrification. Until the Neoarchean, only minor amounts of nitrogen may have been returned to the atmosphere by dissociation of dissolved $\mathrm{NH}_{4}{ }^{+}$to volatile $\mathrm{NH}_{3}$, but this flux would may have been small if $\mathrm{NH}_{4}{ }^{+}$concentrations were low (Section 5.4). It has been hypothesized that the onset of nitrification/denitrification could thus have created a deficit of fixed nitrogen in water 
column by converting dissolved and organic-bound $\mathrm{NH}_{4}{ }^{+}$to $\mathrm{N}_{2}$ (Fennel et al., 2005). This deficit may in turn have enhanced biological $\mathrm{N}_{2}$-fixation rates. However, given the possible patchiness Paleoproterozoic.

\subsection{Paleoproterozoic (2.5-1.6 Gyr)}

Compared to the relatively abundant nitrogen data from the preceding Neoarchean and the following Mesoproterozoic, data from the Paleoproterozoic are rather scarce. This is unfortunate, because this time interval potentially has the most interesting nitrogen isotope record of all as major changes in the Earth's redox state apparently occurred then. Firstly, the "Great Oxidation Event" when the atmosphere became permanently oxygenated at levels above $10^{-5}$ times present atmospheric levels occurred early in the era around 2.4-2.3 Gyr (Bekker et al., 2004). This presumably meant that the surface ocean also became permanently oxygenated, potentially allowing an aerobic nitrogen cycle to prevail globally (Fig. 8c). This may have been further exacerbated during the proposed "oxygen overshoot" at 2.3-2.05 Gyr (Bekker and Holland, 2012). Furthermore, the expansion of euxinia and the initiation of the "Boring Billion" years of purported biogeochemical stasis around $1.85 \mathrm{Gyr}$, when atmospheric oxygen levels evidently dropped to levels insufficient to maintain more than a few $\mathrm{mM}$ of sulfate in the ocean (Luo et al., 2014b), may have resulted in a range of biogeochemical feedbacks between metal supply and nitrogen availability and speciation. However, the available data are only sufficient for providing hints as to whether these predicted effects on nitrogen cycling actually occurred.

The only Paleoproterozoic nitrogen isotopic data prior to the $\sim 2.35$ Gyr Great Oxidation Event come from the 2.48-2.46 Gyr Brockman banded iron formation of Australia (Busigny et al., 2013). These range from +0.4 to $+13.4 \%$, though almost all are between +4 and $+10 \%$. These consistently heavy values were explained as representing either i) a fully anoxic nitrogen cycle with partial assimilation of ammonium, ii) largely anoxic with partial nitrification in oxygen oases or by photoferrotrophic $\mathrm{Fe}^{3+}$, followed by complete denitrification, or iii) an aerobic nitrogen cycle with fractionation controlled by partial denitrification, as today (Busigny et al., 2013). The first alternative requires a complementary reservoir of isotopically light nitrogen, which has so far not been found. Although this option cannot be fully ruled out with the limited number of data points, there are so far no signs in its favor. The second pathway occurs now in non-marine settings but could plausibly have operated in a stratified pre-oxygenation ocean. However, it produces a wide range of heavy fractionations unlike the consistently moderate values observed in the Brockman, and it creates an isotopic imbalance in the ocean if it occurs on a global scale (Section 3.1). Thus the third option of aerobic nitrogen cycling, already known to operate in the Neoarchean, seems most likely - noting that sample limitation from a wider range of environments precludes greater certainty. If correct, then persistent aerobic cycling commenced shortly before the Great Oxygenation Event.

After atmospheric oxygenation, the hypothesized "oxygen overshoot" during the Lomagundi-Jatuli carbon isotope excursions between 2.22-2.06 Gyr (Bekker and Holland, 2012) should have greatly increased the availability of nitrate and could have enhanced denitrification rates leading to heavier $\delta^{15} \mathrm{~N}$ in sediments. Data from the 2.2-2.1 Gyr Ashanti Belt of Ghana (Jia and Kerrich, 2004) support these conjectures, as all samples fall between the notably heavy values of +9 to $+13 \%$. Corroborating $\delta^{15} \mathrm{~N}_{\text {bulk }}$ data come from the 2.09-1.98 Gyr upper Zaonega Formation in the Fennoscandian Shield (Kump et al., 2011) which also reach +7 to $+10 \%$. These 
values are as heavy as or heavier than most parts of the modern ocean and are thus also supportive of oxidizing conditions with abundant nitrate in surface waters and vigorous denitrification below in a strong chemocline. This conclusion is further supported by elevated iodate abundances in carbonates of similar age (Hardisty et al., 2014). Iodate has a similar redox potential as nitrate, and so if iodate was
plausible that nitrate was stable as well.

Following the "oxygen overshoot", phosphoritic shales in the 2.0 Gyr Aravalli Group, India show a very wide range of $\delta^{15} \mathrm{~N}_{\text {bulk }}$ from -5 to $+27 \%$ whereas non-phosphatic shales have a narrower range from +5 to $+12 \%$ (Papineau et al., 2013; Papineau et al., 2009). These generally positive values have been interpreted as reflecting vigorous denitrification under conditions of high productivity nourished by abundant but variable phosphorus levels but with a chemocline above anoxic bottom waters at differing depths. However, the negative values under phosphoritic conditions may result from nitrogen becoming limiting under phosphorus excess, prompting nitrogen fixation to dominate the nitrogen cycle. The extremely heavy values in some phosphoritic samples have been attributed to anaerobic decomposition of organic matter already isotopically heavy and then subsequent assimilation of the liberated ammonium, imparting further enrichment in the heavy isotope in the incorporating biomass (Papineau et al., 2009). If correct, this would be the so far only known site in the Precambrian where dissolved $\mathrm{NH}_{4}{ }^{+}$levels were high enough to result in an isotopic fractionation during assimilation. It is unknown if this would have been a local or global feature at this time.

The onset of widespread euxinic (sulfidic) conditions in the late Paleoproterozoic was marked by further changes in nitrogen cycling. In the 1.88-1.85 Gyr Gunflint and Biwabik Iron Formations of North America, where bottom waters were ferruginous and deposition was exclusively on the outer shelf, variable $\delta^{15} \mathrm{~N}$ values range from +2 to $+9 \%$ (Godfrey et al., 2013). The overlying $1.85-1.83$ Gyr Rove and Virginia Formations, where nearer-shore bottom water was euxinic, have heavier $\delta^{15} \mathrm{~N}_{\text {org }}$ values ( +5 to $+9 \%$ ) by an average of $+1.5 \%$ than deeper ferruginous facies (Godfrey et al., 2013). These spatial patterns have been interpreted as representing denitrification of abundant nitrate onshore and a relatively higher contribution of $\mathrm{N}_{2}$ fixation offshore (Godfrey et al., 2013). Although such a trend has so far only been reported from one basin of late Paleoproterozoic age, it may foreshadow the stronger cross-basinal isotopic gradients evident in the Mesoproterozoic.

\subsection{Mesoproterozoic (1.6-0.8 Gyr)}

Throughout the Mesoproterozoic, a return to ocean stratification and widespread euxinia may have controlled the nitrogen cycle (Anbar and Knoll, 2002). Canfield (1998) first proposed that from $\sim 1.8$ Gyr onwards, mildly oxygenated surface waters overlay a euxinic deep ocean, and that widespread microbial sulfate reduction to sulfide curtailed the deposition of iron oxides on marine shelves. Over the past decade, numerous isotopic and trace metal geochemical data have refined this hypothesis. The newly emerging view is one of a ferruginous deep ocean, euxinic continental margins and oxic surface waters (Planavsky et al., 2011; Shen et al., 2003) with significant spatial and temporal heterogeneity (Gilleaudeau and Kah, 2015; Sperling et al., 2014). Carbon isotopes further suggest that near-shore waters were dominated by aerobic metabolisms, while anaerobic processes became more important with depth (Luo et al., 2014a), especially in restricted epicontinental basins (Gilleaudeau and Kah, 2013a). Existing records of nitrogen isotopes suggest that nitrogen speciation and bioavailability may have mirrored these patterns. 
The Mesoproterozoic Belt basin ( 1.5 Gyr) shows a facies-dependent trend in $\delta^{15} \mathrm{~N}_{\text {bulk }}$ from $\sim 0 \%$ on average in deep water facies to $+3.7 \%$ in peritidal facies (Stüeken, 2013). This distinct onshore-offshore trend was interpreted to reflect a gradient from aerobic conditions with bioavailable nitrate along oxic basin margins to anaerobic, $\mathrm{N}_{2}$-fixation dominated regimes in anoxic waters offshore where nitrate was limiting (Fig. 8d). Any nitrate that was produced offshore was likely re-reduced rapidly and quantitatively such that it did not leave a geochemical signature. Transects of the Roper and Bangemall basins of similar age show comparable gradients on the order of $\sim 1.5 \%$ in the same direction (Koehler et al., in review). An important difference between these basins is that while offshore samples from the Belt basin have $\delta^{15} \mathrm{~N}_{\text {bulk }}$ values that consistently fall within the range of nitrogen fixation, some offshore samples from the Roper and Bangemall basins are slightly enriched relative to fractionations solely caused by fixation, suggesting a small degree of available nitrate and partial denitrification. This difference may be linked to basin geometry and the degree of restriction (Koehler et al., in review). However, all three basins show a peak in $\delta^{15} \mathrm{~N}_{\text {bulk }}$ values (and hence evidence of nitrate availability) in near-shore depositional facies and a minimum in offshore facies. Furthermore, there is no evidence of $\mathrm{Fe}$ - or V-based biological $\mathrm{N}_{2}$ fixation in the form of light $\delta^{15} \mathrm{~N}$ values ($6 \%$ to $-8 \%$, Table 1), suggesting that Mo was bioavailable despite low concentrations in midProterozoic seawater (Section 5.3). Of course, three basins cannot capture all heterogeneity in the global ocean at this time, but based on existing data it appears that the Mesoproterozoic ocean may have been much more nitrate-depleted than its Paleo- and Neoproterozoic counterparts. Both atmospheric $\mathrm{O}_{2}$ and dissolved $\mathrm{SO}_{4}{ }^{2-}$ may have dropped after the Paleoproterozoic (Luo et al., 2014b; Planavsky et al., 2014b), and so a concurrent decline in $\mathrm{NO}_{3}{ }^{-}$levels makes intuitive sense.

\subsection{Neoproterozoic (1.0-0.5 Gyr)}

Investigations of nitrogen isotopes in the Neoproterozoic are relatively scarce, but existing records suggest that in the late Neoproterozoic ( 750-550 Myr) nitrogen cycling looked much like it does today (Ader et al., 2014) (Fig. 8e). The distributions of nitrogen isotopes in these sedimentary successions analyzed to date converge on a mode of $\sim+4 \%$, similar to the modern mode of $\sim+5 \%$ (Tesdal et al., 2013), and basinal gradients have so far not been documented (Ader et al., 2014). A negative $\delta^{15} \mathrm{~N}$ excursion during the Shuram carbon isotope excursion is exception (Kikumoto et al., 2014). The most parsimonious explanation for this similarity to the modern ocean is that - as today $-\mathrm{NO}_{3}{ }^{-}$persisted throughout large parts of the water column and was reduced to $\mathrm{N}_{2}$ via water column denitrification in local oxygen minimum zones, leaving a positive isotopic signature in residual $\mathrm{NO}_{3}{ }^{-}$and resulting biomass. This interpretation implies expansion of oxygenated water masses in the Neoproterozoic. Although various paleoredox proxies indeed point to an increase in atmospheric and oceanic oxygen between $\sim 800$ and $\sim 550 \mathrm{Ma}$ (Canfield et al., 2007; Fike et al., 2006; Johnston et al., 2012; Kendall et al., 2015b; Planavsky et al., 2014b; Sahoo et al., 2012), others suggest anoxic conditions in roughly coeval strata (Canfield et al., 2008; Johnston et al., 2013; Schröder and Grotzinger, 2007; Sperling et al., 2015). Hence like the Neoarchean and Mesoproterozoic, the Neoproterozoic may have been a time of dynamic spatial and temporal redox fluctuations where $\mathrm{NO}_{3}{ }^{-}$was not abundant globally at all times. Future studies may reveal more heterogeneity in 686 nitrogen isotopic data than is currently known. 
The temporal correlation between oxygenation, a succession of low-latitude glaciations

\subsection{Phanerozoic (since $\sim 0.5$ Gyr)} (Hoffman et al., 1998), and the rise of architecturally complex life (Marshall, 2006; Narbonne, 2005) invites many hypotheses proposing cause-and-effect relationships between these events (Butterfield, 2009; Lenton et al., 2014; Sperling et al., 2013), but so far no single compelling story exists. A high-resolution record of nitrogen isotope ratios across Neoproterozoic glaciations is lacking, and so possible linkages between these events and the evolution of the nitrogen cycle are unknown. But if oxic conditions generally expanded during the Neoproterozoic, and if the chemocline receded to deeper waters, then this may mean that the marine nitrogen cycle became balanced (i.e. the major fluxes - nitrogen fixation and denitrification - were of roughly the same magnitude). Nitrate or trace metal limitation of denitrification would have been lifted or weakened by the increase in atmospheric and oceanic oxygen.

A recent compilation of $\delta^{15} \mathrm{~N}$ data through the Phanerozoic revealed a surprisingly dynamic picture with values near $0 \%$ and evidence of basinal stratification (Cremonese et al., 2014; Wang et al., 2013) in the early Paleozoic, a rise to values $>+2 \%$ with a maximum of $+8 \%$ from the early Carboniferous to the end of the Permian, a return to low values around $0 \%$ during most of the Mesozoic, and finally positive values around $+4 \%$ from the late Cretaceous onwards (Algeo et al., 2014). These long-term Phanerozoic nitrogen isotope trends are usually ascribed to climatic rather than redox fluctuations (Algeo et al., 2014; Altabet, 2007). According to this model, lower isotopic values $(-2 \%$ to $+2 \%$ ) occurred in greenhouse climates when sea-level was higher, such that the dominant locus of denitrification was ocean sediments rather than the water column. The net fractionation of denitrification would thus have been negligible and seawater nitrate would have had a composition around $0 \%$ (Algeo et al. 2014) (Fig. 5b). This hypothesis is supported by the canonical view that the final step in the oxygenation of Earth's surface occurred in the Neoproterozoic (Section 2.1) and that therefore the Phanerozoic ocean was fully oxygenated with only brief interruptions during anoxic events that favored a temporary return to anaerobic nitrogen cycling (e.g. Junium and Arthur, 2007; Ohkouchi et al., 2006; Rau et al., 1987; Schoepfer et al., 2012; Sephton et al., 2002). However, it is possible that the redox state of the ocean was not stable in the early Phanerozoic, and this may have significantly affected nitrogen cycling. A recent statistical investigation of redox proxy data suggests that oxygenation may have been protracted across the Neoproterozoic-Phanerozoic boundary, and atmospheric/oceanic oxygen levels may have remained significantly lower than modern values until as late as the Devonian (Sperling et al., 2015). If this were the case, then heterogeneous ocean redox states could still have dictated nitrogen speciation and cycling during the Paleozoic. With this possibility remaining open, more detailed basinal analyses of Paleozoic nitrogen isotopes (e.g. LaPorte et al., 2009; Luo et al., 2015) are required to parse out the differential influence of sea-level- and redox-driven variations in Phanerozoic nitrogen cycling.

Over the last 70 million years nitrogen isotope values in marine sediments have been relatively stable $(+3.8 \pm 1.9 \%$, Algeo et al., 2014), apart from short-term perturbations after the last glacial maximum in the Pleistocene (Altabet, 2007). These may have been caused by a large input of nitrogen from land during the continental glaciation (McElroy, 1983) and the oceans may still be recovering from this process (Christensen et al., 1987).

\section{Revisiting major themes in Precambrian nitrogen cycling}




\subsection{Was there a significant source of abiotically fixed nitrogen?}

While biological $\mathrm{N}_{2}$ fixation is by far the major source of nitrogen to the biosphere today (e.g. Ward, 2012), it is conceivable that abiotic sources were significant earlier in Earth's history, especially prior to the origin of the nitrogenase enzyme.

As shown in Table 2, the highest proposed abiotic flux of fixed nitrogen is $\mathrm{N}_{2}$ reduction on $\mathrm{TiO}_{2}$. However, this flux may be grossly overestimated, because (a) it assumes widespread deserts with abundant $\mathrm{TiO}_{2}$ as today, and (b) most $\mathrm{NH}_{3}$ that was produced was probably rapidly photolyzed back to $\mathrm{N}_{2}$ (cf. Kuhn and Atreya, 1979). In the absence of this $\mathrm{TiO}_{2}$ catalysis mechanism, $\mathrm{N}_{2}$ oxidation to $\mathrm{NO}_{\mathrm{x}}$ species in post-impact plumes becomes the major source $\left(\sim 10^{12}\right.$ mol/yr) (Kasting, 1990), which, however, could have been insignificant over stretches of many millions of years when no impacts occurred and it would have declined rapidly after $\sim 3.8 \mathrm{Gyr}$ (Kasting, 1990). Hydrothermal reduction of $\mathrm{N}_{2}$ to $\mathrm{NH}_{4}{ }^{+}$could have generated $10^{9}-10^{12} \mathrm{~mol} / \mathrm{yr}$ of fixed nitrogen, according to some scaled laboratory estimates (Smirnov et al., 2008); however, those calculations assume an arbitrary reaction yield and an unlimited supply of the FeNi alloy that acts as a reductant or catalyst. Furthermore, modern hydrothermal fluids that do not assimilate nitrogen from organic-rich sediments are noticeably $\mathrm{NH}_{4}{ }^{+}$-poor $(<0.01 \mathrm{mM}$, Lilley et al., 1993; von Damm, 1990). Assuming a modern hydrothermal water flux of $0.5-6 \cdot 10^{13} \mathrm{~kg} / \mathrm{yr}$ (Elderfield and Schultz, 1996; Emerson and Hedges, 2008), these low concentrations indicate an $\mathrm{NH}_{4}{ }^{+}$flux of $\sim 10^{8}-10^{9} \mathrm{~mol} / \mathrm{yr}$ or less, despite the fact that the modern ocean is rich in nitrate. Nitrate can also be reduced to $\mathrm{NH}_{4}{ }^{+}$(Brandes et al., 1998) and should thus raise the total $\mathrm{NH}_{4}{ }^{+}$ flux. Hence even if hydrothermal activity was ten times more vigorous in the earlier Precambrian, estimates of more than $10^{9} \mathrm{~mol} / \mathrm{yr}$ seem implausible.

Thus the major continuous sources (i.e. excluding impacts) of fixed nitrogen would have been lightning and volcanic eruptions, and a realistic steady-state abiotic production flux would probably have been on the order of $10^{10}-10^{11} \mathrm{~mol} \mathrm{~N} / \mathrm{yr}$. Rates of up to $10^{12} \mathrm{~mol} \mathrm{~N} / \mathrm{yr}$ may have been achieved under high $p \mathrm{CH}_{4}(1000 \mathrm{ppmv})$ and $<1 \% p \mathrm{CO}_{2}$ favoring the production of $\mathrm{HCN}$ later in the Archean (Tian et al., 2011; Zahnle, 1986), but $p \mathrm{CH}_{4}$ would probably have been low in the Hadean under prebiotic conditions prior to the origin of methanogenic microbes, lowering this flux to $10^{9} \mathrm{~mol} \mathrm{~N} / \mathrm{yr}$. Lightning and volcanism both generate $\mathrm{NO}_{\mathrm{x}}$ species which could have been reduced abiotically into the more bioavailable $\mathrm{NH}_{4}{ }^{+}$in hydrothermal vents, catalyzed by sulfide minerals or native metals (Brandes et al., 1998; Singireddy et al., 2012; Smirnov et al., 2008; Summers and Chang, 1993), provided that the reduction did not stop at $\mathrm{N}_{2}$ (Section 2.3). Reduction of $\mathrm{NO}_{\mathrm{x}}$ to $\mathrm{N}_{2}$ may have greatly diminished the abiotic supply of fixed nitrogen to prebiotic reactions and the earliest biosphere.

Today the marine biosphere fixes around $10^{13} \mathrm{~mol} \mathrm{~N} / \mathrm{yr}$ (e.g. Ward, 2012). Whether or not abiotic nitrogen sources were sufficient in the Precambrian would have depended on relative rates of primary productivity. Prior to the evolution of oxygenic photosynthesis, productivity may have been more than 10 times smaller than today, but once oxygenic photosynthesis evolved, it may have only been 5-10 times lower than modern levels throughout the Precambrian (Canfield et al., 2010; Canfield et al., 2006). The presumed constancy of organic carbon burial since at least 3.5 Gyr (Krissansen-Totton et al., 2015) perhaps further supports a continuously 
high nitrogen demand similar to the modern, exceeding plausible abiotic fluxes. A significant abiotic nitrogen source is further inconsistent with the isotopic record. Although isotopic fractionations imparted by abiotic $\mathrm{N}_{2}$ fixation mechanisms are not well known, laboratory and field measurements suggest that they span over 5-25\%o and perhaps more (Kuga et al., 2014; Moore, 1977). In particular $\mathrm{HCN}$ - the potentially largest source under high $p \mathrm{CH}_{4}$ and low $p \mathrm{CO}_{2}$ - may have been fractionated by tens to hundreds of permil relative to $\mathrm{N}_{2}$ (Kuga et al., 2014; Liang et al., 2007). Where $\mathrm{NO}_{\mathrm{x}}$ was produced, additional fractionations would likely have occurred during biotic or abiotic $\mathrm{NO}_{\mathrm{x}}$ reduction to $\mathrm{N}_{2}$ or $\mathrm{NH}_{4}{ }^{+}$. The Archean isotope record from 3.5 Gyr onwards does not show evidence of such large fractionations and is therefore unsupportive of a significant abiotic source of fixed nitrogen. This inference may be a further indication of an ancient origin of biological $\mathrm{N}_{2}$ fixation.

\subsection{Was there an Archean 'nitrogen crisis'?}

It has previously been proposed that a diminishing supply of abiotically fixed nitrogen resulted in a 'nitrogen crisis' in the Neoarchean and triggered the invention of the nitrogenase enzyme (Navarro-Gonzalez et al., 2001). It has further been suggested (Boyd et al., 2011b) that the first nitrogenase enzymes responsible for nitrogen fixation in the early biosphere were "proto-nitrogenases" ancestral to the current forms and thus not as specific or efficient at reducing unreactive $\mathrm{N}_{2}$ to bioavailable $\mathrm{NH}_{3}$. Based on inferred phylogenetic relationships between nitrogenase and bacteriochlorophylls, the timing of the takeover from proto-nitrogenase by modern Mo-nitrogenase has been estimated as occurring around 1.5-2.2 Gyr (Boyd et al., 2011a).

However, without effective biological nitrogen fixation, the potential volume of biomass should have been restricted, thus restraining opportunities for evolutionary experimentation and diversification due to the fewer number of evolving lineages in a small biota. This may be at odds with evidence for high metabolic diversity by 3.5 Gyr (Buick, 2007b). Furthermore, based on the consistent pattern and tight distribution of nitrogen isotope fractionation around a $\delta^{15} \mathrm{~N}_{\text {bulk }}$ value of $0 \% \pm 1.5 \%$ from $3.2 \mathrm{Gyr}$ to $2.5 \mathrm{Gyr}$ (except during temporary oxygenation events) in rocks with high post-metamorphic organic carbon levels of $5 \%$ (Garvin et al., 2009; Stïeken et al., 2015b), it appears that a highly efficient and isotopically specific nitrogen-fixing metabolic pathway was already operative. This implies that an enzyme with the capabilities of and very similar to modern Mo-nitrogenase with an iron-molybdenum cofactor at its active site was involved as early as $3.2 \mathrm{Gyr}$. This proposition is not incompatible with the idea of an ancestral nitrogenase lacking FeMo-co preceding Mo-nitrogenase; it is just incompatible with the timing of the transition. We note that the time constraints used to calculate when this transition occurred (Boyd et al., 2011a) are extremely conservative, in particular the placement of oxygenic photosynthesis at $2.5 \mathrm{Gyr}$. As there is now abundant evidence for the evolution of oxygenic photosynthesis well before this late date, perhaps even as early as 3.8 Gyr (Buick, 2008; Rosing and Frei, 2004), a revised calculation should yield molecular clock ages more compatible with the isotopic data. Secondly, increasing evidence for an origin of the nitrogenase enzyme in thermophilic methanogenic Archaea - perhaps the most ancient phylum on Earth - (Boyd et al., 2011a; Mehta and Baross, 2006; Nishizawa et al., 2014; Raymond et al., 2004) may suggest that nitrogenase is ancient and predates the radiation of cyanobacteria. If so, then abiotic nitrogen sources alone may already have been bio-limiting long before the possible evidence of cyanobacterial activity at 3.8 Gyr (Kasting and Siefert, 2001). 


\subsection{Was molybdenum a limiting constituent in nitrogen metabolisms?}

Molybdenum is an important constituent of nitrogenase and nitrate reductase (Fig. 1, Godfrey and Glass, 2011). Even though Mo isotopes indicate that some dissolved Mo was present in seawater back to $3.0 \mathrm{Gyr}$, possibly sourced from mild oxidative weathering or hydrothermal inputs (McManus et al., 2002; Planavsky et al., 2014a), dissolved Mo concentrations in the Precambrian ocean may have been as low as 1-10 nM compared to $100 \mathrm{nM}$ today (Anbar, 2008; Reinhard et al., 2013b; Scott et al., 2008). This raises the question of whether one or both of these enzymes were Mo-limited during early evolution (Anbar and Knoll, 2002).

Regarding assimilatory nitrate reductase, culturing experiments suggest that the cyanobacterial version of this enzyme functions normally with as little as $0.5 \mathrm{nM}$ Mo (Glass et al., 2009). Hence this metabolism may not have been affected by Mo shortage. However, eukaryotic nitrate reductases appear to be more sensitive, as shown in one experiment where their activity could be stimulated by raising Mo concentrations from < 2nM to 50nM (Axler et al., 1980). It is thus conceivable that eukaryotes were outcompeted for nitrate in Mo-depleted oceans in the Precambrian (Anbar and Knoll, 2002). Hence, even though there is evidence of nitrate availability from the Neoarchean onwards (Section 4.3), this does not necessarily imply that eukaryotes would have been ecologically significant. The minimum Mo requirements of dissimilatory nitrate reductases have to our knowledge not been studied.

With regards to nitrogen fixation, the situation is much more ambiguous. Under experimental conditions with cultures of modern cyanobacteria, $\mathrm{N}_{2}$-fixation rates decline significantly if Mo drops below 5-10nM, depending on the organism used (Glass et al., 2010; Zerkle et al., 2006). Fixation rates are still measurable but $80 \%$ suppressed with 1-5nM Mo (Zerkle et al., 2006). These thresholds coincide with the 1-10nM range of Mo that has most recently been proposed for the mid-Proterozoic ocean (Reinhard et al., 2013b), making Molimitation conceivable. This interpretation has even stimulated the hypothesis that planktonic cyanobacteria, i.e. the major diazotrophs in the modern ocean, did not evolve until the Neoproterozoic rise of Mo to near modern levels (Sánchez-Baracaldo et al., 2014) (Fig. 6). If so, then the earlier marine biosphere would have been severely nitrogen-limited. On the other hand, we see nitrogen isotopic evidence for Mo-based nitrogen fixation in marine shales dating back to the Meoarchean (Stuieken et al., 2015b). From 3.2 Gyr onwards, $\delta^{15} \mathrm{~N}$ values around $0 \%$ are common in sampled anoxic environments throughout the rest of the Archean and much of the Proterozoic (Section 4.2, 4.3, 4.5). There is so far no isotopic evidence of Fe- or V-based nitrogenase $\left(\delta^{15} \mathrm{~N}<-6 \%\right.$, Table 1$)$ at any time in the Precambrian. So, it is possible that Mo scarcity affected the overall rate of $\mathrm{N}_{2}$ fixation, but it did evidently not inhibit the expression of the nitrogenase enzyme.

We see two possible solutions to this conundrum. First, the cultures of modern cyanobacteria used in experiments may not have be representative of their Precambrian counterparts. Ancient microbes, in particular anaerobes, may have been better adapted to low Mo concentrations than modern ones. Second, Mo could have been made more bioavailable in Precambrian seawater if it was organically complexed by molybdophores or molybdate-binding siderophores, which are known to be excreted by some diazotrophs (Bellenger et al., 2008; Duhme et al., 1996; Liermann et al., 2005). The evolutionary history of molybdophores is unknown, but they could have facilitated Mo weathering (Liermann et al., 2005) as well as 
uptake from the water column (Duhme et al., 1996). In addition, organisms may have expressed enzymatic adaptations to facilitate Mo uptake and storage in the their cells (Glass et al., 2013).

\subsection{Was the Precambrian ocean rich in $\mathrm{NH}_{4}{ }^{+}$?}

It is often assumed that anoxic Precambrian oceans would have been rich in $\mathrm{NH}_{4}{ }^{+}$ (Beaumont and Robert, 1999; Falkowski and Godfrey, 2008), perhaps similar to the modern Black Sea (100 $\mu$ M, Brewer and Murray, 1973), but this hypothesis has so far not been verified. In a completely anoxic world with negligible amounts of sulfate and oxygen, as presumably in the earlier Archean or in the ferruginous deep ocean of the Mesoproterozoic (Planavsky et al., 2011; Poulton and Canfield, 2011), the major mode of nitrogen acquisition would likely have been biological $\mathrm{N}_{2}$ fixation, with minor contributions of fixed nitrogen from lightning or volcanism (see above). $\mathrm{NH}_{4}{ }^{+}$would have been released from degrading biomass by passive ammonification and during heterotrophic methanogenesis or fermentation, but these fluxes may have been relatively low, especially if degradation occurred in sediments where $\mathrm{NH}_{4}{ }^{+}$could be trapped by clay minerals. Hence in ferruginous basins the dissolved marine $\mathrm{NH}_{4}{ }^{+}$reservoir may have been fairly small.

With the influx of sulfate, substantially from the Neoarchean onwards (Stiueken et al., 2012), some organic matter would have been respired by microbial sulfate reduction. As noted above, sulfate is not a strong enough oxidizer to convert $\mathrm{NH}_{4}{ }^{+}$into $\mathrm{NO}_{2}{ }^{-}$or $\mathrm{NO}_{3}{ }^{-}$, but it can generate $\mathrm{N}_{2}$ via the following reaction:

$$
8 \mathrm{NH}_{4}{ }^{+}+3 \mathrm{SO}_{4}{ }^{2-} \rightarrow 4 \mathrm{~N}_{2}+3 \mathrm{HS}^{-}+12 \mathrm{H}_{2} \mathrm{O}+5 \mathrm{H}^{+}
$$

This reaction is thermodynamically feasible if $\mathrm{NH}_{4}{ }^{+}$concentrations and $\mathrm{SO}_{4}{ }^{2-} / \mathrm{HS}^{-}$ratios are high, and it is favored with increasing $\mathrm{pH}$ (Fig. 9). It is conceivable that close to the chemocline these conditions were met, releasing $\mathrm{N}_{2}$ back into the atmosphere. However, as $\mathrm{SO}_{4}{ }^{2-}$ became depleted with depth, as in modern euxinic basins (reviewed by Algeo and Lyons, 2006), the reaction would probably have become unfavorable. While some organic carbon may still have been converted to $\mathrm{CO}_{2}$ under those conditions, the organic-bound ammonium would likely have accumulated in the water column, as in the Black Sea. In other words, an ecosystem dominated by sulfate reduction, for instance along continental margins in the late Archean and midProterozoic when euxinia was more widespread (Arnold et al., 2004; Kendall et al., 2009; Kendall et al., 2011; Partin et al., 2015; Poulton et al., 2004; Reinhard et al., 2009; Scott et al., 2011; Sperling et al., 2015), may have favored high $\mathrm{NH}_{4}{ }^{+}$concentrations in deep water. Large quantities of dissolved $\mathrm{NH}_{4}{ }^{+}$may thus have been a rather localized phenomenon, restricted to euxinic environments.

There are additional arguments in support of relatively low $\mathrm{NH}_{4}{ }^{+}$concentrations in most of the Precambrian deep ocean. First, upwelling of a large $\mathrm{NH}_{4}{ }^{+}$reservoir should have led to non-quantitative $\mathrm{NH}_{4}{ }^{+}$assimilation and associated large isotopic fractionations (Table 1). However, apart from one Paleoproterozoic $\delta^{15} \mathrm{~N}$ dataset that has been explained by that mechanism (Papineau et al., 2009), there is so far no evidence of partial $\mathrm{NH}_{4}{ }^{+}$assimilation and hence for a large deep marine $\mathrm{NH}_{4}{ }^{+}$reservoir. This observation may suggest that $\mathrm{NH}_{4}{ }^{+}$ concentrations were similar to or lower than modern marine $\mathrm{NO}_{3}{ }^{-}$levels $(\sim 30 \mu \mathrm{M})$, which are assimilated quantitatively in most environments except at high latitudes (Altabet and Francois, 1994; Somes et al., 2010). The Black Sea with its $100 \mu \mathrm{M}$ of $\mathrm{NH}_{4}{ }^{+}$is an imperfect analogue, because upwelling is weak and so this $\mathrm{NH}_{4}{ }^{+}$is not readily bioavailable to organisms at the surface (Özsoy and Ünlüata, 1997). Second, nitrogen fixation is an energetically costly 
metabolism, requiring 16 ATP molecules per $\mathrm{N}_{2}$ molecule (e.g. Hoffman et al., 2014). If $\mathrm{NH}_{4}{ }^{+}$

918 had built up to high concentrations and was transported to the photic zone, then biological $\mathrm{N}_{2}$

919 fixation would presumably have slowed down until the $\mathrm{NH}_{4}{ }^{+}$reservoir had returned to lower

920 levels, especially if low concentrations of Mo limited the rate of biological $\mathrm{N}_{2}$ fixation (Section exceeding modern $\mathrm{NO}_{3}^{-}$levels in most of the Precambrian deep ocean.

\subsection{Could nitrous oxide have been a significant greenhouse gas in the Proterozoic?}

Nitrous oxide $\left(\mathrm{N}_{2} \mathrm{O}\right)$ is a potent greenhouse gas that can have a significant warming effect, depending on partial pressures of carbon dioxide $\left(\mathrm{CO}_{2}\right)$ or methane $\left(\mathrm{CH}_{4}\right)$ (Byrne and Goldblatt, 2014). $\mathrm{N}_{2} \mathrm{O}$ primarily enters the atmosphere via "leakage" in the biological nitrification and denitrification pathways as a metabolic byproduct that escapes reduction to $\mathrm{N}_{2}$. On the modern Earth, this comprises a small portion of the overall denitrification flux, but there is reason to believe that the biological $\mathrm{N}_{2} \mathrm{O}$ flux has varied along with the evolution of the nitrogen cycle through the Precambrian. The final step in the denitrification pathway - reduction of $\mathrm{N}_{2} \mathrm{O}$ to $\mathrm{N}_{2}-$ is only known to be catalyzed by the $\mathrm{N} 2 \mathrm{OR}$ enzyme, which is a multi-copper protein containing $12 \mathrm{Cu}$ atoms per dimer (Glass and Orphan, 2012; Haltia et al., 2003). Similar to Mo and many other transition metals, $\mathrm{Cu}$ is rapidly scavenged from the water column in the presence of hydrogen sulfide. Modeling of mid-Proterozoic ocean euxinia predicts that $\mathrm{Cu}$ should be the most strongly sequestered trace metal (Saito et al., 2003), which would render $\mathrm{Cu}$ essentially unavailable for microbial nitrogen transformations. Prior to the radiation of nitrification and denitrification in the Neoarchean (Section 4.3), there would probably not have been any significant $\mathrm{N}_{2} \mathrm{O}$ flux from the ocean to the atmosphere. However, from the Paleoproterozoic onwards, when we see persistent evidence of aerobic nitrogen cycling (Section 4.4), there may have been significant production of $\mathrm{N}_{2} \mathrm{O}$ in suboxic waters, if $\mathrm{Cu}$-limitation inhibited efficient $\mathrm{N}_{2} \mathrm{O}$ reduction to $\mathrm{N}_{2}$.

This has led to the hypothesis that especially in the Mesoproterozoic, when both aerobic nitrogen cycling and euxinia have been documented (Section 4.5), $\mathrm{N}_{2} \mathrm{O}$ may have been a significant greenhouse gas (Buick, 2007a). This idea is supported by experimental evidence showing that cultures of denitrifying bacteria indeed accumulate $\mathrm{N}_{2} \mathrm{O}$ at $\mathrm{Cu}$ concentrations < $\sim$ nM (Granger and Ward, 2003). According to some models, the resulting Mesoproterozoic $\mathrm{N}_{2} \mathrm{O}$ flux to the atmosphere could have been as high as 20 times the modern flux (Buick, 2007a; Roberson et al., 2011).

However, given new atmospheric oxygen constraints, this flux may have been insufficient to achieve $\mathrm{N}_{2} \mathrm{O}$ mixing ratios greater than a few ppbv. The accumulation of $\mathrm{N}_{2} \mathrm{O}$ in the atmosphere depends on the rate of photolytic destruction in the stratosphere, which on the early Earth would have been much higher than in today's ozone-shielded atmosphere. Therefore the ability of $\mathrm{N}_{2} \mathrm{O}$ to act as a significant greenhouse gas depends critically on the level of atmospheric oxygen (in addition to $\mathrm{CO}_{2}$ and $\mathrm{CH}_{4}$, Byrne and Goldblatt, 2014). At $p \mathrm{O}_{2}$ levels higher than 0.1 PAL, nitrous oxide can become an important greenhouse gas if the flux rates were somewhat elevated above modern levels (Roberson et al., 2011). However, an upper limit of 0.001 PAL for mid-Proterozoic $p \mathrm{O}_{2}$ has been proposed by Planavsky et al. (2014b) which is much lower than the threshold at which $\mathrm{N}_{2} \mathrm{O}$ mixing ratios decline markedly below the modern value of $\sim 330 \mathrm{ppbv}$ regardless of the flux rate (Roberson et al., 2011). High $\mathrm{CO}_{2}$ and $\mathrm{CH}_{4}$ levels may further reduce the greenhouse effect of $\mathrm{N}_{2} \mathrm{O}$ (Byrne and Goldblatt, 2014). Thus, the 
accuracy of the mid-Proterozoic $p \mathrm{O}_{2}, p \mathrm{CO}_{2}$ and $p \mathrm{CH}_{4}$ estimates is critical to the assessment of the $\mathrm{N}_{2} \mathrm{O}$-greenhouse hypothesis and further work needs to be done to assess the plausibility of this scenario.

When atmospheric and oceanic oxygen levels began to approach modern values in the Neoproterozoic, euxinia receded (Sperling et al., 2015) and the $\mathrm{Cu}$ inhibition of denitrification would have disappeared as well. However, there may have been periods of time in the Paleoproterozoic and early Paleozoic when euxinia was prevalent while $p \mathrm{O}_{2}$ was significantly higher than in the Mesoproterozoic (Sperling et al., 2015). If this was the case, then those two intervals may be promising candidates for an $\mathrm{N}_{2} \mathrm{O}$-greenhouse.

\subsection{Did the evolution of the nitrogen cycle play a role in eukaryogenesis?}

The advent of aerobic nitrogen cycling in the late Neoarchean, even if transient and localized, could have permitted the evolution of eukaryotes, as these organisms cannot fix nitrogen and preferentially assimilate nitrate whereas prokaryotes can fix nitrogen or preferentially assimilate ammonium (Fawcett et al., 2011). However, there is no strong evidence that eukaryotes existed at this time (French et al., 2015). Also the apparent expansion of nitrate availability in the early Paleoproterozoic evidently did not trigger the rise of eukaryotes to ecological dominance, as microfossil evidence of their existence does not appear until the late Paleoproterozoic (Knoll et al., 2006) and hydrocarbon biomarker evidence is not certain until the late Neoproterozoic (Summons et al., 1988). Although nitrate was perhaps necessary, it was likely not sufficient for eukaryogenesis.

Once eukaryotes had evolved in the late Paleoproterozoic, nitrate segregation into shallow coastal regions during the late Paleoproterozoic and Mesoproterozoic would have geographically restricted the distribution of eukaryotes, which may have retarded their evolutionary diversification and hindered their ecological dominance outside these regions (Stüeken, 2013). Perhaps not until nitrate became widely available throughout the ocean upon deep ocean oxygenation in the late Neoproterozoic (or perhaps even later) did eukaryotes take over the dominant ecological role and develop the diverse evolutionary aspect that we see today.

\section{Conclusions}

The evolution of the biogeochemical nitrogen cycle has been driven by biological innovations and the progressive, non-linear oxygenation of Earth's atmosphere and ocean. In particular, nitrogen isotopes can inform us about which metabolisms were active in ancient environments. $\mathrm{N}_{2}$ fixation may have been a dominant nitrogen uptake pathway in the Mesoarchean, consistent with widespread anoxia; nitrate became locally and temporarily more abundant in the Neoarchean, consistent with brief and possibly restricted increases in surface $\mathrm{O}_{2}$; and the Mesoproterozoic ocean was stratified with nitrate restricted to shallow waters, similar to stratification in sulfur at that time. From the Neoproterozoic onwards, nitrate appears to have been more common, though not permanently present. The inferred evolution of the nitrogen cycle thus strengthens current views of the progressive oxygenation of Earth's atmosphere and oceans.

Additional work is needed to fill major gaps in the database and to provide more accurate answers to some of the key questions about the Precambrian nitrogen cycle. Based on current evidence outlined above we draw the following conclusions: 

(Mehta and Baross, 2006; Raymond et al., 2004; Stüeken et al., 2015b). Abiotic nitrogen sources from lightning, volcanism and photochemistry were likely insufficient to sustain a significant biosphere (Section 5.1, 5.2), especially after the evolution of oxygenic photosynthesis and a concurrent increase in bioproductivity (Canfield et al., 2010).

1015

1016

1017

1018

1019

1020

1021

1022

1023

1024

1025

1026

1027

1028

1029

1030

1031

1032

1033

1034

1035

1036

1037

1038

1039

1040

1041

2. Molybdenum appears to have been sufficiently available to express nitrogenase enzymes since at least 3.2 Gyr, and it was evidently preferred over Fe and V nitrogenases throughout the entire Precambrian (Garvin et al., 2009; Godfrey and Falkowski, 2009; Koehler et al., in review; Stüeken, 2013; Stüeken et al., 2015b; Yamaguchi, 2002). Low Mo concentrations in seawater may have been compensated by biological adaptations (Section 5.5, e.g. Glass et al., 2013).

3. Following the first evidence for an oceanic nitrate reservoir at $\sim 2.7 \mathrm{Ga}$, dissolved nitrate levels were probably low and spatially heterogeneous throughout most of the Precambrian (Fig. 6, Section 4.3, 4.4, 4.5). This may have restricted the radiation of eukaryotes through much of the Proterozoic. On the other hand, nitrate availability alone was likely not the main driver of eukaryote evolution (Section 5.6).

4. Biologically-mediated nitrogen burial goes back to at least $3.8 \mathrm{Gyr}$, potentially affecting the atmospheric $\mathrm{N}_{2}$ reservoir (Goldblatt et al., 2009; Johnson and Goldblatt, 2015; Papineau et al., 2005; Som et al., 2016; Stüeken, in press; Stüeken et al., in review). Furthermore, biological $\mathrm{N}_{2} \mathrm{O}$ production may have been pronounced in the Proterozoic and possible in the early Paleozoic (Section 5.5, Buick, 2007a; Roberson et al., 2011). Through both of these processes, the nitrogen cycle could plausibly have played a role in global climate evolution, but missing constraints on fluxes and feedbacks prohibit firm quantitative assessments at this stage.

\section{Acknowledgements}

Financial support during the compilation of this manuscript was provided by the NASA postdoctoral program (EES), the NSF Graduate Research Fellowship Program (MAK), the Agouron Institute (MCK, RB) and the NSF FESD program (grant number 1338810, subcontract to RB). We thank Colin Goldblatt and one anonymous reviewer for constructive comments that improved the manuscript. 
Tables

Table 1: Metabolic nitrogen pathways and associated isotopic fractionations. Ammonification can be abiotic and is just included for completeness. Metal catalysts and isotopic fractionations are taken from the literature (Brunner et al., 2013; Buick, 2007a; Casciotti, 2009; Godfrey and Glass, 2011; Hoch et al., 1992; McCready et al., 1983; Nishizawa et al., 2014; Pennock et al., 1996; Waser et al., 1998; Zerkle et al., 2008; Zhang et al., 2014).

1050
Fractionations are defined as $\varepsilon \approx \delta^{15} \mathrm{~N}_{\text {product }}-\delta^{15} \mathrm{~N}_{\text {reactant }}$. Int. = intermediate reaction steps.

\begin{tabular}{|c|c|c|c|c|}
\hline pathway & & reaction & metals & fractionation [\%o] \\
\hline $\mathrm{N}_{2}$ fixation & & $\mathrm{N}_{2}+6 \mathrm{e}^{-}+8 \mathrm{H}^{+} \rightarrow 2 \mathrm{NH}_{4}^{+}\left(\rightarrow\right.$ org- $\left.-\mathrm{NH}_{2}\right)$ & Fe, Mo, (V) & $\begin{array}{c}\mathrm{Fe}, \mathrm{V}:-8 \text { to }-6 . \\
\text { Mo: }-2 \text { to }+1(-4 \\
\text { with Mo in high Fe) }\end{array}$ \\
\hline ammonification & & org- $\mathrm{NH}_{2}+2 \mathrm{H}^{+} \rightarrow \mathrm{NH}_{4}^{+}$ & & +1 \\
\hline $\begin{array}{l}\text { ammonium } \\
\text { assimilation }\end{array}$ & & $\mathrm{NH}_{4}^{+} \rightarrow$ org- $-\mathrm{NH}_{2}+\mathrm{H}^{+}$ & $\mathrm{Fe}$ & -4 to -27 \\
\hline \multirow[t]{4}{*}{ nitrification } & net: & $\mathrm{NH}_{4}^{+}+3 \mathrm{H}_{2} \mathrm{O} \rightarrow \mathrm{NO}_{3}^{-}+8 \mathrm{e}^{-}+10 \mathrm{H}^{+}$ & $\mathrm{Fe}, \mathrm{Mo}, \mathrm{Cu}$ & -1 to -25 \\
\hline & int: & $\mathrm{NH}_{4}^{+}+\mathrm{H}_{2} \mathrm{O} \rightarrow \mathrm{NH}_{2} \mathrm{OH}+2 \mathrm{e}^{-}+5 \mathrm{H}^{+}$ & $\mathrm{Fe}, \mathrm{Cu}$ & \\
\hline & & $\mathrm{NH}_{2} \mathrm{OH}+\mathrm{H}_{2} \mathrm{O} \rightarrow \mathrm{NO}_{2}^{-}+4 \mathrm{e}^{-}+5 \mathrm{H}^{+}$ & $\mathrm{Fe}$ & \\
\hline & & $\mathrm{NO}_{2}^{-}+\mathrm{H}_{2} \mathrm{O} \rightarrow \mathrm{NO}_{3}^{-}+2 \mathrm{e}^{-}+2 \mathrm{H}^{+}$ & $\mathrm{Fe}, \mathrm{Mo}$ & \\
\hline $\begin{array}{c}\text { nitrate } \\
\text { assimilation }\end{array}$ & & $\mathrm{NO}_{3}^{-}+8 \mathrm{e}^{-}+10 \mathrm{H}^{+} \rightarrow \mathrm{NH}_{4}^{+}+3 \mathrm{H}_{2} \mathrm{O}\left(\rightarrow\right.$ org- $\left.\mathrm{NH}_{2}\right)$ & $\mathrm{Fe}, \mathrm{Mo}$ & -5 to -10 \\
\hline \multirow[t]{5}{*}{ denitrification } & net: & $2 \mathrm{NO}_{3}^{-}+10 \mathrm{e}^{-}+12 \mathrm{H}^{+} \rightarrow \mathrm{N}_{2}+6 \mathrm{H}_{2} \mathrm{O}$ & $\mathrm{Fe}, \mathrm{Mo}, \mathrm{Cu}$ & -5 to -30 \\
\hline & int: & $\mathrm{NO}_{3}^{-}+2 \mathrm{e}^{-}+2 \mathrm{H}^{+} \rightarrow \mathrm{NO}_{2}^{-}+\mathrm{H}_{2} \mathrm{O}$ & $\mathrm{Fe}, \mathrm{Mo}$ & \\
\hline & & $\mathrm{NO}_{2}^{-}+\mathrm{e}^{-}+2 \mathrm{H}^{+} \rightarrow \mathrm{NO}+\mathrm{H}_{2} \mathrm{O}$ & $\mathrm{Fe},(\mathrm{Cu})$ & \\
\hline & & $2 \mathrm{NO}+2 \mathrm{e}^{-}+2 \mathrm{H}^{+} \rightarrow \mathrm{N}_{2} \mathrm{O}+\mathrm{H}_{2} \mathrm{O}$ & $\mathrm{Fe},(\mathrm{Cu})$ & \\
\hline & & $\mathrm{N}_{2} \mathrm{O}+2 \mathrm{e}^{-}+2 \mathrm{H}^{+} \rightarrow \mathrm{N}_{2}+\mathrm{H}_{2} \mathrm{O}$ & $\mathrm{Cu}$ & \\
\hline DNRA & & $\mathrm{NO}_{3}+8 \mathrm{e}^{-}+10 \mathrm{H}^{+} \rightarrow \mathrm{NH}_{4}^{+}+3 \mathrm{H}_{2} \mathrm{O}$ & $\mathrm{Fe}, \mathrm{Mo}$ & -30 (?) \\
\hline \multirow[t]{4}{*}{ ANAMMOX } & net: & $\mathrm{NO}_{2}^{-}+\mathrm{NH}_{4}^{+} \rightarrow \mathrm{N}_{2}+2 \mathrm{H}_{2} \mathrm{O}$ & $\mathrm{Fe}, \mathrm{Cu}$ ? & $\begin{array}{c}-26 \text { on } \mathrm{NH} 4+,-16 \text { on } \\
\mathrm{NO} 2-\end{array}$ \\
\hline & int: & $\mathrm{NO}_{2}^{-}+2 \mathrm{H}^{+}+\mathrm{e}^{-} \rightarrow \mathrm{NO}+\mathrm{H}_{2} \mathrm{O}$ & $\mathrm{Fe}, \mathrm{Cu}$ ? & \\
\hline & & $\mathrm{NO}+\mathrm{NH}_{4}^{+}+2 \mathrm{H}^{+}+3 \mathrm{e}^{-} \rightarrow \mathrm{N}_{2} \mathrm{H}_{4}+\mathrm{H}_{2} \mathrm{O}$ & $\mathrm{Fe}$ & \\
\hline & & $\mathrm{N}_{2} \mathrm{H}_{4} \rightarrow \mathrm{N}_{2}+4 \mathrm{H}^{+}+4 \mathrm{e}^{-}$ & $\mathrm{Fe}$ & \\
\hline
\end{tabular}


1054

1055

1056

1057

1058

1059

1060

1061

1062

1063

1064

1065

1066

1067

Table 2: Estimates of abiotic $\mathbf{N}_{\mathbf{2}}$ fixation rates compiled from the literature. Values are given in mol $\mathrm{N}$ per year. $\mathrm{NO}_{\mathrm{x}}$ species can undergo further reduction to $\mathrm{NH}_{4}{ }^{+}$under hydrothermal conditions (e.g. Brandes et al. 1998) and are therefore also relevant as a source of organic ammounium. Cat $=$ solid mineral catalyst. References: 1 . Smirnov et al. (2008), 2. Chyba and Sagan (1992), 3. Kasting (1990), 4. Mather et al. (2004), 5. Nna-Mvondo et al. (2005), 6. Navarro-Gonzalez et al. (1998), 7. Navarro-Gonzalez et al. (2001), 8. Kasting and Walker (1981) 9. Tian et al. (2011) and Zahnle (1986), 10. Schoonen \& Xu (2001), 11. Brandes et al. (1998), 12. Henderson-Sellers \& Schwartz (1980). 13. Canfield et al. (2010). Notes: a. production rate increases with $\mathrm{CO}_{2}$ but low $\mathrm{CO}_{2}$ levels may be more realistic (e.g. Kasting and Siefert, 2001); b. the minimum rate applies at low atmospheric $\mathrm{CH}_{4}$ levels and before the onset of widespread biological methanogenesis; c. assumes regeneration of FeNi alloy catalysts at high rates equivalent to water flux through ocean crust, but tectonic regeneration is likely ratelimiting; d. produced $\mathrm{NH}_{3}$ may be rapidly destroyed by photolysis (e.g. Kuhn and Atreya, 1979). Furthermore, assumes extensive deserts, which may not be realistic on the early Earth.

\begin{tabular}{|c|c|c|c|c|c|c|}
\hline mechanism & reactants & product & $\min$. & avg & $\max$. & ref. \\
\hline impact delivery & & reduced $\mathrm{N}$ & $1 \cdot 10^{3}$ & & $1 \cdot 10^{5}$ & 1 \\
\hline interplanetary dust & & reduced $\mathrm{N}$ & & $7.1 \cdot 10^{8}$ & & 2 \\
\hline post-impact plume & $\mathrm{N}_{2}+\mathrm{CO}_{2}$ & $\mathrm{NO}_{\mathrm{x}}$ & & $1.6 \cdot 10^{12}$ & & 3 \\
\hline volcanic eruptions & $\mathrm{N}_{2}+\mathrm{CO}_{2}$ & $\mathrm{HNO}_{3}$ & $10^{9}$ & & $10^{11}$ & 4 \\
\hline coronal discharge & $\mathrm{N}_{2}+\mathrm{CO}_{2}$ & $\mathrm{NO}_{x}$ & & $7.1 \cdot 10^{7}$ & & 5 \\
\hline volcanic lightning & $\mathrm{N}_{2}+\mathrm{CO}_{2}$ & $\mathrm{NO}_{\mathrm{x}}$ & & $1.7 \cdot 10^{10}$ & & 6 \\
\hline thunder-storm lightning ${ }^{a}$ & $\mathrm{~N}_{2}+\mathrm{CO}_{2}$ & $\mathrm{NO}_{\mathrm{x}}$ & $1.9 \cdot 10^{8}$ & & $2.1 \cdot 10^{10}$ & 7 \\
\hline lightning & $\mathrm{N}_{2}+\mathrm{CO}_{2}$ & $\mathrm{NO}_{x}$ & & $2.9 \cdot 10^{10}$ & & 8 \\
\hline UV photolysis ${ }^{\mathrm{b}}$ & $\mathrm{N}+\mathrm{CH}_{3}$ & $\mathrm{HCN}$ & $2.7 \cdot 10^{9}$ & & $2.7 \cdot 10^{12}$ & 9 \\
\hline hydrothermal reduction & $\mathrm{N}_{2}+\mathrm{HS}-\left(\mathrm{FeS}_{x}\right.$ cat. $)$ & $\mathrm{NH}_{4}^{+}$ & & & $8.5 \cdot 10^{7}$ & 10 \\
\hline hydrothermal reduction & $\mathrm{N}_{2}+\mathrm{Fe}^{0}, \mathrm{Fe}_{3} \mathrm{O}_{4}$ (cat.) & $\mathrm{NH}_{4}^{+}$ & $1 \cdot 10^{9}$ & & $1 \cdot 10^{11}$ & 11 \\
\hline hydrothermal reduction $^{c}$ & $\mathrm{~N}_{2}+\mathrm{Fe}^{0} \mathrm{Ni}^{0}$ (cat.) & $\mathrm{NH}_{4}^{+}$ & $1 \cdot 10^{9}$ & & $1 \cdot 10^{12}$ & 1 \\
\hline photochemical reduction $^{d}$ & $\mathrm{~N}_{2}+\mathrm{H}_{2} \mathrm{O}\left(\mathrm{TiO}_{2}\right.$ cat. $)$ & $\mathrm{NH}_{3}$ & $4.9 \cdot 10^{11}$ & & $4.9 \cdot 10^{12}$ & 12 \\
\hline modern $\mathrm{N}_{2}$ fixation & $\mathrm{N}_{2}+$ nitrogenase & org. $\mathrm{NH}_{4}^{+}$ & & $10^{13}$ & & 13 \\
\hline
\end{tabular}


1070

1071

1072

1073

1074

1075

1076

1077

1078

1079

1080

1081

1082

\section{Figures}

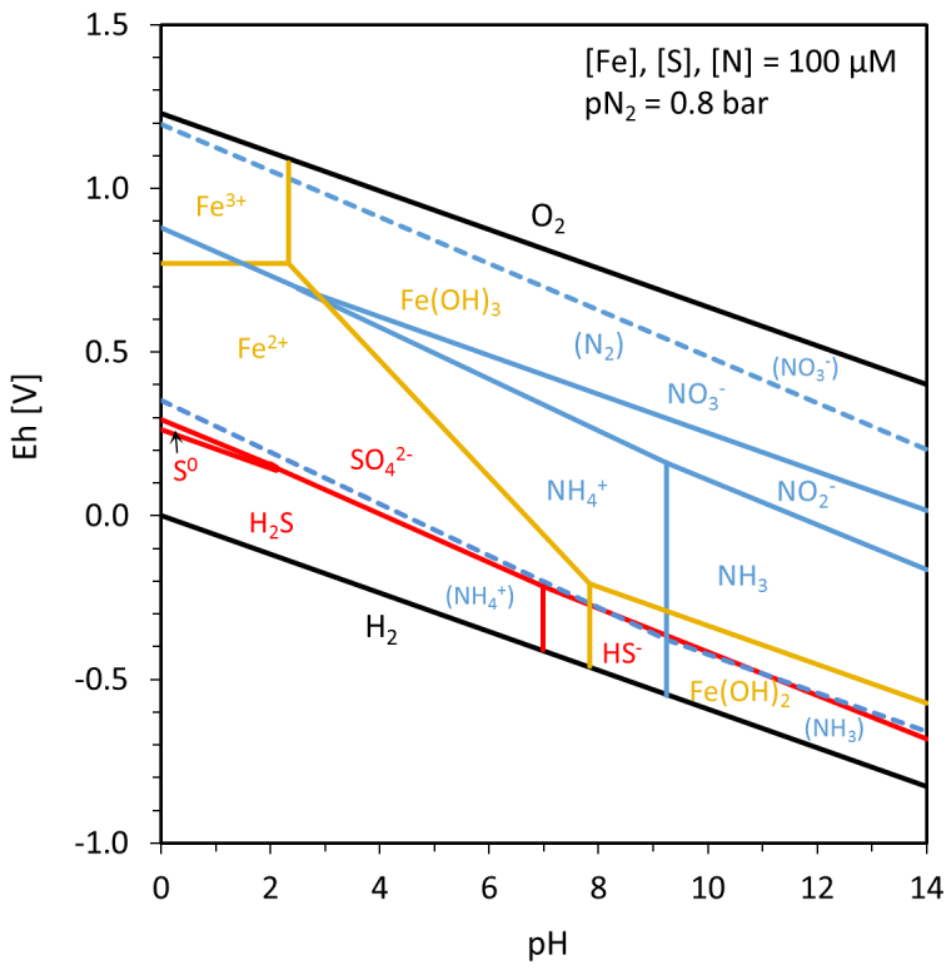

Figure 1: Eh-pH diagram for nitrogen, sulfur and iron. Fe concentrations for the Archean are taken from Canfield (2005), sulfur concentrations for the Archean are from Habicht et al. (2002), nitrogen levels based on concentrations in the Black Sea (Brewer and Murray, 1973; Fuchsman and Murray, 2008). For nitrogen, solid lines $=\mathrm{NH}_{4}{ }^{+} / \mathrm{NH}_{3}-\mathrm{NO}_{2}{ }^{-}-\mathrm{NO}_{3}{ }^{-}$system relevant for nitrification, dashed lines $=\mathrm{NH}_{4}{ }^{+} / \mathrm{NH}_{3}-\mathrm{N}_{2}-\mathrm{NO}_{3}{ }^{-}$system relevant for denitrification. Overall patterns change little with variations in concentrations and $\mathrm{pN}_{2}$. Diagrams were constructed with thermodynamic data from Stumm \& Morgan (1996) 
(a)

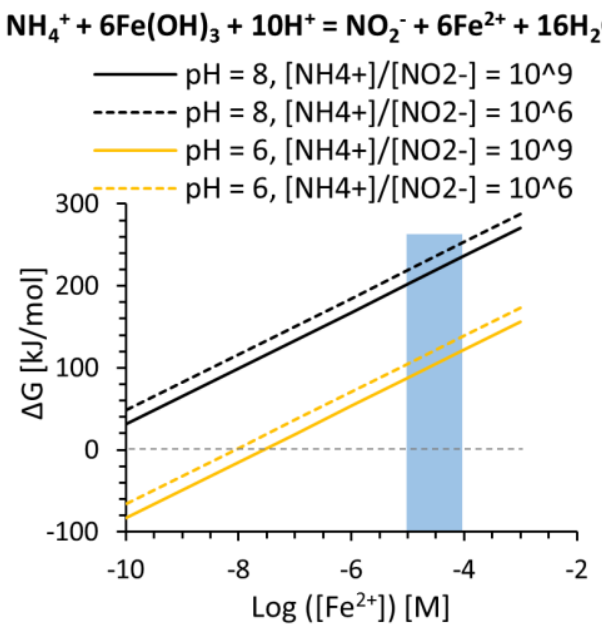

(b)

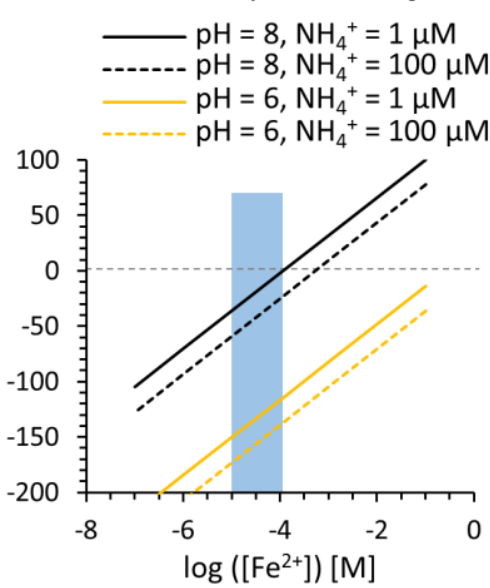

(c)

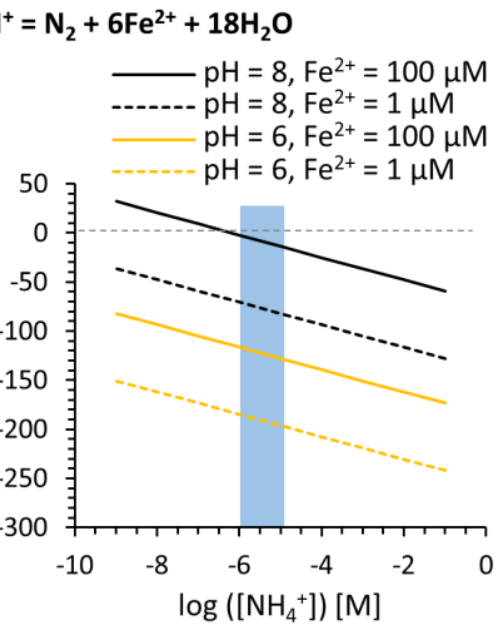

1084
1085

1086

1087

1088

1089

1090

1091

1092

1093

1094

1095

1096

Figure 2: Thermodynamic feasibility of iron-driven ammonium oxidation to $\mathrm{NO}_{2}{ }^{-}$and $\mathrm{N}_{2}$. Calculations were made with thermodynamic data from Stumm \& Morgan (1996). (a) $\Delta \mathrm{G}_{\mathrm{r}}$ for oxidation to $\mathrm{NO}_{2}{ }^{-}$as a function of $\mathrm{Fe}^{2+}$ ratios for $\mathrm{pH} 6$ (yellow) and $\mathrm{pH} 8$ (black) at $\left[\mathrm{NH}_{4}{ }^{+}\right] /\left[\mathrm{NO}_{2}{ }^{-}\right.$ ] ratios of $10^{9}$ (solid) and $10^{6}$ (dashed), blue bar $=$ range of $\mathrm{Fe}^{2+}$ levels proposed for the Archean (Canfield, 2005). (b) $\Delta \mathrm{G}_{\mathrm{r}}$ for oxidation to $\mathrm{N}_{2}$ as a function of dissolved $\mathrm{Fe}^{2+}$ for $\mathrm{pH} 6$ (yellow) and $\mathrm{pH} 8$ (black) with $\mathrm{NH}_{4}{ }^{+}$concentrations of $10^{-6} \mathrm{M}$ (solid) and $10^{-4} \mathrm{M}$ (dashed). (c) $\Delta \mathrm{G}_{\mathrm{r}}$ for oxidation to $\mathrm{N}_{2}$ as a function of dissolved $\mathrm{NH}_{4}{ }^{+}$for $\mathrm{pH} 6$ (yellow) and $\mathrm{pH} 8$ (black) with $\mathrm{Fe}^{2+}$ concentrations of $10^{-6} \mathrm{M}$ (dashed) and $10^{-4} \mathrm{M}$ (solid), blue bar $=$ range of total $\mathrm{N}$ (ammonium or nitrate) levels in the modern ocean. Reactions are thermodynamically feasibly if $\Delta \mathrm{G}_{\mathrm{r}}<0$ (grey dashed line). 


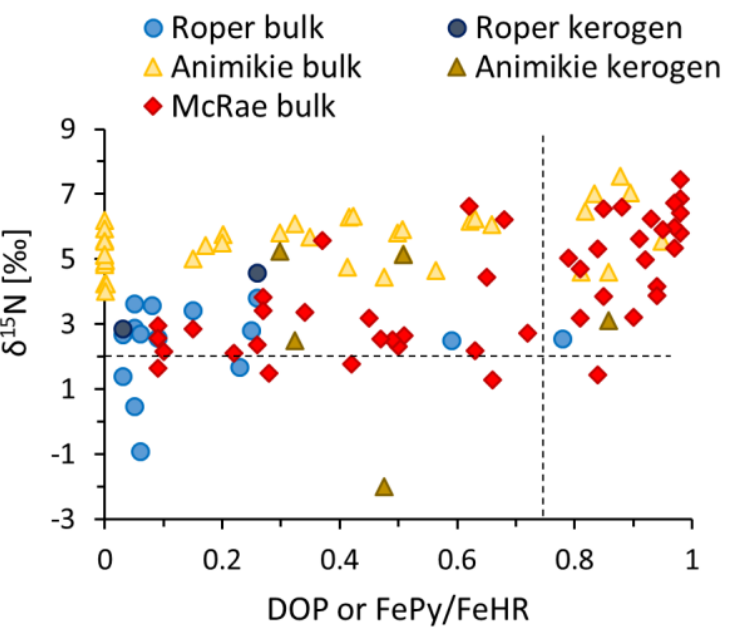

1098

1099

1100

1101

1102

1103

1104

1105

1106

1107

1108

1109

1110

1111

Figure 3: $\boldsymbol{\delta}^{\mathbf{1 5}} \mathbf{N}$ versus iron pyritization. DOP = degree of pyritization, defined as $\mathrm{Fe}_{\mathrm{Py}} /\left(\mathrm{Fe}_{\mathrm{Py}}+\mathrm{Fe}_{\mathrm{HCl}}\right)$, where $\mathrm{Fe}_{\mathrm{Py}}=$ pyrite-bound iron and $\mathrm{Fe}_{\mathrm{HCl}}=\mathrm{HCl}$-soluble iron; euxinia is inferred above $\sim 0.75$ (vertical dashed line) (Raiswell et al., 1988). $\mathrm{Fe}_{\mathrm{Py}} / \mathrm{Fe}_{\mathrm{HR}}$ stands for $\mathrm{Fe}_{\mathrm{Py}}$ over highly reactive iron, which comprises iron bound in carbonate, iron oxides and pyrite; euxinia is inferred above $0.7-0.8$, if the ratio of $\mathrm{Fe}_{\mathrm{HR}}$ over total iron exceeds 0.38 (Poulton and Canfield, 2005), which is fulfilled in these samples. Therefore, both methods provide comparable results. DOP applies to the Roper Gp (1.4 Gyr, Koehler et al., in review; Shen et al., 2003), $\mathrm{Fe}_{\mathrm{Py}} / \mathrm{Fe}_{\mathrm{HR}}$ applies to data from the Mt. McRae Fm (2.5 Gyr, Garvin et al., 2009; Reinhard et al., 2009) and from the Animikie Gp (1.86 Gyr, Godfrey and Falkowski, 2009; Poulton et al., 2004). Aerobic nitrogen cycling is commonly inferred where $\delta^{15} \mathrm{~N}$ is greater than $\sim+2 \%$ (horizontal dashed line). Data points in the top right quadrant violate the model of Boyle et al. (2013) 


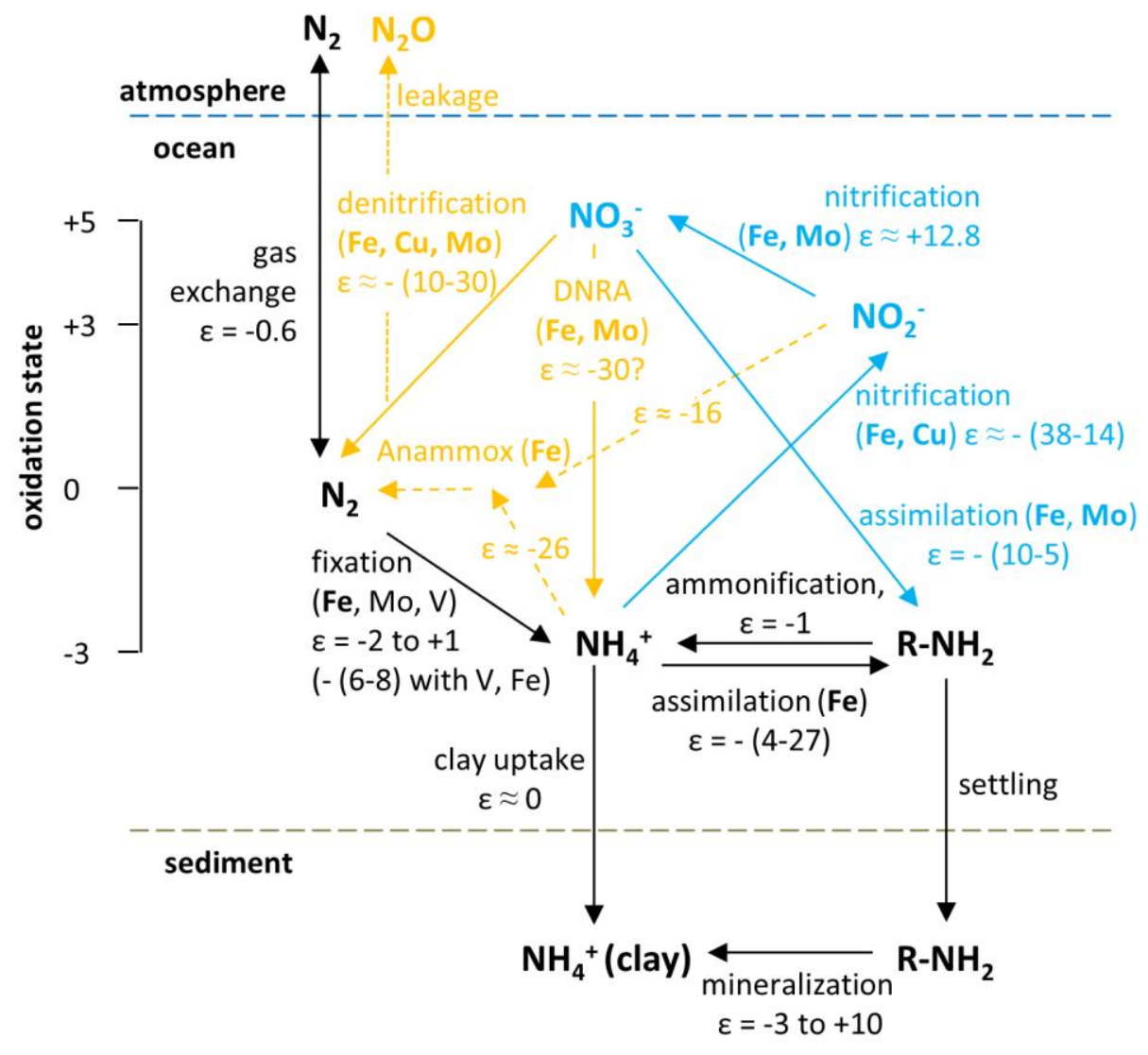

1112

1113

1114

1115

1116

1117

1118

1119

1120

Figure 4: Illustration of the marine nitrogen cycle. Essential metal cofactors are in bold. Black pathways show an anaerobic nitrogen cycle as envisioned for the earlier Archean, blue pathways mark oxic processes, and orange mark suboxic processes. Oxic and suboxic pathways did probably not radiate until the Neoarchean. See Table 1 and text for references. Adapted from Stuieken (2013) with additional information from McCready (1983), Zhang et al. (2014) and Brunner et al. (2013). 
1121
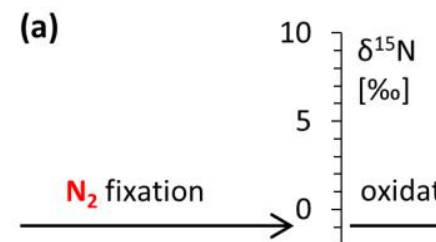

(b)

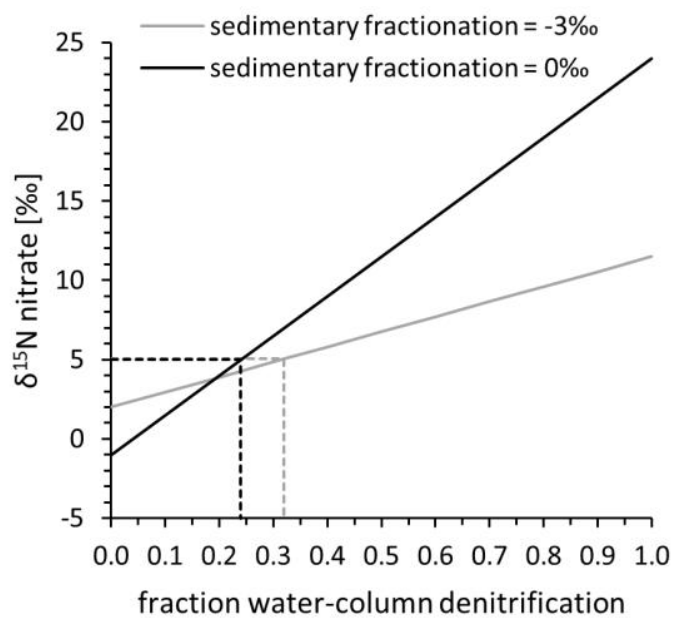

Figure 5: Nitrogen isotope mass balance in the modern ocean. (a) Mass balance, model, following the general formulation: $\delta^{15} \mathrm{~N}_{\mathrm{N} 2 \text { atmosphere }}+\varepsilon_{\mathrm{N} 2 \text { fixation }}=\delta^{15} \mathrm{~N}_{\mathrm{NO} 3-}+\varepsilon_{\text {denitrification, where }}$ $\varepsilon_{\text {denitrification }}=\mathrm{f}_{\text {sedimentary }} \cdot \varepsilon_{\text {sedimentary }}+\mathrm{f}_{\text {watercolumn }} \cdot \varepsilon_{\text {watercolumn. }}$. Nitrogen enters the system via $\mathrm{N}_{2}$ fixation with an average fractionation of $-1 \%$ o $\left(\varepsilon_{\mathrm{N} 2 f i x a t i o n}\right)$. In anoxic settings, this constitutes the major nitrogen source. In oxic settings, aerobic nitrogen cycling quantitatively converts $\mathrm{NH}_{4}{ }^{+}$ released from biomass into $\mathrm{NO}_{3}{ }^{-}$without net fractionation. The resulting $\mathrm{NO}_{3}{ }^{-}$with $\delta^{15} \mathrm{~N}_{\mathrm{NO}}$ - is reduced back to $\mathrm{N}_{2}$ in locally suboxic regions in the water column and in sediments. Black solid arrows $=$ traditional model, where water-column fractionation imparts a large fractionation of $25 \%$ o $\left(\varepsilon_{\text {watercolumn }}\right)$, but only makes up $\sim 25 \%$ of all denitrification $\left(f_{\text {watercolumn }}\right)$. Sedimentary denitrification $\left(f_{\text {sedimentary }}\right)$ imparts no significant net fractionation $\left(\varepsilon_{\text {sedimentary }}\right)$. Grey dashed arrows $=$ new emerging model, where sedimentary denitrification imparts a small fractionation of $-3 \%$ and water-column denitrification imparts a smaller net fractionation of $-12.5 \%$ on average. Adapted from Sigman et al. (2009). (b) The effect of the degree of water-column denitrification on the composition of residual $\mathrm{NO}_{3}{ }_{3}$. Black $=$ traditional model without fractionation in sediments; grey $=$ new model with fractionation of $-3 \%$ in sediments. Dashed lines $=$ mass balance in the modern ocean where $\delta^{15} \mathrm{~N}_{\mathrm{NO} 3} \approx+5 \%$. The composition of $\mathrm{NO}_{3}{ }^{-}$is transferred to biomass (and hence sediments) via quantitative $\mathrm{NO}_{3}{ }^{-}$assimilation in the photic zone. A higher degree of water-column denitrification can result in heavier $\delta^{15} \mathrm{~N}$ values. 

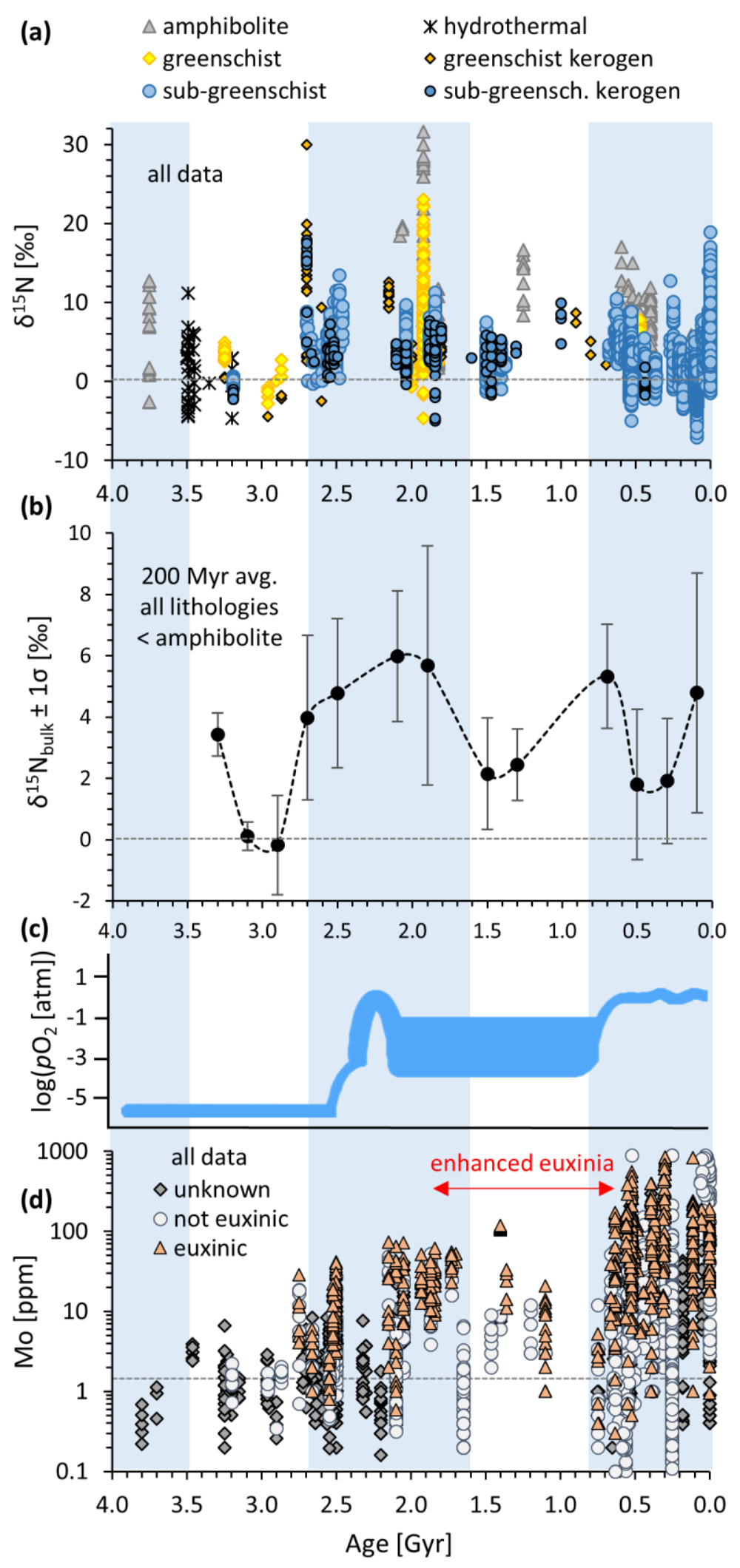
$1143200 \mathrm{Myr}$ average of all sub-greenschist and greenschist nitrogen isotope data, $\pm 1 \sigma$ for each bin. 1144 (c) Current view of atmospheric $p \mathrm{O}_{2}$ adapted from Lyons (2014). (d) Mo concentrations in 1145 marine shales compiled from the literature (Chen et al., 2015; Dahl et al., 2010; Gilleaudeau and 1146 Kah, 2013b; Little et al., 2015; Reinhard et al., 2013b, and references therein), sorted by redox 1147 state of the overlying water column as specified by the authors. Dashed horizontal line $=$ average 1148 upper continental crust for Mo (Rudnick and Gao, 2014), and atmospheric $\delta^{15} \mathrm{~N}$ for nitrogen 1149 isotopes. Vertical blue shading marks boundaries between time periods as discussed in the text. 

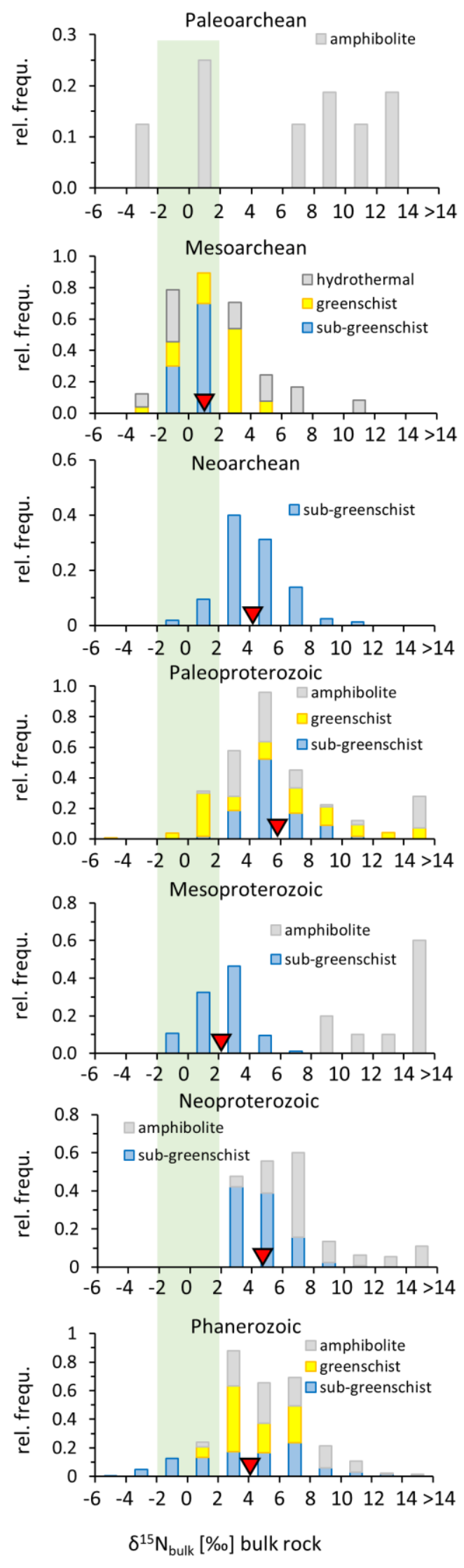
1151 Figure 7: Histograms of bulk nitrogen isotope data for different time periods. Data include 1152 all lithologies and are subdivided by metamorphic grade. Vertical green shaded bar $=$ most 1153 common range of Mo-based biological $\mathrm{N}_{2}$ fixation (Table 1). In the presence of high $\mathrm{Fe}$ 1154 concentrations, or with alternative nitrogenases, fractionations can be more negative. Red 1155 triangle $=$ average of sub-greenschist and greenschist samples in each interval.

1156 

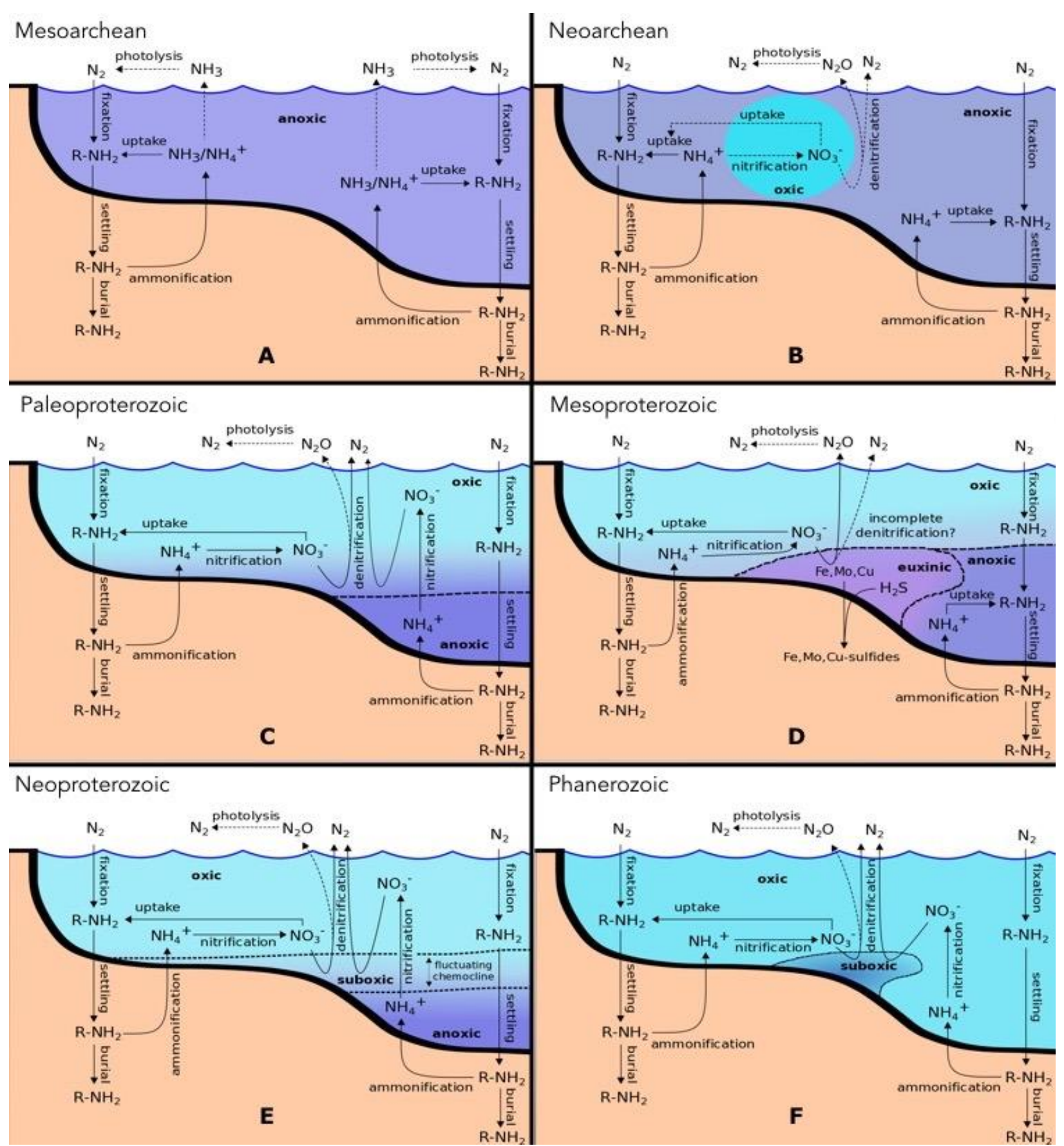

Figure 8: Sketch of the nitrogen cycle for different stages in Earth's history. Near-shore environments are depicted on the left, with a progression to outer shelf and deep ocean settings.

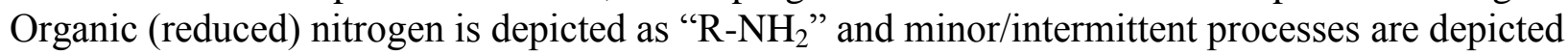
with dotted arrows. (a) Mesoarchean, 3.2-2.8Gyr. (b) Neoarchean, 2.8-2.5Gyr. (c) Paleoproterozoic, 2.5-1.8Gyr. (d) Mesoproterozoic, 1.8-0.8Gyr. (e) Neoproterozoic, 0.8-0.5Gyr. (f) Phanerozoic, 0.5 to modern. To avoid clutter, sedimentary denitrification has been omitted. Today, this process accounts for $\sim 70 \%$ of the total denitrification flux as calculated by isotopic mass balance (Sigman et al., 2009), and it is implied here wherever water-column denitrification 
1167 is depicted. The relative contributions of water-column and sedimentary denitrification may have 1168 varied in the past.

1169

1170 


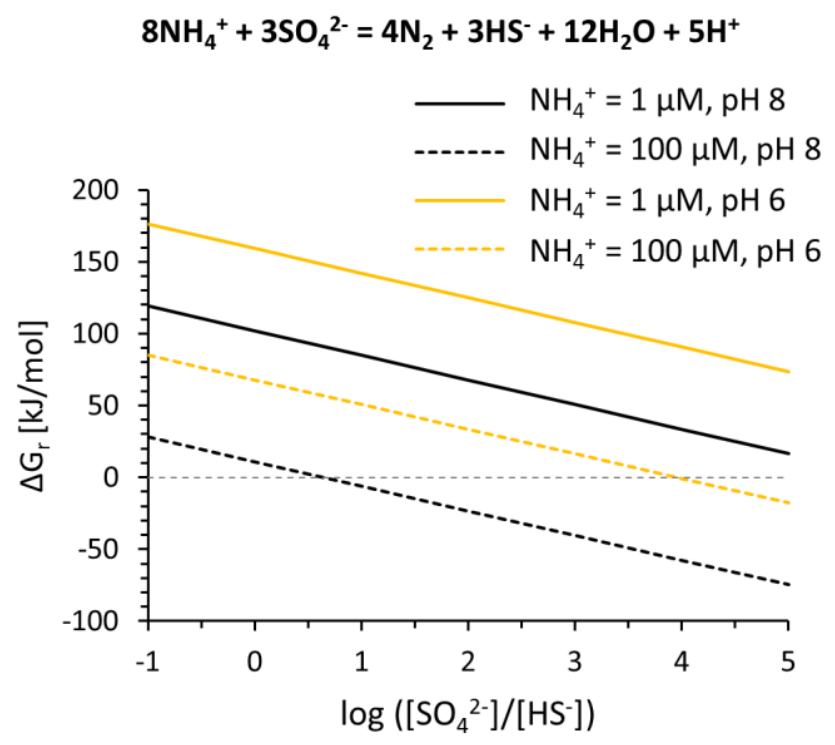

1172

1173

1174

1175

1176

1177

1178
Figure 9: Thermodynamic feasibility of sulfate-driven ammonium oxidation to $\mathbf{N}_{\mathbf{2}}$. Calculations were made with thermodynamic data from Stumm \& Morgan (1996). The free energy of the reaction $\left(\Delta \mathrm{G}_{\mathrm{r}}\right)$ is a function of $\mathrm{NH}_{4}^{+}$concentrations $\left(10^{-4} \mathrm{M}\right.$ in dashed, $10^{-6} \mathrm{M}$ solid $)$, $\mathrm{pH}$ ( 6 orange, 8 black), and the ratio of $\mathrm{SO}_{4}{ }^{2-}$ to $\mathrm{HS}^{-}$on the $\mathrm{x}$-axis. Reactions are thermodynamically feasible if $\Delta \mathrm{G}_{\mathrm{r}}<0$. 


\section{References}

Ader, M., Sansjofre, P., Halverson, G.P., Busigny, V., Trindade, R.I., Kunzmann, M. and Nogueira, A.C., 2014. Ocean redox structure across the Late Neoproterozoic oxygenation event: A nitrogen isotope perspective. Earth and Planetary Science Letters, 396: 1-13.

Ader, M., Thomazo, C., Sansjofre, P., Busigny, V., Papineau, D., Laffont, R., Cartigny, P. and Halverson, G.P., 2016. Interpretation of the nitrogen isotopic composition of Precambrian sedimentary rocks: Assumptions and perspectives. Chemical Geology, 429: 93-110.

Algeo, T.J. and Lyons, T.W., 2006. Mo-total organic carbon covariation in modern anoxic marine environments: Implications for analysis of paleoredox and paleohydrographic conditions. Paleoceanography, 21(1): DOI: 10.1029/2004PA001112.

Algeo, T.J., Meyers, P.A., Robinson, R.S., Rowe, H. and Jiang, G.Q., 2014. Icehousegreenhouse variations in marine denitrification. Biogeosciences, 11(4): 1273-1295.

Ali, M., Oshiki, M., Awata, T., Isobe, K., Kimura, Z., Yoshikawa, H., Hira, D., Kindaichi, T., Satoh, H., Fujii, T. and Okabe, S., 2015. Physiological characterization of anaerobic ammonium oxidizing bacterium 'Candidatus Jettenia caeni'. Environmental Microbiology, 17(6): 2172-2189.

Altabet, M.A., 2007. Constrains on oceanic $\mathrm{N}$ balance/imbalance from sedimentary ${ }^{15} \mathrm{~N}$ records. Biogeosciences, 15(4): 75-86.

Altabet, M.A. and Francois, R., 1994. Sedimentary nitrogen isotopic ratio as a recorder for surface ocean nitrate utilization. Global Biogeochemical Cycles, 8: 103-116.

Altabet, M.A., Pilskaln, C., Thunell, R., Pride, C., Sigman, D., Chavez, F. and Francois, R., 1999. The nitrogen isotope biogeochemistry of sinking particles from the margin of the Eastern North Pacific. Deep Sea Research Part I: Oceanographic Research Papers, 46(4): .655679.

Anbar, A., 2008. Elements and evolution. Science, 322: 1481-1483.

Anbar, A., Duan, Y., Lyons, T.W., Arnold, G.L., Kendall, B., Creaser, R.A., Kaufman, A.J., Gordon, G.W., Scott, C.T., Garvin, J. and Buick, R., 2007. A whiff of oxygen before the Great Oxidation Event? Science, 317(5846): 1903-1906.

Anbar, A.D. and Knoll, A.H., 2002. Proterozoic ocean chemistry and evolution: a bioinorganic bridge? Science, 297: 1137-1142.

Arnold, G.L., Anbar, A.D., Barling, J. and Lyons, T.W., 2004. Molybdenum isotope evidence for widespread anoxia in mid-Proterozoic oceans. Science, 304: 87-90.

Axler, R.P., Gersberg, R.M. and Goldman, C.R., 1980. Stimulation of nitrate uptake and photosynthesis by molybdenum in Castle Lake, California. Canadian Journal of Fisheries and Aquatic Sciences, 37(4): 707-712.

Bauersachs, T., Kremer, B., Schouten, S. and Sinninghe Damsté, J.S., 2009. A biomarker and $\delta^{15} \mathrm{~N}$ study of thermally altered Silurian cyanobacterial mats. Organic Geochemistry, 40(149-157): 2

Beaumont, V. and Robert, F., 1999. Nitrogen isotope ratios of kerogens in Precambrian cherts: a record of the evolution of atmosphere chemistry? Precambrian Research, 96: 63-82.

Bebout, G.E., Cooper, D.C., Bradley, A.D. and Sadofsky, S.J., 1999. Nitrogen-isotope record of fluid-rock interactions in the Skiddaw Aureole and granite, English Lake District. American Mineralogist, 84: 1495-1505. 
1224

1225

1226

1227

1228

1229

1230

1231

1232

1233

1234

1235

1236

1237

1238

1239

1240

1241

1242

1243

1244

1245

1246

1247

1248

1249

1250

1251

1252

1253

1254

1255

1256

1257

1258

1259

1260

1261

1262

1263

1264

1265

1266

1267

1268

1269

Bebout, G.E. and Fogel, M.L., 1992. Nitrogen-isotopic composition of metasedimentary rocks in the Catalina Schist, California: implications for metamorphic devolatilization history. Geochimica et Cosmochimica Acta, 56: 2839-2849.

Bekker, A. and Holland, H.D., 2012. Oxygen overshoot and recovery during the early Paleoproterozoic. Earth and Planetary Science Letters, 317: 295-304.

Bekker, A., Holland, H.D., Wang, P.-L., Rumble III, D., Stein, H.J., Hannah, J.L., Coetzee, L.L. and Beukes, N.J., 2004. Dating the rise of atmospheric oxygen. Nature, 427: 117-120.

Bellenger, J.P., Wichard, T., Kustka, A.B. and Kraepiel, A.M.L., 2008. Uptake of molybdenum and vanadium by a nitrogen-fixing soil bacterium using siderophores. Nature Geoscience, 1(4): 243-246.

Berner, R.A., 2006. Geological nitrogen cycle and atmospheric $\mathrm{N}_{2}$ over Phanerozoic time. Geology, 34(5): 413-415.

Boyd, E.S., Anbar, A.D., Miller, S., Hamilton, T.L., Lavin, M. and Peters, J.W., 2011a. A late methanogen origin for molybdenum-dependent nitrogenase. Geobiology, 9(3): 221-232.

Boyd, E.S., Hamilton, T.L. and Peters, J.W., 2011b. An alternative path for the evolution of biological nitrogen fixation. Frontiers in Microbiology, 2: doi:

10.3389/fmicb.2011.00205.

Boyd, E.S. and Peters, J.W., 2013. New insights into the evolutionary history of biological nitrogen fixation. Frontiers in Microbiology, 4: doi:10.3389/fmicb.2013.00201.

Boyd, S.R. and Phillippot, P., 1998. Precambrian ammonium biogeochemistry: a study of the Moine metasediments, Scotland. Chemical Geology, 144: 257-268.

Boyle, R.A., Clark, J.R., Poulton, S.W., Shields-Zhou, G., Canfield, D.E. and Lenton, T.M., 2013. Nitrogen cycle feedbacks as a control on euxinia in the mid-Proterozoic ocean. Nature Communications, 4: doi:10.1038/ncomms2511.

Brandes, J.A., Boctor, N.Z., Cody, G.D., Cooper, B.A., Hazen, R.M. and Yoder Jr, H.S., 1998. Abiotic nitrogen reduction on the early Earth. Nature, 395: 365-367.

Brewer, P.G. and Murray, J.W., 1973. Carbon, nitrogen and phosphorus in the Black Sea. Deep Sea Research and Oceanographic Abstracts 20(9): 803-818.

Brochier, C. and Philippe, H., 2002. A non-hyperthermophilic ancestor for Bacteria. Nature, 417: 244.

Brocks, J.J., Love, G.D., Summons, R.E., Knoll, A.H., Logan, G.A. and Bowden, S.A., 2005. Biomarker evidence for green and purple sulphur bacteria in a stratified Palaeoproterozoic sea. Nature, 437(7060): 866-870.

Brunner, B., Contreras, S., Lehmann, M.F., Matantseva, O., Rollog, M., Kalvelage, T., Klockgether, G., Lavik, G., Jetten, M.S.M., Kartal, B. and Kuypers, M.M., 2013. Nitrogen isotope effects induced by anammox bacteria. Proceedings of the National Academy of Sciences, 110(47): 18994-18999.

Buick, R., 2007a. Did the Proterozoic 'Canfield Ocean' cause a laughing gas greenhouse? Geobiology, 5(2): 97-100.

Buick, R., 2007b. The earliest records of life on Earth. In: W.T.I. Sullivan and J. Baross (Editors), Planets and Life: The emerging science of Astrobiology. Cambridge University Press, pp. 237-264.

Buick, R., 2008. When did oxygenic photosynthesis evolve? Philosophical Transactions of the Royal Society B, 363(1504): 2731-2743.

Busigny, V., Cartigny, P., Philippot, P., Ader, M. and Javoy, M., 2003. Massive recycling of nitrogen and other fluid-mobile elements $(\mathrm{K}, \mathrm{Rb}, \mathrm{Cs}, \mathrm{H})$ in a cold slab environment: 
evidence from HP to UHP oceanic metasediments of the Schistes Lustrés nappe (western Alps, Europe). Earth and Planetary Science Letters, 215( 1): 27-42.

Busigny, V., Lebeau, O., Ader, M., Krapež, B. and Bekker, A., 2013. Nitrogen cycle in the Late Archean ferruginous ocean. Chemical Geology, 362: 115-130.

Butterfield, N.J., 2009. Macroevolutionary turnover through the Ediacaran transition: ecological and biogeochemical implications. In: J. Craig, J. Thurow, B. Thusu, A. Whitham and Y. Abutarruma (Editors), Global Neoproterozoic Petroleum Systems: The Emerging Potential in North Africa. Special Publications. The Geological Society of London, London.

Byrne, B. and Goldblatt, C., 2014. Diminished greenhouse warming from Archean methane due to solar absorption lines. Climate of the Past Discussions, 10: 4229-4256.

Canfield, D.E., 1998. A new model for Proterozoic ocean chemistry. Nature, 396: 450-453.

Canfield, D.E., 2005. The early history of atmospheric oxygen: homage to Robert M. Garrels. Annual Review of Earth and Planetary Sciences, 33: 1-36.

Canfield, D.E., Glazer, A.N. and Falkowski, P.G., 2010. The evolution and future of Earth's nitrogen cycle. Science, 330(6001): 192-196.

Canfield, D.E., Poulton, S.W., Knoll, A.H., Narbonne, G.M., Ross, G., Goldberg, T. and Strauss, H., 2008. Ferruginous conditions dominated later Neoproterozoic deep-water chemistry. Science, 321(5891): 949-952.

Canfield, D.E., Poulton, S.W. and Narbonne, G.M., 2007. Late-Neoproterozoic deep-ocean oxygenation and the rise of animal life. Science, 315(5808): 92-95.

Canfield, D.E., Rosing, M.T. and Bjerrum, C., 2006. Early anaerobic metabolisms. Philosophical Transactions of the Royal Society B, 361: 1819-1836.

Casciotti, K.L., 2009. Inverse kinetic isotope fractionation during bacterial nitrite oxidation. Geochimica et Cosmochimica Acta, 73(7): 2061-2076.

Casciotti, K.L., Sigman, D.M. and Ward, B.B., 2003. Linking diversity and stable isotope fractionation in ammonia-oxidizing bacteria. Geomicrobiology Journal, 20(4): 335-353.

Chen, X., Ling, H.F., Vance, D., Shields-Zhou, G.A., Zhu, M., Poulton, S.W., Och, L., Jiang, S.Y., Cremonese, L. and Archer, C., 2015. Rise to modern levels of ocean oxygenation coincided with the Cambrian radiation of animals. Nature communications, 6.

Christensen, J.P., Murray, J.W., Devol, A.H. and Codispoti, L.A., 1987. Denitrification in continental shelf sediments has major impact on the oceanic nitrogen budget. Global Biogeochemical Cycles, 1(2): 97-116.

Chyba, C. and Sagan, C., 1992. Endogenous production, exogenous delivery and impact-shock synthesis of organic molecules: an inventory for the origins of life. Nature, 355: 125-132.

Cremonese, L., Shields-Zhou, G.A., Struck, U., Ling, H.F. and Och, L.M., 2014. Nitrogen and organic carbon isotope stratigraphy of the Yangtze Platform during the EdiacaranCambrian transition in South China. Palaeogeography, Palaeoclimatology, Palaeoecology, 398: 165-186.

Crowe, S.A., Døssing, L.N., Beukes, N.J., Bau, M., Kruger, S.J., Frei, R. and Canfield, D.E., 2013. Atmospheric oxygenation three billion years ago. Nature, 501(7468): 535-538.

Dahl, T.W., Hammarlund, E.U., Anbar, A.D., Bond, D.P., Gill, B.C., Gordon, G.W., Knoll, A.H., Nielsen, A.T., Schovsbo, N.H. and Canfield, D.E., 2010. Devonian rise in atmospheric oxygen correlated to the radiations of terrestrial plants and large predatory fish. Proceedings of the National Academy of Sciences, 107(42): 17911-17915. 
Devol, A.H., 2015. Denitrification, anammox, and $\mathrm{N}_{2}$ production in marine sediments. Annual Review of Marine Science, 7: 403-423.

Duhme, A.K., Dauter, Z., Hider, R.C. and Pohl, S., 1996. Complexation of molybdenum by siderophores: Synthesis and structure of the double-helical cis-dioxomolybdenum (VI) complex of a bis (catecholamide) siderophore analogue. Inorganic Chemistry, 35(10): 3059-3061.

Eigenbrode, J.L. and Freeman, K.H., 2006. Late Archean rise of aerobic microbial ecosystems. Proceedings of the National Academy of Sciences, 103(43): 15759-15764.

Elderfield, H. and Schultz, A., 1996. Mid-ocean ridge hydrothermal fluxes and the chemical composition of the ocean. Annual Review of Earth and Planetary Sciences, 24: 191-224.

Emerson, S. and Hedges, J., 2008. Chemical oceanography and the marine carbon cycle. Cambridge University Press, Cambridge, UK.

England, G.L., Rasmussen, B., Krapez, B. and Groves, D.I., 2002. Palaeoenvironmental significance of rounded pyrite in siliclastic sequences of the Late Archaean Witwatersrand Basin: oxygen-deficient atmosphere or hydrothermal alteration? Sedimentology, 49: 1133-1156.

Falkowski, P.G. and Godfrey, L.V., 2008. Electrons, life and the evolution of Earth's oxygen cycle. Philosophical Transactions of the Royal Society of London B, 363: 2705-2716.

Fawcett, S.E., Lomas, M.W., Casey, J.R., Ward, B.B. and Sigman, D.M., 2011. Assimilation of upwelled nitrate by small eukaryotes in the Sargasso Sea. Nature Geoscience, 4(10): 717 722.

Fennel, K., Follows, M. and Falkowski, P.G., 2005. The co-evolution of the nitrogen, carbon and oxygen cycles in the Proterozoic ocean. American Journal of Science, 305: 526-545.

Fike, D.A., Grotzinger, J.P., Pratt, L.M. and Summons, R.E., 2006. Oxidation of the Ediacaran ocean. Nature, 444(7120): 744-747.

French, K.L., Hallmann, C., Hope, J.M., Schoon, P.L., Zumberge, J.A., Hoshino, Y., Peters, C.A., George, S.C., Love, G.D., Brocks, J.J. and Buick, R., 2015. Reappraisal of hydrocarbon biomarkers in Archean rocks. Proceedings of the National Academy of Sciences, 112(9): 5915-5920.

Freudenthal, T., Wagner, T., Wenzhoefer, F., Zabel, M. and Wefer, G., 2001. Early diagenesis of organic matter from sediments of the eastern subtropical Atlantic: evidence from stable nitrogen and carbon isotopes. Geochimica et Cosmochimica Acta, 65(11): 1795-1808.

Froelich, P., Klinkhammer, G.P., Bender, M.A.A., Luedtke, N.A., Heath, G.R., Cullen, D., Dauphin, P., Hammond, D., Hartman, B. and Maynard, V., 1979. Early oxidation of organic matter in pelagic sediments of the eastern equatorial Atlantic: suboxic diagenesis. Geochimica et Cosmochimica Acta, 43(7): 1075-1090.

Fuchsman, C.A. and Murray, J.K., S.K., 2008. Concentration and natural stable isotope profiles of nitrogen species in the Black Sea. Marine Chemistry, 111: 90-105.

Fulton, J.M., Arthur, M.A. and Freeman, K.H., 2012. Black Sea nitrogen cycling and the preservation of phytoplankton $\delta^{15} \mathrm{~N}$ signals during the Holocene. Global Biogeochemical Cycles, 26(2).

Füssel, J., Lam, P., Lavik, G., Jensen, M.M., Holtappels, M., Günter, M. and Kuypers, M.M., 2012. Nitrite oxidation in the Namibian oxygen minimum zone. The ISME Journal, 6(6): 1200-1209.

Garvin, J., Buick, R., Anbar, A.D., Arnold, G.L. and Kaufman, A.J., 2009. Isotopic evidence for an aerobic nitrogen cycle in the latest Archean. Science, 323: 1045-1048. 
1361

1362

1363

1364

1365

1366

1367

1368

1369

1370

1371

1372

1373

1374

1375

1376

1377

1378

1379

1380

1381

1382

1383

1384

1385

1386

1387

1388

1389

1390

1391

1392

1393

1394

1395

1396

1397

1398

1399

1400

1401

1402

1403

1404

1405

Giblin, A.E., Tobias, C.R., Song, B., Weston, N., Banta, G.T. and Rivera-Monroy, V.H., 2013. The importance of dissimilatory nitrate reduction to ammonium (DNRA) in the nitrogen cycle of coastal ecosystems. Oceanography, 26(3): 124-131.

Gilleaudeau, G.J. and Kah, L.C., 2013a. Carbon isotope records in a Mesoproterozoic epicratonic sea: carbon cycling in a low-oxygen world. Precambrian Research, 228: 85-101.

Gilleaudeau, G.J. and Kah, L.C., 2013b. Oceanic molybdenum drawdown by epeiric sea expansion in the Mesoproterozoic. Chemical Geology, 356: 21-37.

Gilleaudeau, G.J. and Kah, L.C., 2015. Heterogeneous redox conditions and a shallow chemocline in the Mesoproterozoic ocean: evidence from carbon-sulfur-iron relationships. Precambrian Research, 257: 94-108.

Glass, J.B. and Orphan, V., 2012. Trace metal requirements for microbial enzymes involved in the production and consumption of methane and nitrous oxide. Frontiers in Microbiology, 3: $1-20$.

Glass, J.B., Poret-Peterson, A.T., Wolfe-Simon, F. and Anbar, A.D., 2013. Molybdenum Limitation Induces Expression of the Molybdate-Binding Protein Mop in a Freshwater Nitrogen-Fixing Cyanobacterium. Advances in Microbiology, 3 (6A): ID 37924.

Glass, J.B., Wolfe-Simon, F. and Anbar, A.D., 2009. Coevolution of metal availability and nitrogen assimilation in cyanobacteria and algae. Geobiology, 7: 100-123.

Glass, J.B., Wolfe-Simon, F., Elser, J.J. and Anbar, A.D., 2010. Molybdenum-nitrogen colimitation in freshwater and coastal heterocystous cyanobacteria. Limnology and Oceanography, 55(2): 667-676.

Godfrey, L.V. and Falkowski, P.G., 2009. The cycling and redox state of nitrogen in the Archaean ocean. Nature Geoscience, 2: 725-729.

Godfrey, L.V. and Glass, J.B., 2011. The geochemical record of the ancient nitrogen cycle, nitrogen isotopes, and metal cofactors. Methods in Enzymology, 486: 483-506.

Godfrey, L.V., Poulton, S.W., Bebout, G.E. and Fralick, P.W., 2013. Stability of the nitrogen cycle during development of sulfidic water in the redox-stratified late Paleoproterozoic ocean. Geology, 41(6): 655-658.

Goldblatt, C., Claire, M.W., Lenton, T.M., Matthews, A.J., Watson, A.J. and Zahnle, K.J., 2009. Nitrogen-enhanced greenhouse warming on early Earth. Nature Geoscience, 2(12): 891896.

Granger, J., Prokopenko, M.G., Sigman, D.M., Mordy, C.W., Morse, Z.M., Morales, L.V., Sambrotto, R.N. and Plessen, B., 2011. Coupled nitrification-denitrification in sediment of the eastern Bering Sea shelf leads to $15 \mathrm{~N}$ enrichment of fixed $\mathrm{N}$ in shelf waters. Journal of Geophysical Research, 116: doi: 10.1029/2010JC006751.

Granger, J. and Ward, B.B., 2003. Accumulation of nitrogen oxides in copper-limited cultures of denitrifying bacteria. Limnology and Oceanography, 48: 313-318.

Gregory, D.D., Large, R.R., Halpin, J.A., Steadman, J.A., Hickman, A.H., Ireland, T.R. and Holden, P., 2015. The chemical conditions of the late Archean Hamersley basin inferred from whole rock and pyrite geochemistry with $\Delta^{33} \mathrm{~S}$ and $\delta^{34} \mathrm{~S}$ isotope analyses. Geochimica et Cosmochimica Acta, 149: 223-250.

Griffin, B.M., Schott, J. and Schink, B., 2007. Nitrite, an electron donor for anoxygenic photosynthesis. Science, 316(5833): 1870-1870.

Grotzinger, J.P. and Kasting, J.F., 1993. New constraints on Precambrian ocean composition. The Journal of Geology, 101: 235-243. 
1406

1407

1408

1409

1410

1411

1412

1413

1414

1415

1416

1417

1418

1419

1420

1421

1422

1423

1424

1425

1426

1427

1428

1429

1430

1431

1432

1433

1434

1435

1436

1437

1438

1439

1440

1441

1442

1443

1444

1445

1446

1447

1448

1449

1450

Guy, B.M., Ono, S., Gutzmer, J., Kaufman, A.J., Lin, Y., Fogel, M.L. and Beukes, N.J., 2012. A multiple sulfur and organic carbon isotope record from non-conglomeratic sedimentary rocks of the Mesoarchean Witwatersrand Supergroup, South Africa. Precambrian Research, 216-219: 208-231.

Habicht, K.S., Gade, M., Thamdrup, B., Berg, P. and Canfield, D.E., 2002. Calibration of sulfate levels in the Archean Ocean. Science, 298: 2372-2374.

Haendel, D., Muehle, K., Nitzsche, H.-M., Stiehl, G. and Wand, U., 1986. Isotopic variations of the fixed nitrogen in metamorphic rocks. Geochimica et Cosmochimica Acta, 50: 749758.

Haltia, T., Brown, K., Tegoni, M., Cambillau, C., Saraste, M., Mattila, K. and Djinovic-Carugo, K., 2003. Crystal structure of nitrous oxide reductase from Paracoccus denitrificans at 1.6 A resolution. Biochemical Journal, 369: 77-88.

Hardisty, D.S., Lu, Z., Planavsky, N.J., Bekker, A., Philippot, P., Zhou, X. and Lyons, T.W., 2014. An iodine record of Paleoproterozoic surface ocean oxygenation. Geology, 42(7): 619-622.

Henderson-Sellers, A. and Schwartz, A.W., 1980. Chemical evolution and ammonia in the early Earth's atmosphere. Nature, 287(5782): 526-528.

Henry, R.B.C., Edmunds, M.G. and Köppen, J., 2000. On the Cosmic Origins of Carbon and Nitrogen. The Astrophysical Journal, 541: 660-674.

Higgins, M.B., Robinson, R.S., Carter, S.J. and Pearson, A., 2010. Evidence from chlorin nitrogen isotopes for alternating nutrient regimes in the Eastern Mediterranean Sea. Earth and Planetary Science Letters, 290(1): 102-107.

Higgins, M.B., Robinson, R.S., Husson, J.M., Carter, S.J. and Pearson, A., 2012. Dominant eukaryotic export production during ocean anoxic events reflects the importance of recycled $\mathrm{NH}_{4}^{+}$. Proceedings of the National Academy of Sciences, 109(7): 2269-2274.

Hoch, M.P., Fogel, M.L. and Kirchman, D.L., 1992. Isotope fractionation associated with ammonium uptake by a marine bacterium. Limnology and Oceanography, 37(7): 14471459.

Hoffman, B.M., Lukoyanov, D., Yang, Z.Y., Dean, D.R. and Seefeldt, L.C., 2014. Mechanism of nitrogen fixation by nitrogenase: the next stage. Chemical Reviews, 114(8): 4041-4062.

Hoffman, P.F., Kaufman, A.J., Halverson, G.P. and Schrag, D.P., 1998. A Neoproterozoic snowball earth. Science, 281(5381): 1342-1346.

Hulth, S., Aller, R.C. and Gilbert, F., 1999. Coupled anoxic nitrification/manganese reduction in marine sediments. Geochimica et Cosmochimica Acta, 63(1): 49-66.

Isley, A.E. and Abbott, D.H., 1999. Plume-related mafic volcanism and the deposition of banded iron formation. Journal of Geophysical Research: Solid Earth, 104(B7): 15461-15477.

Izon, G., Zerkle, A.L., Zhelezinskaia, I., Farquhar, J., Newton, R.J., Poulton, S.W., Eigenbrode, J.L. and Claire, M.W., 2015. Multiple oscillations in Neoarchaean atmospheric chemistry. Earth and Planetary Science Letters, 431: 264-273.

Jacquot, J.E., Kondo, Y., Knapp, A.N. and Moffett, J.W., 2013. The speciation of copper across active gradients in nitrogen - cycle processes in the eastern tropical South Pacific. Limnology and Oceanography, 58(4): 1387-1394.

Jia, Y., 2006. Nitrogen isotope fractionations during progressive metamorphism: a case study from the Paleozoic Cooma metasedimentary complex, southeastern Australia. Geochimica et Cosmochimica Acta, 70: 5201-5214. 
1451

1452

1453

1454

1455

1456

1457

1458

1459

1460

1461

1462

1463

1464

1465

1466

1467

1468

1469

1470

1471

1472

1473

1474

1475

1476

1477

1478

1479

1480

1481

1482

1483

1484

1485

1486

1487

1488

1489

1490

1491

1492

1493

1494

Jia, Y. and Kerrich, R., 2004. Nitrogen 15-enriched Precambrian kerogen and hydrothermal systems. Geochemistry Geophysics Geosystems, 5(7): doi: 10.1029/2004GC000716.

Johnson, B. and Goldblatt, C., 2015. The Nitrogen budget of Earth. Earth-Science Reviews, 148: 150-173.

Johnson, J.E., Gerpheide, A., Lamb, M.P. and Fischer, W.W., 2014. $\mathrm{O}_{2}$ constraints from Paleoproterozoic detrital pyrite and uraninite. Geological Society of America Bulletin, doi: 10.1130/B30949.1.

Johnston, D.T., Poulton, S.W., Goldberg, T., Sergeev, V.N.P., V., Vorob'eva, N.G., Bekker, A. and Knoll, A.H., 2012. Late Ediacaran redox stability and metazoan evolution. Earth and Planetary Science Letters, 335: 25-35.

Johnston, D.T., Poulton, S.W., Tosca, N.J., O'Brien, T., Halverson, G.P., Schrag, D.P. and Macdonald, F.A., 2013. Searching for an oxygenation event in the fossiliferous Ediacaran of northwestern Canada. Chemical Geology, 362: 273-286.

Junium, C.K. and Arthur, M.A., 2007. Nitrogen cycling during the Cretaceous, CenomanianTuronian Oceanic Anoxic Event II. Geochemistry Geophysics Geosystems, 8(3): doi: 10.1029/2006GC001328.

Kah, L.C. and Bartley, J.K., 2011. Protracted oxygenation of the Proterozoic biosphere. International Geology Review, 53(11-12): 1424-1442.

Kah, L.C., Lyons, T.W. and Frank, T.D., 2004. Low marine sulphate and protracted oxygenation of the Proterozoic biosphere. Nature, 431: 834-838.

Kalvelage, T., Lavik, G., Lam, P., Contreras, S., Arteaga, L., Löscher, C.R., Oschlies, A., Paulmier, A., Stramma, L. and Kuypers, M.M., 2013. Nitrogen cycling driven by organic matter export in the South Pacific oxygen minimum zone. Nature Geoscience, 6(3): 228234.

Karanasios, K.A., Vasiliadou, I.A., Pavlou, S. and Vayenas, D.V., 2010. Hydrogenotrophic denitrification of potable water: a review. Journal of Hazardous Materials, 180(1): 20-37.

Kartal, B., Kuypers, M.M., Lavik, G., Schalk, J., Op den Camp, H.J., Jetten, M.S. and Strous, M., 2007. Anammox bacteria disguised as denitrifiers: nitrate reduction to dinitrogen gas via nitrite and ammonium. Environmental Microbiology, 9(3): 635-642.

Kasting, J.F., 1990. Bolide impacts and the oxidation state of carbon in the Earth's early atmosphere. Origins of Life and Evolution of the Biosphere, 20(3-4): 199-231.

Kasting, J.F. and Siefert, J.L., 2001. Biogeochemistry: the nitrogen fix. Nature, 412(6842): 26-27.

Kasting, J.F. and Walker, J.C., 1981. Limits on oxygen concentration in the prebiological atmosphere and the rate of abiotic fixation of nitrogen. Journal of Geophysical Research: Oceans, 86(C2): 1147-1158.

Kavanagh, L. and Goldblatt, C., 2015. Using raindrops to constrain past atmospheric density. Earth and Planetary Science Letters, 413: 51-58.

Kendall, B., Creaser, R.A., Gordon, G.W. and Anbar, A., 2009. Re-Os and Mo isotope systematics of black shales from the middle Proterozoic Velkerri and Wollogoran formations, McArthur basin, northern Australia. Geochimica et Cosmochimica Acta, 73: 2534-2558.

Kendall, B., Creaser, R.A., Reinhard, C.T., Lyons, T.W. and Anbar, A.D., 2015a. Transient episodes of mild environmental oxygenation and oxidative continental weathering during the late Archean. Science Advances, 1(10): DOI: 10.1126/sciadv.1500777 
1495

Kendall, B., Gordon, G.W., Poulton, S.W. and Anbar, A.D., 2011. Molybdenum isotope constraints on the extent of late Paleoproterozoic ocean euxinia. Earth and Planetary Science Letters, 307(3): 450-460.

Kendall, B., Komiya, T., Lyons, T.W., Bates, S.M., Gordon, G.W., Romaniello, S.J., Jiang, G., Creaser, R.A., Xiao, S., McFadden, K., Sawaki, Y., Tahata, M., Shu, D., Han, J., Li, Y., Chu, X. and Anbar, A.D., 2015b. Uranium and molybdenum isotope evidence for an episode of widespread ocean oxygenation during the late Ediacaran Period. Geochimica et Cosmochimica Acta, 156: 173-193.

Kendall, B., Reinhard, C.T., Lyons, T.W., Kaufman, A.J., Poulton, S.W. and Anbar, A., 2010. Pervasive oxygenation along late Archaean ocean margins. Nature Geoscience, 3: 647652.

Kessler, A.J., Bristow, L.A., Cardenas, M.B., Glud, R.N., Thamdrup, B. and Cook, P.L., 2014. The isotope effect of denitrification in permeable sediments. Geochimica et Cosmochimica Acta, 133: 156-167.

Kikumoto, R., Tahata, M., Nishizawa, M., Sawaki, Y., Maruyama, S., Shu, D., Han, J., Komiya, T., Takai, K. and Ueno, Y., 2014. Nitrogen isotope chemostratigraphy of the Ediacaran and Early Cambrian platform sequence at Three Gorges, South China. Gondwana Research, 25(3): 1057-1069.

Kite, E.S., Williams, J.P., Lucas, A. and Aharonson, O., 2014. Low palaeopressure of the martian atmosphere estimated from the size distribution of ancient craters. Nature Geoscience, , 7(5): 335-339.

Knoll, A.H., Javaux, E.J., Hewitt, D. and Cohen, P., 2006. Eukaryotic organisms in Proterozoic oceans. Philosophical Transactions of the Royal Society of London B, 361: 1023-1038.

Koehler, M.C., Stüeken, E.E., Kipp, M.A., Buick, R. and Knoll, A.H., in review. Spatial and temporal trends in Precambrian nitrogen cycling: a Mesoproterozoic offshore nitrate minimum.

Krissansen-Totton, J., Buick, R. and Catling, D.C., 2015. A statistical analysis of the carbon isotope record from the Archean to Phanerozoic and implications for the rise of oxygen. American Journal of Science, 315(4): 275-316.

Kritee, K., Sigman, D.M., Granger, J., Ward, B.B., Jayakumar, A. and Deutsch, C., 2012. Reduced isotope fractionation by denitrification under conditions relevant to the ocean. Geochimica et Cosmochimica Acta, 92: 243-259.

Kuga, M., Carrasco, N., Marty, B., Marrocchi, Y., Bernard, S., Rigaudier, T., Fleury, B. and Tissandier, L., 2014. Nitrogen isotopic fractionation during abiotic synthesis of organic solid particles. Earth and Planetary Science Letters, 393: 2-13.

Kuhn, W.R. and Atreya, S.K., 1979. Ammonia photolysis and the greenhouse effect in the primordial atmosphere of the Earth. Icarus, 37(1): 207-213.

Kump, L.R., Junium, C., Arthur, M.A., Brasier, A., Fallick, A., Melezhik, V., Lepland, A., CČrne, A.E. and Luo, G., 2011. Isotopic evidence for massive oxidation of organic matter following the Great Oxidation Event. Science, 334(6063): 1694-1696.

Kurzweil, F., Claire, M.W., Thomazo, C., Peters, M., Hannington, M. and Strauss, H., 2013. Atmospheric sulfur rearrangement 2.7 billion years ago: Evidence for oxygenic photosynthesis. Earth and Planetary Science Letters, 366: 17-26.

Kurzweil, F., Wille, M., Schoenberg, R., Taubald, H. and van Kranendonk, M.J., 2015. Continuously increasing $\delta^{98}$ Mo values in Neoarchean black shales and iron formations from the Hamersley Basin. Geochimica et Cosmochimica Acta, 164: 523-542. 
Lalonde, S.V. and Konhauser, K.O., 2015. Benthic perspective on Earth's oldest evidence for oxygenic photosynthesis. Proceedings of the National Academy of Sciences, 112(4): 9951000.

Lam, P., Lavik, G., Jensen, M.M., van de Vossenberg, J., Schmid, M., Woebken, D., Gutierrez, D., Amann, R., Jetten, M.S.M. and Kuypers, M.M.M., 2009. Revising the nitrogen cycle in the Peruvian oxygen minimum zone. Proceedings of the National Academy of Sciences, 106: 4752-4757.

LaPorte, D.F., Holmden, C., Patterson, W.P., Loxton, J.D., Melchin, M.J., Mitchell, C.E., Finney, S.C. and Sheets, H.D., 2009. Local and global perspectives on carbon and nitrogen cycling during the Hirnantian glaciation. Palaeogeography Palaeoclimatology Palaeoecology, 276: 182-195.

Lehman, M.R., Bernasconi, S.M., Barbieri, A. and McKenzie, J.A., 2002. Preservation of organic matter and alteration of its carbon and nitrogen isotope composition during simulated and in situ early sedimentary diagenesis. Geochimica et Cosmochimica Acta, 66(20): 3573-3584.

Lenton, T.M., Boyle, R.A., Poulton, S.W., Shields-Zhou, G.A. and Butterfield, N.J., 2014. Coevolution of eukaryotes and ocean oxygenation in the Neoproterozoic era. Nature Geoscience, 7(4): 257-265.

Li, L., Sherwood Lollar, B., Li, H., Wortmann, U.G. and Lacrampe-Couloume, G., 2012. Ammonium stability and nitrogen isotope fractionations for $\mathrm{NH}_{4}{ }^{+}-\mathrm{NH}_{3(\mathrm{aq})}-\mathrm{NH}_{3 \text { (gas) }}$ systems at $20-70^{\circ} \mathrm{C}$ and $\mathrm{pH}$ of 2-13: applications to habitability and nitrogen cycling in low-temperature hydrothermal systems. Geochimica et Cosmochimica Acta, 84: 280-296.

Li, L., Zheng, Y.F., Cartigny, P. and Li, J., 2014. Anomalous nitrogen isotopes in ultrahighpressure metamorphic rocks from the Sulu orogenic belt: Effect of abiotic nitrogen reduction during fluid-rock interaction. Earth and Planetary Science Letters, 403: 67-78.

Liang, M.C., Heays, A.N., Lewis, B.R., Gibson, S.T. and Yung, Y.L., 2007. Source of nitrogen isotope anomaly in $\mathrm{HCN}$ in the atmosphere of Titan. The Astrophysical Journal Letters, 664(2): doi: 10.1086/520881.

Liermann, L.J., Guynn, R.L., Anbar, A. and Brantley, S.L., 2005. Production of a molybdophore during metal-targeted dissolution of silicates by soil bacteria. Chemical Geology, 220(3): 285-302.

Lilley, M.D., Butterfield, D.A., Olson, E.J., Lupton, J.E., Macko, S.A. and McDuff, R.E., 1993. Anomalous $\mathrm{CH} 4$ and $\mathrm{NH} 4+$ concentrations at an unsedimented mid-ocean-ridge hydrothermal system. Nature, 364(6432): 45-47.

Little, S.H., Vance, D., Lyons, T.W. and McManus, J., 2015. Controls on trace metal authigenic enrichment in reducing sediments: Insights from modern oxygen-deficient settings. American Journal of Science, 315(2): 77-119.

Luo, G., Algeo, T.J., Zhan, R., Yan, D., Huang, J., Liu, J. and Xie, S., 2015. Perturbation of the marine nitrogen cycle during the Late Ordovician glaciation and mass extinction. Palaeogeography, Palaeoclimatology, Palaeoecology: doi:10.1016/j.palaeo.2015.07.018. Luo, G., Junium, C.K., Kump, L.R., Huang, J., Li, C., Feng, Q., Shi, X., Bai, X. and Xie, S., 2014a. Shallow stratification prevailed for 1700 to 1300 Ma ocean: Evidence from organic carbon isotopes in the North China Craton. Earth and Planetary Science Letters, 400: 219-232. 
Luo, G., Ono, S., Beukes, N.J., Wang, D.T., Xie, S. and Summons, R.E., 2016. Rapid oxygenation of Earth's atmosphere 2.33 billion years ago. Science Advances, 2(5): doi: 10.1125/sciadv.1600134.

Luo, G., Ono, S., Huang, J., Algeo, T.J., Li, C., Zhou, L., Robinson, A., Lyons, T.W. and Xie, S., 2014b. Decline in oceanic sulfate levels during the early Mesoproterozoic. Precambrian Research.

Luther, G.W., Sundby, B., Lewis, B.L., Brendel, P.J. and Silverberg, N., 1997. Interactions of manganese with the nitrogen cycle: alternative pathways to dinitrogen. Geochimica et Cosmochimica Acta, 61(19): 4043-4052.

Lyons, T.W., Reinhard, C.T. and Planavsky, N.J., 2014. The rise of oxygen in Earth's early ocean and atmosphere. Nature, 506: 307-315.

Marshall, C.R., 2006. Explaining the Cambrian "explosion" of animals. Annual Reviews in Earth and Planetary Sciences, 34: 355-384.

Martens-Habbena, W., Berube, P.M., Urakawa, H., José, R. and Stahl, D.A., 2009. Ammonia oxidation kinetics determine niche separation of nitrifying Archaea and Bacteria. Nature, 461: 976-979.

Marty, B., 2012. The origins and concentrations of water, carbon, nitrogen and noble gases on Earth. Earth and Planetary Science Letters, 313: 56-66.

Marty, B., Zimmermann, L., Pujol, M., Burgess, R. and Philippot, P., 2013. Nitrogen isotopic composition and density of the Archean atmosphere. Science, 342(6154): 101-104.

Mather, T.A., Pyle, D.M. and Allen, A.G., 2004. Volcanic source for fixed nitrogen in the early Earth's atmosphere. Geology, 32(10): 905-908.

McCready, R.G.L., Gould, W.D. and Barendregt, R.W., 1983. Nitrogen isotope fractionation during the reduction of NO3-to NH4+ by Desulfovibrio sp. Canadian Journal of Microbiology, 29(2): 231-234.

McElroy, M.B., 1983. Marine biological controls on atmospheric $\mathrm{CO}_{2}$ and climate. Nature, 302: 328-329.

McGlynn, S.E., Boyd, E.S., Peters, J.W. and Orphan, V.J., 2012. Classifying the metal dependence of uncharacterized nitrogenases. Frontiers in microbiology, 3: doi:10.3389/fmicb.2012.00419.

McManus, J., Nägler, T.F., Siebert, C., Wheat, C.G. and Hammond, D.E., 2002. Oceanic molybdenum isotope fractionation: Diagenesis and hydrothermal ridge - flank alteration. Geochemistry, Geophysics, Geosystems, 3(12): 1-9.

Mehta, M.P. and Baross, J.A., 2006. Nitrogen fixation at $92 \mathrm{C}$ by a hydrothermal vent archaeon. Science, 314(5806): 1783-1786.

Mingram, B. and Bräuer, K., 2001. Ammonium concentration and nitrogen isotope composition in metasedimentary rocks from different tectonometamorphic units of the European Variscan Belt. Geochimica et Cosmochimica Acta, 65(2): 273-287.

Moebius, J., 2013. Isotope fractionation during nitrogen remineralization (ammonification): implications for nitrogen isotope biogeochemistry. Geochimica et Cosmochimica Acta, 105: 422-432.

Moore, H., 1977. The isotopic composition of ammonia, nitrogen dioxide and nitrate in the atmosphere. Atmospheric Environment, 11(12): 1239-1243.

Moore, J.K. and Braucher, O., 2007. Observations of dissolved iron concentrations in the World Ocean: implications and constraints for ocean biogeochemical models. Biogeosciences Discussions, 4(2): 1241-1277. 
1631

1632

1633

1634

1635

1636

1637

1638

1639

1640

1641

1642

1643

1644

1645

1646

1647

1648

1649

1650

1651

1652

1653

1654

1655

1656

1657

1658

1659

1660

1661

1662

1663

1664

1665

1666

1667

1668

1669

1670

1671

1672

1673

1674

Morales, L.V., Granger, J., Chang, B.X., Prokopenko, M.G., Plessen, B., Gradinger, R. and Sigman, D.M., 2014. Elevated ${ }^{15} \mathrm{~N} /{ }^{14} \mathrm{~N}$ in particulate organic matter, zooplankton, and diatom frustule-bound nitrogen in the ice-covered water column of the Bering Sea eastern shelf. Deep Sea Research Part II: Topical Studies in Oceanography, 109: 100-111.

Mulder, A., Van de Graaf, A.A., Robertson, L.A. and Kuenen, J.G., 1995. Anaerobic ammonium oxidation discovered in a denitrifying fluidized-bed reactor. FEMS Microbiology Ecology 16(3): 177-183.

Müller, P.J., 1977. CN ratios in Pacific deep-sea sediments: Effect of inorganic ammonium and organic nitrogen compounds sorbed by clays. Geochimica et Cosmochimica Acta, 41(6): 765-776.

Narbonne, G.M., 2005. The Ediacara biota: Neoproterozoic origin of animals and their ecosystems. Annual Reviews in Earth and Planetary Sciences, 33: 421-442.

Navarro-Gonzalez, R., McKay, C.P. and Nna Mvondo, D., 2001. A possible nitrogen crisis for Archaean life due to reduced nitrogen fixation by lightning. Nature, 412: 61-64.

Navarro-González, R., Molina, M.J. and Molina, L.T., 1998. Nitrogen fixation by volcanic lightning in the early Earth. Geophysical Research Letters, 25(16): 3123-3126.

Nishizawa, M., Miyazaki, J., Makabe, A., Koba, K. and Takai, K., 2014. Physiological and isotopic characteristics of nitrogen fixation by hyperthermophilic methanogens: Key insights into nitrogen anabolism of the microbial communities in Archean hydrothermal systems. Geochimica et Cosmochimica Acta, 138: 117-135.

Nna-Mvondo, D., Navarro-González, R., Raulin, F. and Coll, P., 2005. Nitrogen fixation by corona discharge on the early Precambrian Earth. Origins of Life and Evolution of Biospheres, 35(5): 401-409.

Och, L.M. and Shields-Zhou, G.A., 2012. The Neoproterozoic oxygenation event: environmental perturbations and biogeochemical cycling. Earth-Science Reviews, 110(1): 26-57.

Ohkouchi, N., Kashiyama, Y., Kuroda, J., Ogawa, N.O. and Kitazato, H., 2006. The importance of diazotrophic cyanobacteria as primary producers during Cretaceous Oceanic Anoxic Event 2. Biogeosciences, 3: 467-478.

Olson, S.L., Kump, L.R. and Kasting, J.F., 2013. Quantifying the areal extent and dissolved oxygen concentrations of Archean oxygen oases. Chemical Geology, 362: 35-43.

Özsoy, E. and Ünlüata, Ü., 1997. Oceanography of the Black Sea: a review of some recent results. Earth Science Reviews, 42(4): 231-272.

Palya, A.P., Buick, I.S. and Bebout, G.E., 2011. Storage and mobility of nitrogen in the continental crust: Evidence from partially melted metasedimentary rocks, Mt. Stafford, Australia. Chemical Geology, 281(3): 211-226.

Papineau, D., Mojzsis, S.J., Karhu, J.A. and Marty, B., 2005. Nitrogen isotopic composition of ammoniated phyllosilicates: case studies from Precambrian metamorphosed sedimentary rocks. Chemical Geology, 216(1): 37-58.

Papineau, D., Purohit, R., Fogel, M.L. and Shields-Zhou, G.A., 2013. High phosphate availability as a possible cause for massive cyanobacterial production of oxygen in the Paleoproterozoic atmosphere. Earth and Planetary Science Letters, 362: 225-236.

Papineau, D., Purohit, R., Goldberg, T., Pi, D., Shields, G.A., Bhu, H., Steele, A. and Fogel, M.L., 2009. High primary productivity and nitrogen cycling after the Paleoproterozoic phosphogenic event in the Aravalli Supergroup, India. Precambrian Research, 171: 37-56. 
1675

1676

1677

1678

1679

1680

1681

1682

1683

1684

1685

1686

1687

1688

1689

1690

1691

1692

1693

1694

1695

1696

1697

1698

1699

1700

1701

1702

1703

1704

1705

1706

1707

1708

1709

1710

1711

1712

1713

1714

1715

1716

1717

1718

1719

1720

Partin, C.A., Bekker, A., Planavsky, N.J. and Lyons, T.W., 2015. Euxinic conditions recorded in the ca. $1.93 \mathrm{Ga}$ Bravo Lake Formation, Nunavut (Canada): Implications for oceanic redox evolution. Chemical Geology, 417: 148-162.

Partin, C.A., Lalonde, S.V., Planavsky, N.J., Bekker, A., Rouxel, O.J., Lyons, T.W. and Konhauser, K.O., 2013. Uranium in iron formations and the rise of atmospheric oxygen. Chemical Geology, 362: 82-90.

Pavlov, A.A. and Kasting, J.F., 2002. Mass-independent fractionation of sulfur isotopes in Archean sediments: strong evidence for an anoxic Archean atmosphere. Astrobiology, 2(1): 27-41.

Pennock, J.R., Velinsky, D.J., Ludlam, J.M., Sharp, J.H. and Fogel, M.L., 1996. Isotopic fractionation of ammonium and nitrate during uptake by Skeletonema costatum: Implications for $\delta^{15} \mathrm{~N}$ dynamics under bloom conditions. Limnology and Oceanography, 41(3): 451-459.

Pinti, D.L., Hashizume, K. and Matsuda, J.I., 2001. Nitrogen and argon signatures in 3.8 to 2.8 Ga metasediments: Clues on the chemical state of the Archean ocean and the deep biosphere. Geochimica et Cosmochimica Acta, 65(14): 2301-2315.

Pinti, D.L., Hashizume, K., Sugihara, A., Massault, M. and Philippot, P., 2009. Isotopic fractionation of nitrogen and carbon in Paleoarchean cherts from Pilbara craton, Western Australia: Origin of 15N-depleted nitrogen. Geochimica et Cosmochimica Acta, 2009: 3819-3848.

Planavsky, N.J., Asael, D., Hofmann, A., Reinhard, C.T., Lalonde, S.V., Knudsen, A., Wang, X., Ossa Ossa, F., Pecoits, E., Smith, A.J.B., Beukes, N.J., Bekker, A., Johnson, T.M., Konhauser, K., Lyons, T.W. and Rouxel, O.J., 2014a. Evidence for oxygenic photosynthesis half a billion years before the Great Oxidation Event. Nature Geoscience.

Planavsky, N.J., Bekker, A., Hofmann, A., Owens, J.D. and Lyons, T.W., 2012. Sulfur record of rising and falling marine oxygen and sulfate levels during the Lomagundi event. Proceedings of the National Academy of Sciences, 109(45): 18300-18305.

Planavsky, N.J., McGoldrick, P., Scott, C.T., Li, C., Reinhard, C.T., Kelly, A.E., Chu, X., Bekker, A., Love, G.D. and Lyons, T.W., 2011. Widespread iron-rich conditions in the mid-Proterozoic ocean. Nature, 477: 448-451.

Planavsky, N.J., Reinhard, C.T., Wang, X., Thomson, D., McGoldrick, P., Rainbird, R.H., Johnson, T., Fischer, W.W. and Lyons, T.W., 2014b. Low Mid-Proterozoic atmospheric oxygen levels and the delayed rise of animals. Science, 346(6209): 635-638.

Plessen, B., Harlov, D.E., Henry, D. and Guidotti, C.V., 2010. Ammonium loss and nitrogen isotopic fractionation in biotite as a function of metamorphic grade in metapelites from western Maine, USA. Geochimica et Cosmochimica Acta, 74: 4759-4771.

Poulton, S.W. and Canfield, D.E., 2005. Development of a sequential extraction procedure for iron: implications for iron partitioning in continentally derived particulates. Chemical Geology, 214(3): 209-221.

Poulton, S.W. and Canfield, D.E., 2011. Ferruginous conditions: a dominant feature of the ocean through Earth's history. Elements, 7: 107-112.

Poulton, S.W., Fralick, P.W. and Canfield, D.E., 2004. The transition to a sulphidic ocean $\sim 1.84$ billion years ago. Nature, 431: 173-177.

Prokopenko, M.G., Hammond, D.E., Berelson, W.M., Bernhard, J.M., Scott, L. and Douglas, R., 2006. Nitrogen cycling in the sediments of Santa Barbara basin and eastern subtropical North Pacific: nitrogen isotopes, diagenesis, and possible chemosymbiosis between two 
1721

1722

1723

1724

1725

1726

1727

1728

1729

1730

1731

1732

1733

1734

1735

1736

1737

1738

1739

1740

1741

1742

1743

1744

1745

1746

1747

1748

1749

1750

1751

1752

1753

1754

1755

1756

1757

1758

1759

1760

1761

1762

1763

1764

1765

lithotrophs (Thioploca and Anammox) - "riding on a glider". Earth and Planetary Science Letters, 242(1-2): 186-204.

Raghoebarsing, A.A., Pol, A., Van de Pas-Schoonen, K.T., Smolders, A.J., Ettwig, K.F., Rijpstra, W.I.C., Schouten, S., Sinninghe Damsté, J.S., Op den Camp, H.J.M., Jetten, M.S.M. and Strous, M., 2006. A microbial consortium couples anaerobic methane oxidation to denitrification. Nature, 440(7086): 918-921.

Raiswell, R., Buckley, F., Berner, R.A. and Anderson, T.F., 1988. Degree of pyritization of iron as a paleoenvironmental indicator of bottom-water oxygenation. Journal of Sedimentary Research, 58(5): 812-819.

Rasmussen, B. and Buick, R., 1999. Redox state of the Archean atmosphere: Evidence from detrital heavy minerals in ca. 3250-2750 Ma sandstones from the Pilbara Craton, Australia. Geology, 27(2): 115-118.

Rau, G.H., Arthur, M.A. and Dean, W.E., 1987. 15N/14N variations in Cretaceous Atlantic sedimentary sequences: implications for past changes in marine nitrogen biogeochemistry. Earth and Planetary Science Letters, 82: 269-279.

Raymond, J., Siefert, J.L., Staples, C.R. and Blankenship, R.E., 2004. The natural history of nitrogen fixation. Molecular Biology and Evolution, 21(3): 541-554.

Reinhard, C.T., Planavsky, N.J. and Lyons, T.W., 2013a. Long-term sedimentary recycling of rare sulphur isotope anomalies. Nature, 497(7447): 100-103.

Reinhard, C.T., Planavsky, N.J., Robbins, L.J., Partin, C.A., Gill, B.C., Lalonde, S.V., Bekker, A., Konhauser, K.O. and Lyons, T.W., 2013b. Proterozoic ocean redox and biogeochemical stasis. Proceedings of the National Academy of Sciences, 110(14): 53575362.

Reinhard, C.T., Raiswell, R., Scott, C.T., Anbar, A. and Lyons, T.W., 2009. A late Archean sulfidic sea stimulated by early oxidative weathering of the continents. Science, 326: 713716.

Roberson, A.L., Roadt, J., Halevy, I. and Kasting, J.F., 2011. Greenhouse warming by nitrous oxide and methane in the Proterozoic Eon. Geobiology, 9: 313-320.

Robinson, D., 2001. $\delta^{15} \mathrm{~N}$ as an integrator of the nitrogen cycle. TRENDS in Ecology \& Evolution, 16(3): 153-162.

Robinson, R.S., Kienast, M., Albuquerque, A.L., Altabet, M., Contreras, S., De Pol Holz, R., Dubois, N., Francois, R., Galbraith, E., Shu, T.-C., Ivanochko, T., Jaccard, S., Kao, S.-J., Kiefer, T., Kienast, S., Lehmann, M., Martinez, P., McCarthy, M., Moebius, J., Pedersen, T., Quan, T.M., Ryabenko, E., Schmittner, A., Schneider, R., Schneider-Mor, A., Shigemitsu, M., Sinclair, D., Somes, C., Studer, A., Thunell, R. and Yang, J.-Y., 2012. A review of nitrogen isotopic alteration in marine sediments. Paleoceanography, 27(PA4203): doi: 10.1029/2012PA002321.

Rooze, J. and Meile, C., 2016. The effect of redox conditions and bioirrigation on nitrogen isotope fractionation in marine sediments. Geochimica et Cosmochimica Acta, 184: 227239.

Rosenfeld, J.K., 1979. Ammonium adsorption in nearshore anoxic sediments. Limnology and Oceanography, 24(2): 356-364.

Rosing, M.T. and Frei, R., 2004. U-rich Archaean sea-floor sediments from Greenlandindications of $>3700$ Ma oxygenic photosynthesis. Earth and Planetary Science Letters, 217(3): 237-244. 
1766

1767

1768

1769

1770

1771

1772

1773

1774

1775

1776

1777

1778

1779

1780

1781

1782

1783

1784

1785

1786

1787

1788

1789

1790

1791

1792

1793

1794

1795

1796

1797

1798

1799

1800

1801

1802

1803

1804

1805

1806

1807

1808

1809

Rudnick, R.L. and Gao, S., 2014. Composition of the continental crust. Treatise on Geochemistry, 4: 1-51.

Sachs, J.P. and Repeta, D.J., 1999. Oligotrophy and nitrogen fixation during eastern Mediterranean sapropel events. Science, 286(5449): 2485-2488.

Sahoo, S.K., Planavsky, N.J., Kendall, B., Wang, X., Shi, X., Scott, C., Anbar, A.D., Lyons, T.W. and Jiang, G., 2012. Ocean oxygenation in the wake of the Marinoan glaciation. Nature, 489: 546-549.

Saito, M.A., Sigman, D.M. and Morel, F.M.M., 2003. The bioinorganic chemistry of the ancient ocean: the co-evolution of cyanobacterial metal requirements and biogeochemical cycles at the Archean-Proterozoic boundary? Inorganica Chimica Acta, 356: 308-318.

Sánchez-Baracaldo, P., Ridgwell, A. and Raven, J.A., 2014. A Neoproterozoic transition in the marine nitrogen cycle. Current Biology, 24(6): 652-657.

Schimmelmann, A. and Lis, G.P., 2010. Nitrogen isotopic exchange during maturation of organic matter. Organic Geochemistry, 41(1): 63-70.

Schoepfer, S.D., Henderson, C.M., Garrison, G.H. and Ward, P.D., 2012. Cessation of a productive coastal upwelling system in the Panthalassic Ocean at the Permian-Triassic Boundary. Palaeogeography, Palaeoclimatology, Palaeoecology, 313-314: 181-188.

Schoepp-Cothenet, B., Van Lis, R., Atteia, A., Baymann, F., Capowiez, L., Ducluzeau, A.-L., Duval, S., Brink, F.T., Russell, M.J. and Nitschke, W., 2012. On the universal core of bioenergetics. Biochimica et Biophysica Acta - Bioenergetics, 1827: 79-93.

Schoonen, M.A. and Xu, Y., 2001. Nitrogen reduction under hydrothermal vent conditions: Implications for the prebiotic synthesis of CHON compounds. Astrobiology, 1(2): 133142.

Schröder, S., Bekker, A., Beukes, N.J., Strauss, H. and Van Niekerk, H.S., 2008. Rise in seawater sulphate concentration associated with the Paleoproterozoic positive carbon isotope excursion: evidence from sulphate evaporites in the $~ 2.2-2.1 \mathrm{Gyr}$ shallow-marine Lucknow Formation, South Africa. Terra Nova, 20(2): 108-117.

Schröder, S. and Grotzinger, J.P., 2007. Evidence for anoxia at the Ediacaran-Cambrian boundary: the record of redox-sensitive trace elements and rare earth elements in Oman. Journal of the Geological Society, 164(1): 175-187.

Schroeder, P.A. and McLain, A.A., 1998. Illite-smectites and the influence of burial diagenesis on the geochemical cycling of nitrogen. Clay Minerals, 33(4): 539-546.

Scott, C., Lyons, T.W., Bekker, A., Shen, Y., Poulton, S.W., Chu, X. and Anbar, A.D., 2008. Tracing the stepwise oxygenation of the Proterozoic ocean. Nature, 452: 456-459.

Scott, C., Wing, B.A., Bekker, A., Planavsky, N.J., Medvedev, P., Bates, S.M., Yun, M. and Lyons, T.W., 2014. Pyrite multiple-sulfur isotope evidence for rapid expansion and contraction of the early Paleoproterozoic seawater sulfate reservoir. Earth and Planetary Science Letters, 389: 95-104.

Scott, C.T., Bekker, A., Reinhard, C.T., Schnetger, B., Krapez, B., Rumble III, D. and Lyons, T.W., 2011. Late Archean euxinic conditions before the rise of atmospheric oxygen. Geology, 39(2): 119-122.

Sephton, M.A., Amor, K., Franchi, I.A., Wignall, P.B., Newton, R. and Zonneveld, J.-P., 2002. Carbon and nitrogen isotope disturbances and an end-Norian (Late Triassic) extinction event. Geology, 30(12): 1119-1122. 
Shao, M.F., Zhang, T. and Fang, H.H.P., 2010. Sulfur-driven autotrophic denitrification: diversity, biochemistry, and engineering applications. Applied Microbiology and Biotechnology, 88(5): 1027-1042.

Shen, Y., Knoll, A.H. and Walter, M.R., 2003. Evidence for low sulphate and anoxia in a midProterozoic marine basin. Nature, 423: 632-635.

Siebert, C., Kramers, J.D., Meisel, T., Morel, P. and Naegler, T.F., 2005. PGE, Re-Os, and Mo isotope systematics in Archean and early Proterozoic sedimentary systems as proxies for redox conditions of early Earth. Geochimica et Cosmochimica Acta, 69(7): 1787-1801.

Sigman, D.M., Karsh, K.L. and Casciotti, K.L., 2009. Ocean process tracers: nitrogen isotopes in the ocean, Encyclopedia of ocean science. Elsevier, Amsterdam.

Singireddy, S., Gordon, A.D., Smirnov, A., Vance, M.A., Schoonen, M.A., Szilagyi, R.K. and Strongin, D.R., 2012. Reduction of Nitrite and Nitrate to Ammonium on Pyrite. Origins of Life and Evolution of Biospheres, 42(4): 275-294.

Smirnov, A., Hausner, D., Laffers, R., Strongin, D.R. and Schoonen, M.A., 2008. Abiotic ammonium formation in the presence of $\mathrm{Ni}-\mathrm{Fe}$ metals and alloys and its implications for the Hadean nitrogen cycle. Geochemical Transactions, 9(5): doi:10.1186/1467-4866-9-5.

Som, S.M., Buick, R., Hagadorn, J.W., Blake, T.S., Perreault, J.M., Harnmeijer, J.P. and Catling, D., 2016. Earth's air pressure 2.7 billion years ago constrained to less than half of modern levels. Nature Geoscience: DOI: 10.1038/NGEO2713.

Som, S.M., Catling, D.C., Harnmeijer, J.P., Polivka, P.M. and Buick, R., 2012. Air density 2.7 billion years ago limited to less than twice modern levels by fossil raindrop imprints. Nature, 484(7394): 359-362.

Somes, C.J., Schmittner, A., Galbraith, E.D., Lehmann, M.F., Altabet, M.A., Montoya, J.P., Letelier, R.M., Mix, A.C., Bourbonnais, A. and Eby, M., 2010. Simulating the global distribution of nitrogen isotopes in the ocean. Global Biogeochemical Cycles, 24(4): doi: 10.1029/2009GB003767.

Sørensen, J., 1978. Capacity for denitrification and reduction of nitrate to ammonia in a coastal marine sediment. Applied and Environmental Microbiology, 35(2): 301-305.

Sperling, E.A., Halverson, G.P., Knoll, A.H., Macdonald, F.A. and Johnston, D.T., 2013. A basin redox transect at the dawn of animal life. Earth and Planetary Science Letters, 371: 143-155.

Sperling, E.A., Rooney, A.D., Hays, L., Sergeev, V.N., Vorob'eva, N.G., Sergeeva, N.D., Selby, D., Johnston, D.T. and Knoll, A.H., 2014. Redox heterogeneity of subsurface waters in the Mesoproterozoic ocean. Geobiology, 12(5): 373-386.

Sperling, E.A., Wolock, C.J., Morgan, A.S., Gill, B.C., Kunzmann, M., Halverson, G.P., Macdonald, F.A., Knoll, A.H. and Johnston, D.T., 2015. Statistical analysis of iron geochemical data suggests limited late Proterozoic oxygenation. Nature, 523: 451-454.

Strous, M., Fuerst, J.A., Kramer, E.H., Logemann, S., Muyzer, G., van de Pas-Schoonen, K.T., Webb, R., Kuenen, G. and Jetten, M.S., 1999. Missing lithotroph identified as new planctomycete. Nature, 400(6743): 446-449.

Strous, M., Pelletier, E., Mangenot, S., Rattei, T., Lehner, A., Taylor, M.W., Horn, M., Daims, H., Bartol-Mavel, D., Wincker, P., Barbe, V., Fonknechten, N., Vallenet, D., Segurens, B., Schenowitz-Truong, C., Medigue, C., Collingro, A., Snel, B., Dutilh, B.E., Op den Camp, H.J.M., van der Drift, C., Cirpus, I., van den Pas-Schoonen, K.T., Harhangi, H.R., van Niftrik, L., Schmidt, M., Keltjens, J., Van de Vossenberg, J., Kartal, B., Meier, H.F., D., Huynen, M.A., Mewes, H.-W., Weissenbach, J., Jetten, M.S., Wagner, M. and Le 
1856

1857

1858

1859

1860

1861

1862

1863

1864

1865

1866

1867

1868

1869

1870

1871

1872

1873

1874

1875

1876

1877

1878

1879

1880

1881

1882

1883

1884

1885

1886

1887

1888

1889

1890

1891

1892

1893

1894

1895

1896

1897

1898

1899

1900

1901

Paslier, D., 2006. Deciphering the evolution and metabolism of an anammox bacterium from a community genome. Nature, 440(7085): 790-794.

Stuieken, E.E., 2013. A test of the nitrogen-limitation hypothesis for retarded eukaryote radiation: nitrogen isotopes across a Mesoproterozoic basinal profile. Geochimica et Cosmochimica Acta, 120: 121-139.

Stuieken, E.E., in press. Nitrogen in ancient mud: a biosignature? Astrobiology.

Stuieken, E.E., Buick, R. and Anbar, A.D., 2015a. Selenium isotopes support free $\mathrm{O}_{2}$ in the latest Archean. Geology, 43(3): 259-262.

Stüeken, E.E., Buick, R., Guy, B.M. and Koehler, M.C., 2015b. Isotopic evidence for biological nitrogen fixation by Mo-nitrogenase at 3.2 Gyr. Nature, 520: 666-669.

Stuieken, E.E., Buick, R. and Schauer, A.J., 2015c. Nitrogen isotope evidence for alkaline lakes on late Archean continents. Earth and Planetary Science Letters, 411: 1-10.

Stuieken, E.E., Catling, D.C. and Buick, R., 2012. Contributions to late Archaean sulphur cycling by life on land. Nature Geoscience, 5: 722-725.

Stüeken, E.E., Kipp, M.A., Koehler, M.C., Schwieterman, E.W., Johnson, B. and Buick, R., in review. Modeling atmospheric $\mathrm{pN} 2$ over geologic time: implications for atmospheric biosignatures. Astrobiology.

Stumm, W. and Morgan, J.J., 1996. Aquatic Chemistry. John Wiley \& Sons, Inc.

Summers, D.P. and Chang, S., 1993. Prebiotic ammonia from reduction of nitrite by iron (II) on the early Earth. Nature, 365: 630-633.

Summons, R.E., Brassell, S.C., Eglinton, G., Evans, E., Horodyski, R.J., Robinson, N. and Ward, D.M., 1988. Distinctive hydrocarbon biomarkers from fossiliferous sediment of the Late Proterozoic Walcott Member, Chuar Group, Grand Canyon, Arizona. Geochimica et Cosmochimica Acta, 52(11): 2625-2637.

Svensen, H., Bebout, G., Kronz, A., Li, L., Planke, S., Chevallier, L. and Jamtveit, B., 2008. Nitrogen gechemistry as a tracer of fluid flow in a hydrothermal vent complex in the Karoo Basin, South Africa. Geochimica et Cosmochimica Acta, 72: 4929-4947.

Sverdrup, H.U., Johnson, M.W. and Fleming, R.H., 1942. The Oceans: Their physics, chemistry, and general biology, 7. Prentice Hall, New York.

Talbot, M.R. and Johannessen, T., 1992. A high resolution palaeoclimatic record for the last 27,500 years in tropical west Africa from the carbon and nitroen isotopic composition of lacustrine organic matter. Earth and Planetary Science Letters, 110: 23-37.

Tesdal, J.E., Galbraith, E.D. and Kienast, M., 2013. Nitrogen isotopes in bulk marine sediment: linking seafloor observations with subseafloor records. Biogeosciences, 10(1): 101-118.

Thamdrup, B. and Dalsgaard, T., 2000. The fate of ammonium in anoxic manganese oxide-rich marine sediment. Geochimica et Cosmochimica Acta, 64(24): 4157-4164.

Thamdrup, B., Dalsgaard, T. and Revsbech, N.P., 2012. Widespread functional anoxia in the oxygen minimum zone of the Eastern South Pacific. Deep Sea Research Part I:

Oceanographic Research Papers, 65: 36-45.

Thomazo, C., Ader, M. and Phillippot, P., 2011. Extreme ${ }^{15} \mathrm{~N}$-enrichment in 2.72-Gyr-old sediments: evidence for a turning point in the nitrogen cycle. Geobiology, 9: 107-120.

Thomazo, C. and Papineau, D., 2013. Biogeochemical cycling of nitrogen on the early Earth. Elements, 9(5): 345-351.

Thunell, R.C., Sigman, D.M., Muller-Karger, F., Astor, Y. and Varela, R., 2004. Nitrogen isotope dynamics of the Cariaco Basin, Venezuela. Global Biogeochemical Cycles, 18(3): doi:10.1029/2003GB002185. 
1902

1903

1904

1905

1906

1907

1908

1909

1910

1911

1912

1913

1914

1915

1916

1917

1918

1919

1920

1921

1922

1923

1924

1925

1926

1927

1928

1929

1930

1931

1932

1933

1934

1935

1936

1937

1938

1939

1940

1941

1942

1943

1944

1945
Tian, F., Kasting, J.F. and Zahnle, K., 2011. Revisiting HCN formation in Earth's early atmosphere. Earth and Planetary Science Letters, 308(3): 417-423.

Ueno, Y., Yoshioka, H., Maruyama, S. and Isozaki, Y., 2004. Carbon isotopes and petrography of kerogens in $~ 3.5-\mathrm{Ga}$ hydrothermal silica dikes in the North Pole area, Western Australia. Geochimica et Cosmochimica Acta, 68(3): 573-589.

Van de Graaf, A.A., Mulder, A., de Bruijn, P., Jetten, M.S., Robertson, L.A. and Kuenen, J.G., 1995. Anaerobic oxidation of ammonium is a biologically mediated process. Applied and Environmental Microbiology, 61(4): 1246-1251.

van Zuilen, M.A., Mathew, K., Wopenka, B., Lepland, A., Marti, K. and Arrhenius, G., 2005. Nitrogen and argon isotopic signatures in graphite from the 3.8-Ga-old Isua Supracrustal Belt, Southern West Greenland. Geochimica et Cosmochimica Acta, 69(5): 1241-1252.

von Damm, K.L., 1990. Seafloor hydrothermal activity: Black smokers chemistry and chimneys. Annual Reviews in Earth and Planetary Sciences, 18: 173-204.

Wang, X., Shi, X., Tang, D. and Zhang, W., 2013. Nitrogen isotope evidence for redox variations at the Ediacaran-Cambrian transition in South China. The Journal of Geology, 121(5): 489-502.

Ward, B., 2012. The global nitrogen cycle. In: A.H. Knoll, D.E. Canfield and K.O. Konhauser (Editors), Fundamentals of Geobiology. Blackwell Publishing Ltd.

Waser, N.A.D., Harrison, P.J., Nielsen, B., Calvert, S.E. and Turpin, D.H., 1998. Nitrogen isotope fractionation during the uptake and assimilation of nitrate, nitrite, ammonium, and urea by a marine diatom. Limnology and Oceanography, 43(2): 215-224.

Weber, K.A., Achenbach, L.A. and Coates, J.D., 2006. Microorganisms pumping iron: anaerobic microbial iron oxidation and reduction. Nature Reviews Microbiology, 4(10): 752-764.

Weber, K.A., Picardal, F.W. and Roden, E.E., 2001. Microbially catalyzed nitrate-dependent oxidation of biogenic solid-phase Fe (II) compounds. Environmental Science \& Technology, 35(8): 1644-1650.

Wille, M., Kramers, J.D., Naegler, T.F., Beukes, N.J., Schroeder, S., Meisel, T., Lacassie, J.P. and Voegelin, A.R., 2007. Evidence for a gradual rise of oxygen between 2.6 and $2.5 \mathrm{Ga}$ from Mo isotopes and Re-PGE signatures in shales. Geochimica et Cosmochimica Acta, 71: 2417-2435.

Yamaguchi, K.E., 2002. Geochemistry of Archean-Paleoproterozoic black shales: the early evolution of the atmosphere, oceans, and biosphere, Pennsylvania State University, 485 pp.

Yui, T.-F., Kao, S.-J. and Wu, T.-W., 2009. Nitrogen and N-isotope variation during low-grade metamorphism of the Taiwan mountain belt. Geochemical Journal, 43: 15-27.

Zahnle, K.J., 1986. Photochemistry of methane and the formation of hydrocyanic acid (HCN) in the Earth's early atmosphere. Journal of Geophysical Research: Atmospheres, 91(D2): 2819-2834.

Zerkle, A., Junium, C.K., Canfield, D.E. and House, C.H., 2008. Production of ${ }^{15} \mathrm{~N}$-depleted biomass during cyanobacterial $\mathrm{N}_{2}$-fixation at high Fe concentrations. Journal of Geophysical Research, 113: doi: 10.1029/2007JG000651.

Zerkle, A.L., Claire, M.W., Domagal-Goldman, S.D., Farquhar, J. and Poulton, S.W., 2012. A bistable organic-rich atmosphere on the Neoarchaean Earth. Nature Geoscience, 5: 359363. 
1946 Zerkle, A.L., House, C.H., Cox, R.P. and Canfield, D.E., 2006. Metal limitation of 1947 cyanobacterial N2 fixation and implications for the Precambrian nitrogen cycle. $1948 \quad$ Geobiology, 4(4): 285-297.

1949 Zhang, X., Sigman, D.M., Morel, F.M. and Kraepiel, A.M., 2014. Nitrogen isotope fractionation 1950 by alternative nitrogenases and past ocean anoxia. Proceedings of the National Academy 1951 1952 of Sciences, 111(13): 4782-4787. 


\begin{abstract}
Nitrogen is an essential nutrient for all life on Earth and it acts as a major control on biological productivity in the modern ocean. Accurate reconstructions of the evolution of life over the course of the last four billion years therefore demand a better understanding of nitrogen bioavailability and speciation through time. The biogeochemical nitrogen cycle has evidently been closely tied to the redox state of the ocean and atmosphere. Multiple lines of evidence indicate that the Earth's surface has passed in a non-linear fashion from an anoxic state in the Hadean to an oxic state in the later Phanerozoic. It is therefore likely that the nitrogen cycle has changed markedly over time, with potentially severe implications for the productivity and evolution of the biosphere. Here we compile nitrogen isotope data from the literature and review our current understanding of the evolution of the nitrogen cycle, with particular emphasis on the Precambrian. Combined with recent work on redox conditions, trace metal availability, sulfur and iron cycling on the early Earth, we then use the nitrogen isotope record as a platform to test existing and new hypotheses about biogeochemical pathways that may have controlled nitrogen availability through time. Among other things, we conclude that (a) abiotic nitrogen sources were likely insufficient to sustain a large biosphere, thus favoring an early origin of biological $\mathrm{N}_{2}$ fixation, (b) evidence of nitrate in the Neoarchean and Paleoproterozoic confirm current views of increasing surface oxygen levels at those times, (c) abundant ferrous iron and sulfide in the midPrecambrian ocean may have affected the speciation and size of the fixed nitrogen reservoir, and (d) nitrate availability alone was not a major driver of eukaryotic evolution.
\end{abstract}

